\title{
THE EXCAVATION OF NON BAN JAK, NORTHEAST THAILAND - A REPORT ON THE FIRST THREE SEASONS
}

\author{
Charles Higham ${ }^{1}$, Judith Cameron ${ }^{2}$, Nigel Chang ${ }^{3}$, Cristina Castillo ${ }^{4}$, Sian Halcrow ${ }^{5}$, Dougald \\ $\mathrm{O}^{\prime}$ Reilly ${ }^{6}$, Fiona Petchey ${ }^{7}$ and Louise Shewan ${ }^{8}$ \\ ${ }^{1}$ Department of Anthropology and Archaeology, University of Otago, charles.higham@otago.ac.nz \\ ${ }^{2}$ School of History, Culture and Language, Australian National University, judith.cameron@anu.edu.au \\ ${ }^{3}$ School of Arts \& Social Sciences, James Cook University, nigel.chang@gmail.com \\ ${ }^{4}$ Institute of Archaeology, University College, London, criscastillo@mac.com \\ ${ }^{5}$ Department of Department of Anatomy, Otago School of Medical Sciences, University of Otago, sian.halcrow@otago.ac.nz \\ ${ }^{6}$ School of Archaeology and Anthropology, Australian National University, dougald.oreilly@anu.edu.au \\ ${ }^{7}$ Radiocarbon Dating Laboratory, University of Waikato, fpetchey@waikato.ac.nz \\ ${ }^{8}$ Monash University, Melbourne Australia and University of Warwick, Coventry, UK, louise.shewan@monash.edu
}

\begin{abstract}
Non Ban Jak is a large, moated site located in the upper Mun Valley, Northeast Thailand. Excavations over three seasons in 2011-4 have revealed a sequence of occupation that covers the final stage of the local Iron Age. The site is enclosed by two broad moats and banks, and comprises an eastern and a western mound separated by a lower intervening area. The first season opened an 8 by 8 $m$ square on the eastern mound, while the second and third seasons uncovered part of the low terrain rising into the western mound, encompassing an area of 25 by $10 \mathrm{~m}$. The former revealed a sequence of industrial, residential and mortuary activity that involved the construction of houses, kiln firing of ceramic vessels and the interment of the dead within residences. The latter involved four phases of a late Iron Age cemetery, which again incorporated house floors and wall foundations, as well as further evidence for ceramic manufacture. The excavation sheds light on a late Iron Age town occupied at the threshold of state formation.
\end{abstract}

\section{INTRODUCTION}

Non Ban Jak is a large, moated site in Amphoe Non Sung, Nakhon Ratchasima Province. It is located at latitude $15^{\circ}$ $15^{\prime} 30.89^{\prime \prime}$ and longitude $102^{\circ} 10^{\prime} 12.99^{\prime \prime}$ (Figure 1). The mound is oval, with a maximum length of $360 \mathrm{~m}$ and width of $170 \mathrm{~m}$. Identified during a programme of site surveys in 1996, the only previous excavation involved sectioning the two moats and banks to investigate their form and date (McGrath and Boyd 2001). Eleven C14 determinations were obtained from charcoal and shell excavated from the inner and outer banks and both moats (Table 1). These indicate that the construction period falls in the $4^{\text {th }}-5^{\text {th }}$ centuries AD.

The site comprises a western and an eastern elevated mound with a depression between them. During the three seasons of excavations, an 8 by 8 metre square was opened on the eastern mound, and an area of 25 by 10 metres was excavated in an area which began in the depression and then rose onto the margin of the western mound (Figure 2).

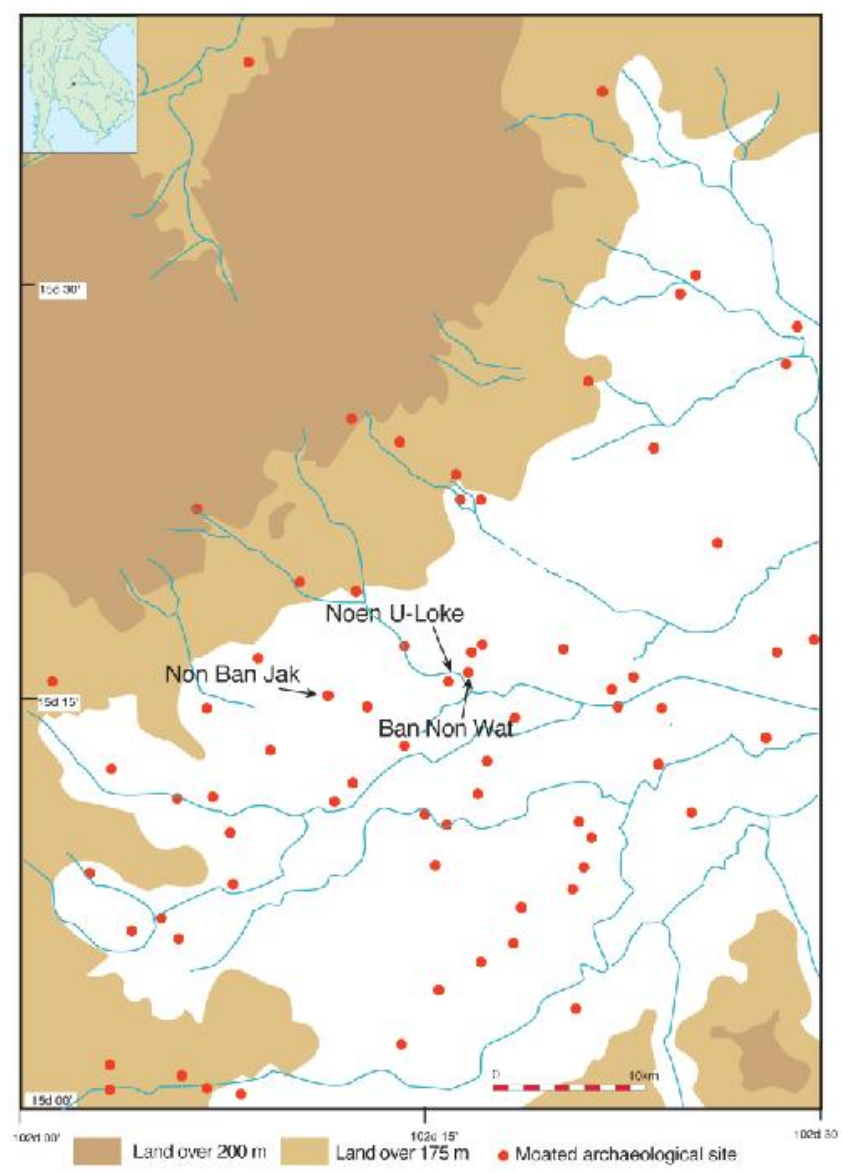

Figure 1: The upper Mun Valley study area, showing the location of the Iron Age moated sites and those mentioned in the text. 


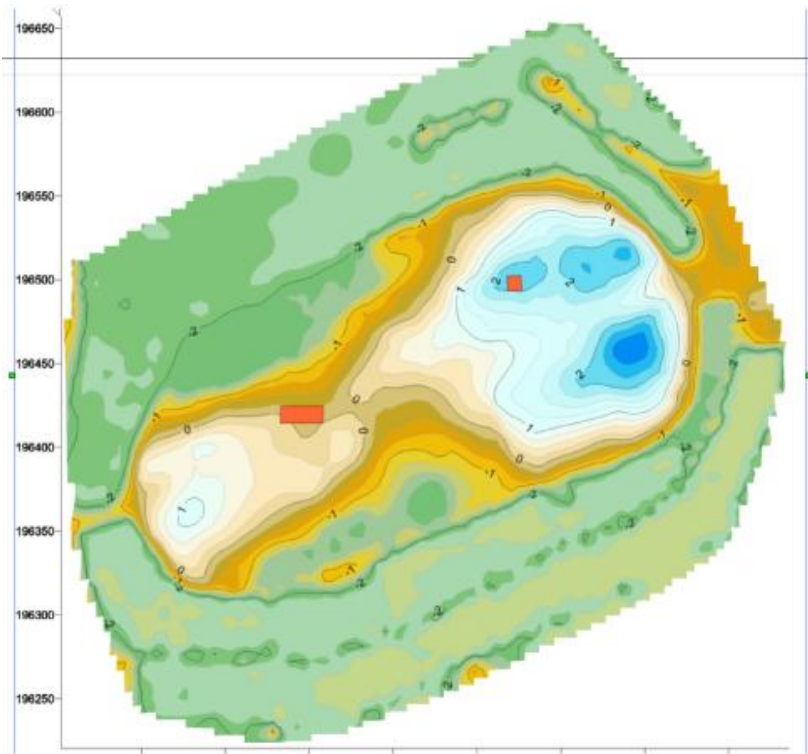

Figure 2: The plan of Non Ban Jak, showing the location of the two excavation squares. (Courtesy Dr N. Chang).

\section{THE CHRONOLOGY}

An additional 40 radiocarbon dates have been obtained during the first three seasons at Non Ban Jak (Table 2). All were calibrated using Intcal13 curves (Reimer et al. 2013) using the program OxCal v4.2 (Bronk Ramsey 2001). Those given in the text are reported at $68.2 \%$ probability.

Table 1: Radiocarbon determinations for the moats and banks.

\begin{tabular}{|c|c|c|c|c|}
\hline Location & $\begin{array}{l}\text { Lab. } \\
\text { code }\end{array}$ & Material & $\begin{array}{c}\text { C14 } \\
\text { age BP }\end{array}$ & $\begin{array}{c}\text { calibrated age (AD) } \\
68.2 \% \text { prob. }\end{array}$ \\
\hline Inner channel & Wk 6493 & charcoal & $1568 \pm 57$ & $350-530$ \\
\hline Inner channel & OZD 673 & shell & $1706 \pm 34$ & $390-540$ \\
\hline Outer channel & Wk 7149 & shell & $1575 \pm 56$ & $380-540$ \\
\hline Outer channel & OZE 202 & shell & $1690 \pm 37$ & $400-540$ \\
\hline Outer channel & OZD 672 & charcoal & $1620 \pm 32$ & $400-540$ \\
\hline Outer bank & OZE 203 & shell & modern & \\
\hline Outer bank & OZE 204 & shell & $1606 \pm 37$ & $390-540$ \\
\hline Outer bank & OZE 199 & shell & $1610 \pm 32$ & $260-400$ \\
\hline Outer bank & OZE 205 & shell & $1622 \pm 39$ & $420-550$ \\
\hline Outer bank & OZE 206 & shell & $1615 \pm 48$ & $250-390$ \\
\hline Outer bank & OZE 207 & shell & $1638 \pm 35$ & $420-550$ \\
\hline
\end{tabular}

Table 2: Radiocarbon determinations from occupation and mortuary contexts.

$\begin{array}{llllll}\text { Sample } & \text { Lab } & \text { Material } & { }^{13} \mathrm{C} & { }^{14} \mathrm{C} & \text { calibrated } \\ \text { source } & \text { code } & \text { dated } & (\% \circ) & \text { age } & \text { age (AD) } \\ & (\text { Wk- }) & & & \text { BP } & 68.2 \% \text { prob. }\end{array}$

\section{Western \\ Mound}

$\underline{\text { layer } 1}$

\begin{tabular}{|c|c|c|c|c|c|c|}
\hline $\begin{array}{l}\text { AA2 } 1 \text { surf } 2 \text {, } \\
\text { feature } 1\end{array}$ & 38887 & Filopaludina & $\begin{array}{l}-0.7 \\
0.2\end{array}$ & \pm & $\begin{array}{l}1331 \\
\pm 25\end{array}$ & $650-690$ \\
\hline $\begin{array}{l}\text { AA1 1-3/surf } \\
4, \text { feature } 1\end{array}$ & 38888 & Filopaludina & $\begin{array}{l}-2.1 \\
0.2\end{array}$ & \pm & $\begin{array}{l}1306 \\
\pm 25\end{array}$ & $660-770$ \\
\hline $\begin{array}{l}\text { BB1 } 1 \text { surf } 4, \\
\text { feature } 2\end{array}$ & 38889 & Pseudodon & $\begin{array}{l}-3.5 \\
0.2\end{array}$ & \pm & $\begin{array}{l}1571 \\
\pm 25\end{array}$ & $420-540$ \\
\hline $\begin{array}{l}\text { BB1 } 1 \text { surf } 4, \\
\text { feature } 6\end{array}$ & 38890 & Filopaludina & $\begin{array}{l}-7.1 \\
0.2\end{array}$ & \pm & $\begin{array}{l}1326 \\
\pm 25\end{array}$ & $650-760$ \\
\hline $\begin{array}{l}\text { AA2 } 1 \text { surf } 4, \\
\text { feature } 3\end{array}$ & 38891 & Pseudodon & $\begin{array}{l}-6.8 \\
0.2\end{array}$ & \pm & $\begin{array}{l}1514 \\
\pm 25\end{array}$ & $530-600$ \\
\hline $\begin{array}{l}\text { AA2 } 1 \text { surf } 4 \text {, } \\
\text { feature } 1\end{array}$ & 38892 & Filopaludina & $\begin{array}{l}-7.4 \\
0.2\end{array}$ & \pm & $\begin{array}{l}1202 \\
\pm 25\end{array}$ & $770-870$ \\
\hline $\begin{array}{l}\text { AA1 surf } 4, \\
\text { feature } 2\end{array}$ & 38893 & Filopaludina & $\begin{array}{l}-4.2 \\
0.2\end{array}$ & \pm & $\begin{array}{l}1615 \\
\pm 25\end{array}$ & $390-530$ \\
\hline $\begin{array}{l}\text { BB1 } 2 \text { surf } \\
2 A \text {, feature } 8\end{array}$ & 38894 & Filopaludina & $\begin{array}{l}-4.8 \\
0.2\end{array}$ & \pm & $\begin{array}{l}1300 \\
\pm 25\end{array}$ & $660-770$ \\
\hline layer 2 & & & & & & \\
\hline $\begin{array}{l}\text { BB1 } 2 \text { surf } \\
2 A, \\
10\end{array}$ & 38895 & Pseudodon & $\begin{array}{l}-5.9 \\
0.2\end{array}$ & \pm & $\begin{array}{l}1477 \\
\pm 25\end{array}$ & $560-620$ \\
\hline $\begin{array}{ll}\text { BB1 } 2 \text { surf } \\
2 A, & \text { feature } \\
13 & \end{array}$ & 38896 & Pseudodon & $\begin{array}{l}-6.9 \\
0.2\end{array}$ & \pm & $\begin{array}{l}1546 \\
\pm 25\end{array}$ & $430-560$ \\
\hline $\begin{array}{l}\text { BB1 } 2 \text { surf } \\
2 A \text {, feature } 4\end{array}$ & 38897 & Filopaludina & $\begin{array}{l}-3.0 \\
0.2\end{array}$ & \pm & $\begin{array}{l}1566 \\
\pm 25\end{array}$ & $420-540$ \\
\hline $\begin{array}{ll}\text { BB1 } 2 \text { surf } \\
2 A, & \text { feature } \\
12 & \end{array}$ & 38898 & Pseudodon & $\begin{array}{l}-7.9 \\
0.2\end{array}$ & \pm & $\begin{array}{l}1554 \\
\pm 25\end{array}$ & $430-550$ \\
\hline $\begin{array}{l}\text { AA1 } 1 \text { 2-3 } \\
\text { feature } 3\end{array}$ & 38899 & Filopaludina & $\begin{array}{l}-5.0 \\
0.2\end{array}$ & \pm & $\begin{array}{l}1296 \\
\pm 25\end{array}$ & $670-770$ \\
\hline $\begin{array}{l}\text { BB1 } 2 \text { surf } 4, \\
\text { feature } 1\end{array}$ & 38900 & Pseudodon & $\begin{array}{l}-2.5 \\
0.2\end{array}$ & \pm & $\begin{array}{l}1503 \\
\pm 25\end{array}$ & $540-600$ \\
\hline $\begin{array}{l}\text { BB1 } 2 \text { surf } 5, \\
\text { feature } 3\end{array}$ & 38901 & Filopaludina & $\begin{array}{l}-5.9 \\
0.2\end{array}$ & \pm & $\begin{array}{l}1584 \\
\pm 25\end{array}$ & $420-540$ \\
\hline $\begin{array}{l}\text { AA1 } 2 \text { surf } 5, \\
\text { feature } 1\end{array}$ & 38902 & Pseudodon & $\begin{array}{l}-2.7 \\
0.2\end{array}$ & \pm & $\begin{array}{l}1483 \\
\pm 25\end{array}$ & $550-610$ \\
\hline
\end{tabular}




\begin{tabular}{|c|c|c|c|c|c|c|}
\hline $\begin{array}{l}\text { Z2 } 2 \text { surf } 2, \\
\text { feature } 4\end{array}$ & 38916 & Filopaludina & $\begin{array}{l}-4.3 \\
0.2\end{array}$ & \pm & $\begin{array}{l}1517 \\
\pm 25\end{array}$ & $530-600$ \\
\hline \multicolumn{7}{|l|}{ layer 3} \\
\hline $\begin{array}{l}\text { AA2 } 3 \text { surf2, } \\
\text { feature } 1\end{array}$ & 38903 & Pila & $\begin{array}{l}-6.8 \\
0.2\end{array}$ & \pm & $\begin{array}{l}1557 \\
\pm 25\end{array}$ & $430-550$ \\
\hline $\begin{array}{l}\text { BB2 } 3 \text { surf 2, } \\
\text { feature } 7\end{array}$ & 38904 & Filopaludina & $\begin{array}{l}-7.6 \\
0.2\end{array}$ & \pm & $\begin{array}{l}1543 \\
\pm 25\end{array}$ & $430-560$ \\
\hline $\begin{array}{l}\text { AA2 } 3 \text { surf } 1 \text {, } \\
\text { feature } 8\end{array}$ & 38905 & Pseudodon & $\begin{array}{l}-5.3 \\
0.2\end{array}$ & \pm & $\begin{array}{l}1587 \\
\pm 25\end{array}$ & $420-540$ \\
\hline $\begin{array}{l}\text { AA2 } 3 \text { surf } 3 \text {, } \\
\text { feature } 3\end{array}$ & 38906 & Pseudodon & $\begin{array}{l}-5.7 \\
0.2\end{array}$ & \pm & $\begin{array}{l}1631 \\
\pm 25\end{array}$ & $380-510$ \\
\hline $\begin{array}{l}\text { AA1 } 3 \text { surf } 3 \text {, } \\
\text { feature } 5\end{array}$ & 38907 & Filopaludina & $\begin{array}{l}-1.7 \\
0.2\end{array}$ & \pm & $\begin{array}{l}1590 \\
\pm 25\end{array}$ & $420-540$ \\
\hline $\begin{array}{l}\text { AA1 } 3 \text { surf } 5 \text {, } \\
\text { feature } 3\end{array}$ & 38908 & Pseudodon & $\begin{array}{l}-7.8 \\
0.2\end{array}$ & \pm & $\begin{array}{l}1656 \\
\pm 26\end{array}$ & $350-420$ \\
\hline $\begin{array}{l}\text { AA1 } 3 \text { surf } 5 \\
\text { feature } 6\end{array}$ & 38909 & Filopaludina & $\begin{array}{l}-5.6 \\
0.2\end{array}$ & \pm & $\begin{array}{l}1583 \\
\pm 25\end{array}$ & $420-540$ \\
\hline $\begin{array}{l}\text { AA1 } 3 \text { surf } 6 \\
\text { feature } 1\end{array}$ & 38910 & Pseudodon & $\begin{array}{l}-4.0 \\
0.2\end{array}$ & \pm & $\begin{array}{l}1710 \\
\pm 25\end{array}$ & $260-390$ \\
\hline $\begin{array}{l}Z 2 \\
\text { feature } 1\end{array}$ & 38917 & Filopaludina & $\begin{array}{l}-4.8 \\
0.2\end{array}$ & \pm & $\begin{array}{l}1582 \\
\pm 25\end{array}$ & $420-540$ \\
\hline \multicolumn{7}{|l|}{ layer 4} \\
\hline $\begin{array}{l}\text { AA1 } 4 \text { surf } 1, \\
\text { feature } 2\end{array}$ & 38911 & Filopaludina & $\begin{array}{l}-3.1 \\
0.2\end{array}$ & \pm & $\begin{array}{l}1766 \\
\pm 25\end{array}$ & $230-330$ \\
\hline $\begin{array}{l}\text { AA1 } 4 \text { surf } 2 \text {, } \\
\text { feature } 1\end{array}$ & 38912 & Pila & $\begin{array}{l}-2.7 \\
0.2\end{array}$ & \pm & $\begin{array}{l}1582 \\
\pm 25\end{array}$ & $420-540$ \\
\hline $\begin{array}{l}\text { AA1 } 4 \text { surf } 4 \text {, } \\
\text { feature } 5\end{array}$ & 38913 & Pseudodon & $\begin{array}{l}-7.2 \\
0.2\end{array}$ & \pm & $\begin{array}{l}1661 \\
\pm 25\end{array}$ & $350-420$ \\
\hline $\begin{array}{l}\text { Y1 } 3 \text { surf } 3 \text {, } \\
\text { feature } 1\end{array}$ & 38918 & Pseudodon & $\begin{array}{l}-3.8 \\
0.2\end{array}$ & \pm & $\begin{array}{l}1580 \\
\pm 26\end{array}$ & $420-540$ \\
\hline \multicolumn{7}{|l|}{$\begin{array}{l}\text { Eastern } \\
\text { Mound }\end{array}$} \\
\hline $\begin{array}{l}\text { A1 } 6 \text { surf } 3 \text {, } \\
\text { feature } 1\end{array}$ & 38914 & Pseudodon & $\begin{array}{l}-6.9 \\
0.2\end{array}$ & \pm & $\begin{array}{l}1649 \\
\pm 25\end{array}$ & $350-430$ \\
\hline $\begin{array}{l}\text { B1 } 5 \text { surf } 7 \text {, } \\
\text { feature } 1\end{array}$ & $\begin{array}{l}\text { OxA- } \\
27881\end{array}$ & rice & -24.36 & & $\begin{array}{l}1579 \\
\pm 26\end{array}$ & $420-540$ \\
\hline $\begin{array}{l}A 2 \quad 5-1 A \\
\text { feature } 6\end{array}$ & $\begin{array}{l}\text { OxA- } \\
27882\end{array}$ & rice & -22.66 & & $\begin{array}{l}1624 \\
\pm 23\end{array}$ & $390-530$ \\
\hline $\begin{array}{l}\text { A1 } \\
\text { feature } 1\end{array}$ & $\begin{array}{l}\text { OxA- } \\
27883\end{array}$ & rice & -24.06 & & $\begin{array}{l}1600 \\
\pm 24\end{array}$ & $410-540$ \\
\hline
\end{tabular}

\begin{tabular}{|c|c|c|c|c|c|c|}
\hline $\begin{array}{l}\text { Weste } \\
\text { Mound } \\
\text { burials }\end{array}$ & & & & & & \\
\hline $\begin{array}{l}\text { Burial } \\
\text { MP1 }\end{array}$ & 16 & 38924 & Pseudodon & $\begin{array}{l}-7.1 \pm \\
0.2\end{array}$ & $\begin{array}{l}1605 \\
\pm 25\end{array}$ & $400-540$ \\
\hline $\begin{array}{l}\text { Burial } \\
\text { MP2 }\end{array}$ & 88 & 38920 & Pseudodon & $\begin{array}{l}-6.8 \pm \\
0.2\end{array}$ & $\begin{array}{l}1618 \\
\pm 25\end{array}$ & $390-530$ \\
\hline $\begin{array}{l}\text { Burial } \\
\text { MP2 }\end{array}$ & 85 & 38922 & Pseudodon & $\begin{array}{l}-6.8 \pm \\
0.2\end{array}$ & $\begin{array}{l}1680 \\
\pm 25\end{array}$ & $340-400$ \\
\hline $\begin{array}{l}\text { Burial } \\
\text { MP2 }\end{array}$ & 104 & 38923 & eggshell & $\begin{array}{l}-9.0 \pm \\
0.2\end{array}$ & $\begin{array}{l}1737 \\
\pm 25\end{array}$ & $250-340$ \\
\hline $\begin{array}{l}\text { Burial } \\
\text { MP3 }\end{array}$ & 49 & 38919 & Pila pesmei & $\begin{array}{l}-8.5 \pm \\
0.2\end{array}$ & $\begin{array}{l}1559 \\
\pm 25\end{array}$ & $430-550$ \\
\hline $\begin{array}{l}\text { Burial } \\
\text { MP3 }\end{array}$ & 82 & 38925 & Pseudodon & $\begin{array}{l}-7.8 \pm \\
0.2\end{array}$ & $\begin{array}{l}1688 \\
\pm 25\end{array}$ & $330-400$ \\
\hline
\end{tabular}

The radiocarbon determinations for the cultural sequence on the mound itself come from three sources. The first, involves carbonized rice from two occupation contexts in the basal part of the eastern mound, where a fire had destroyed a building. Rice grains were also dated from the rake-out of a kiln. These indicate that this part of the site was occupied in the $5^{\text {th }}$ century AD (Table 2).

The sequence in the western mound was dated using in-situ freshwater shellfish recovered from discrete middens. The stratigraphic record here was divisible into four layers (phases), with radiocarbon determinations coming from each. To refine our chronological interpretation we have utilized Bayesian statistical methods whereby ${ }^{14} \mathrm{C}$ ages are constrained by this prior stratigraphic information. The model we developed for Non Ban Jak is shown in Figure 3. It consists of a series of phases each separated by a transitional boundary (i.e., contiguous multiphase model) (Bronk Ramsey 2009a). Within this model the internal consistency of the calibrated dates has been tested using an outlier detection method that enables a probabilistic measure of the degree to which samples appear to be outliers, and then calculates an offset relative to the context within which it is found (Bronk Ramsey et al. 2010). In this instance we have used a General t-Type model with prior outlier probability of $5 \%$. This allows outliers to be either too young or too old (Bronk Ramsey 2009b) and enables us to down weigh their influence in the model.

Within the western mound sequence there were four major outliers (posterior outlier probabilities $>70 \%$ compared with the prior of $0.05 \%$, including three of $>96 \%$ which are not included in the model results $96 \%$ of the time and therefore do not influence the model) and a further two with outlier probabilities of $\sim 20 \%$ (i.e. 4 times more likely to be outliers). Three of these outliers come from Layer 1, and two of which appear to be of similar age to material in Layer 2 below suggesting intermixing 


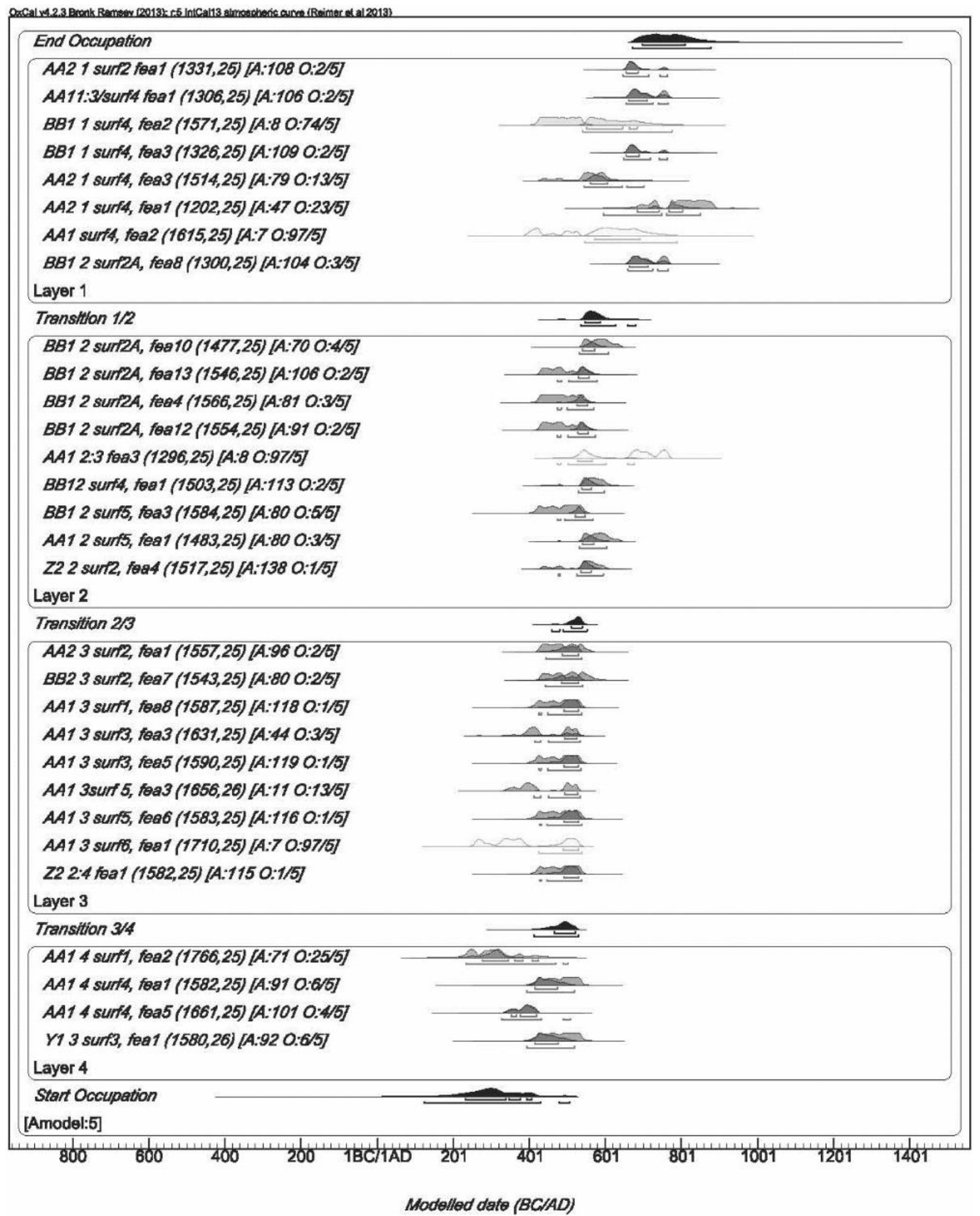

Figure 3: Bayesian age model for the Non Ban Jak sequence produced using OxCal 4.2 (Bronk Ramsey, 2001, 2009a, b). The lighter shaded distributions represent the unmodelled calibrated dates, and the darker outlines represent the results after Bayesian modelling. 


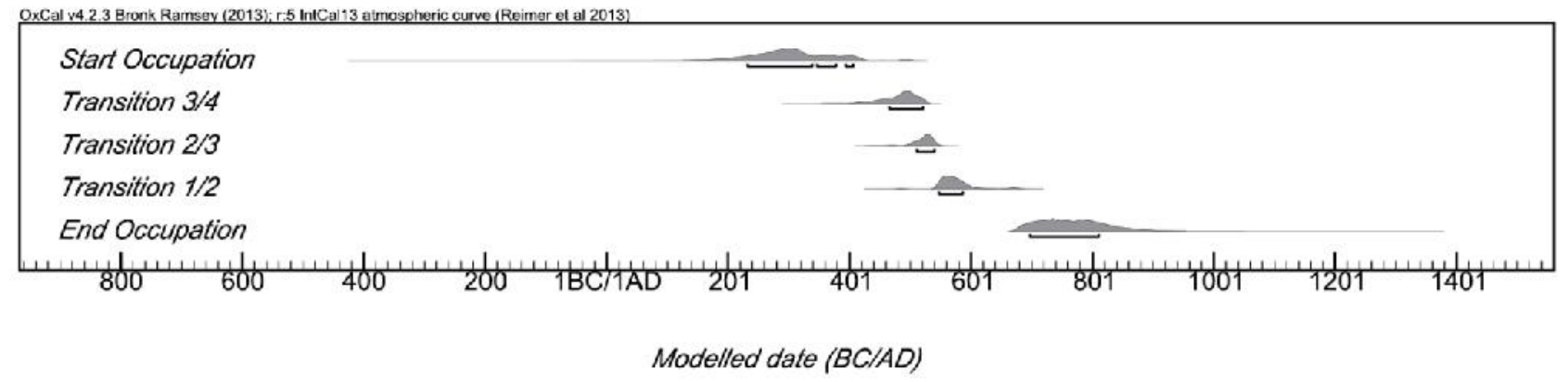

Figure 4: Summary of the transitional dates between layers.

may have occurred. Despite these outliers, the Non Ban Jak model convergence values generated by the OxCal MCMC algorithms were uniformly high (>98.4), and therefore indicate that the model is robust (low values indicate many different incompatible solutions to the model) (Bronk Ramsey 2009a). Dates for boundaries between layers are produced as part of the modeling and provide temporal constraints for each layer (Figure 4). These indicate that the initial occupation at this part of the site began in the $3^{\text {rd }}-4^{\text {th }}$ century AD (AD 220-380). The transition into layer 3 took place around AD 460-530, while the final phase of occupation ended around $\mathrm{AD}$ 700-820.

The third series of dates come from freshwater bivalves shells placed as mortuary offerings with the dead. These determinations conform to mortuary activity during the $4^{\text {th }}, 5^{\text {th }}$ and early $6^{\text {th }}$ centuries AD (Table 2) at the same time as occupation activities in the eastern and western mounds.

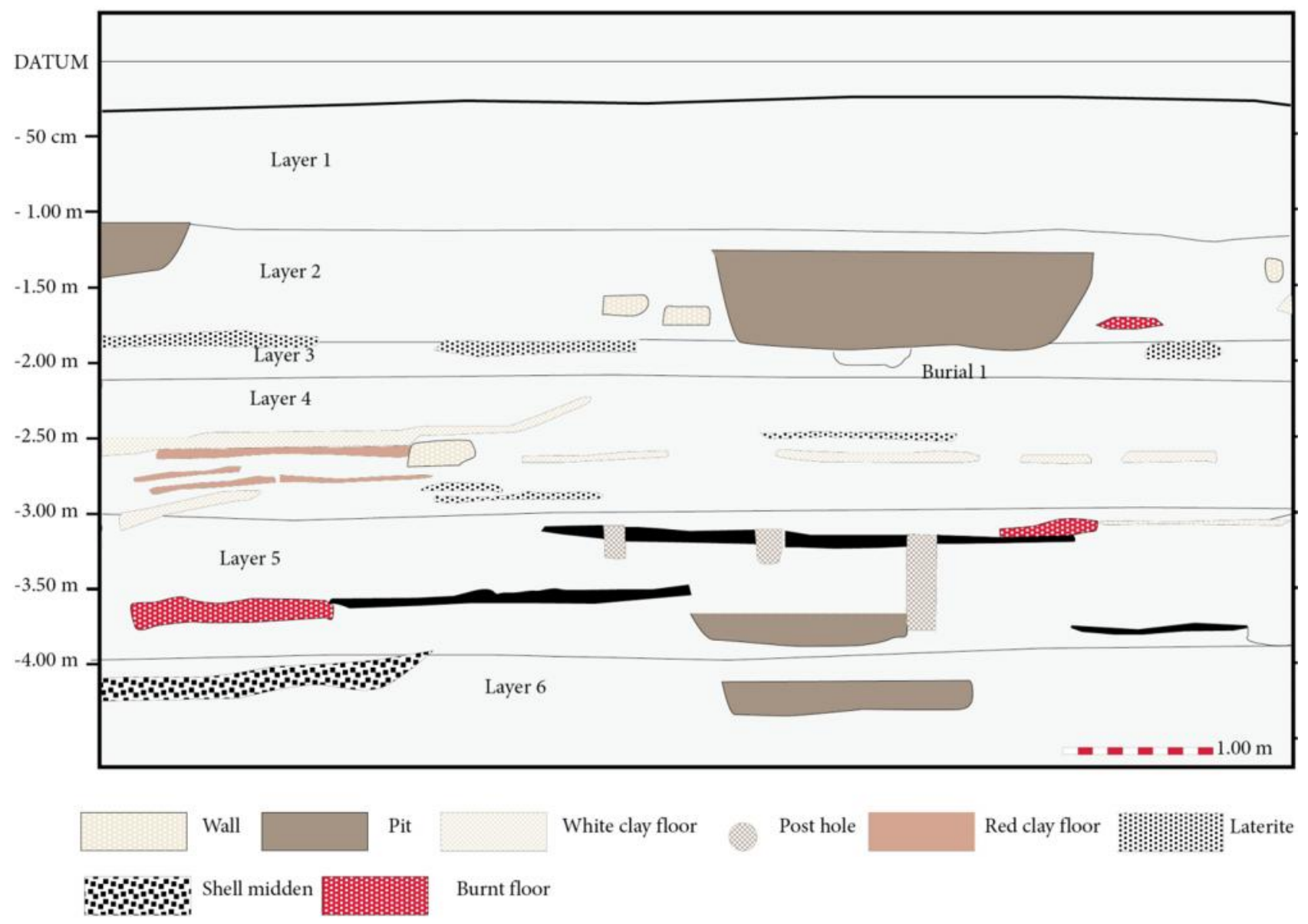

Figure 5: The north section of the eastern mound excavation. 


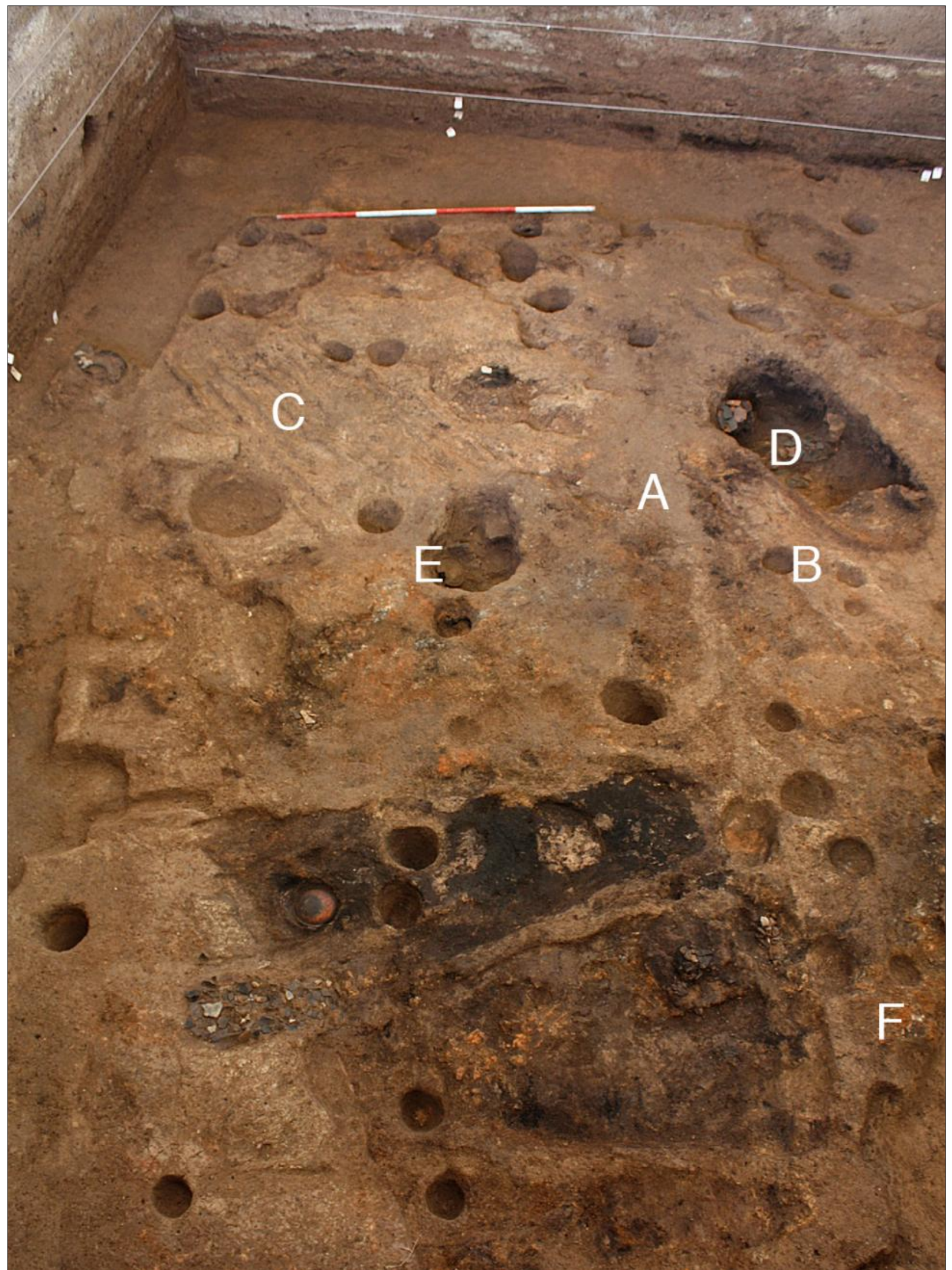

Figure 6: The surface of layer 5.2, western half of the square, showing two superimposed buildings. A is the eastern wall of the later structure. $B$ is the eastern wall of the earlier building, which was laid out on a different orientation. $C$ is the clay floor bearing what are probably bamboo impressions. $D$ is a ceramic kiln laid out on the same orientation as the earlier of the two structures. E is an infant burial cut through the floor, and $F$ is the kitchen area. In the foreground, one can see the charcoal, ash and burnt daub of the floors and collapsed walls of the earlier building. The radiocarbon dates place this structure in the $4^{\text {th }}-5^{\text {th }}$ centuries AD. 

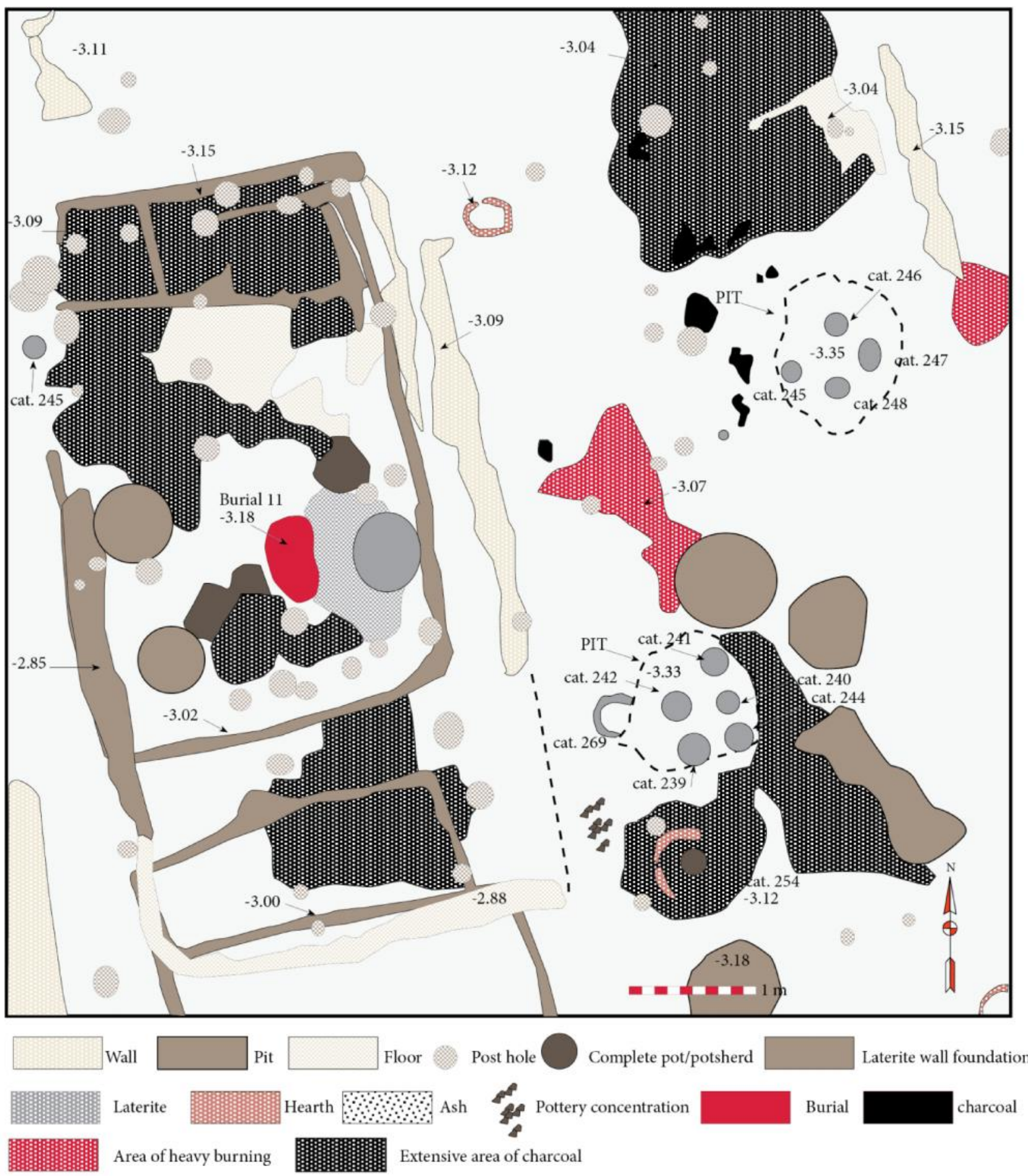

Figure 7: The surface of layer 5-1, showing the plan of a residential structure. Note the infant burial 11 cut through a floor. The internal divisions of the structure are clearly visible. The structure dates to the $4^{\text {th }}-5^{\text {th }}$ centuries $A D$.

\section{THE EASTERN MOUND}

The sequence on the eastern mound comprised six layers which reached a depth of $4.5 \mathrm{~m}$ below datum (Figure 5). The following summary of the sequence begins with the basal layer 6 and proceeds through to the last prehistoric occupation phase and the final period of occupation, which is dated to the period of the Dvaravati state on the basis of the ceramic remains. The excavation recognised six major layers, which were divided into spits approxi- mately $10 \mathrm{~cm}$ thick. Distinctive features, such as hearths, walls, floors, kilns, grave cuts, postholes and pits were assigned an unique feature number, and excavated separately to retain all finds in their cultural context. The nomenclature adopted below reflects this excavation procedure. Thus layer 6-2 refers to the second spit in layer 6, and plans are normally taken of features identified on the surface of a new spit, or of features such as house plans or burials found within a particular spit. 


\section{Layer 6}

Layer 6-1 was identified on the basis of a change in the colour to a yellow, natural-looking sandy material. However, there were many postholes cut into this layer. The base of a circular kiln for firing pottery vessels was found to have severed a lower concentration of potsherds ringed by a line of ash. This hints that there may be a second kiln beyond the area excavated.

The surface of layer 6-2 has two principal features. A deep cutting was found, originating at the edge of the kiln cut down to this context, and extending to the west. It contained faunal remains and broken potsherds, and was embedded into the natural laterite substrate and the water table. In the northwest corner of the excavated area, a concentration of occupation material was found which was again thick, and extended below the water table.

\section{Layer 5}

Layer 5 was recognized in the northeastern corner of the square on the basis of an extensive lens of dark occupation on top of a clay floor. The layer incorporated the structural remains of houses, orientated a few degrees to the west of due north, as well as the remains of two kilns for firing ceramic vessels (Figures 6-8).

The clay floor that signalled the uppermost context in layer 5 contained much charcoal, reflecting the destruction of a building in a conflagration (Figure 6). Adjacent lay a wall on an orientation about $10^{\circ}$ west of north. To the south, lay a series of pits two of which contained relatively intact Phimai Black Iron Age ceramic vessels. There was overall, much evidence for burning, including carbonised rice grains. Two radiocarbon dates derived from carbonised rice grains in this building are 390-530 and 410-540 cal. AD (Table 2). The western part of the square was dominated by the foundations of a second structure. It had clay and laterite outer walls incorporating postholes that probably supported the house walls (Figure 7). Within, a series of thin subdivisions of laterite divided the structure into rectangular areas, which are too small to have been rooms. They may have been the foundations for internal divisions that partitioned the structure. Particularly in the northern part of this building, the narrow partitions were marked by postholes which again, may have supported furniture or have acted as subdivisions. The interior contained clay or laterite floors which had been subjected to considerable heat, probably when the structure was burnt. These floors contained concentrations of carbonised rice and broken ceramic vessels. The skeleton of a rat was found adjacent to the southern exterior wall. The structure as a whole measured 3.40 by $6.40 \mathrm{~m}$, although interior partition walls proceeded south and beyond the excavation square. A laterite floor in the centre of the largest interior room sealed an oval pit that contained the infant burial 11. Since this grave also cut through an earlier laterite floor, it must date to the period when the building was in use. To the west of this building there is a clay wall foundation lying on the same orientation.
The surface of layer 5-2 contained the remains of a further building that had been destroyed by fire. This building immediately underlies that described in layer 51, but was laid out on a slightly different orientation (Figure 6). The southern part of this structure comprised clay wall foundations, within which there were thick deposits of burnt material including charred structural timber and rice grains. In the southeastern corner of the building, there was an incinerated clay floor, on which lay a pottery vessel, two hearth stones and a large quantity of carbonised rice grains. The most southerly part of this building had surviving burnt and blackened wooden foundations. Proceeding north, a thick layer of charcoal and burnt daub was found over the original clay floor. The daub incorporated the profiles of wattle supports, and this is interpreted as part of a collapsed wall overlying blackened occupation material laden with rice grains, The clay floor lips up against the edge of the walls. Burial 11, an infant, was cut through this floor as well as the collapsed wall, meaning that it could date to the building found above.

Figure 6 shows the basal remains of the structure first seen in 5-2. In the southeast corner, there is a surviving area of burnt clay floor, incorporating an upright ceramic vessel, and many carbonised rice grains. The northwest part of this building comprised a series of parallel, semicircular impressions on the clay floor, which end abruptly and in unison, as if they had reached the edge of an internal room within the building. Further clay floors, one burnt, were found at the northeastern corner of this building. There is a second structure to the east, laid out on the same orientation. This was not well preserved, although some evidence for burning is seen within the area enclosed by walls (Figure 7). Burial 10, another infant, was found within the confines of this structure.

Between these two buildings, and on the same orientation, we found an oval structure containing broken ceramic vessels and much red daub liberally tempered with rice straw, together with rice grains, ash and charcoal. On excavation, this feature turned out to have been a ceramic kiln that still contained a large pottery vessel in its base (Figure 33). The quantity of collapsed daub suggested that this kiln had been enclosed by a domed roof.

Under the buildings identified in layer 5-1/2, there was evidence for occupation in the form of dispersed hearths, areas of burning, pits and postholes. In the southeastern quadrant, a hearth was surrounded by three broken pottery vessels.

The surface of layer 5-5 has as its main feature, a straight line of charcoal in the southeastern quadrant. At the time of excavation, this was hard to interpret. However, as we probed deeper into the mound, we were to find that it represents the topmost remains of the rake out from a ceramic kiln. Other finds in this part of the site include a concentration of potsherds, and just to the north, many rice grains. Other than these finds, the layer included several postholes, some pits and an area of burning in the southwestern part of the square.

Layer 5-6 was dominated by a large concentration of burnt daub, charcoal and large pottery sherds. It is flanked 
on either side with more charcoal. At the northeastern end of this feature, there is a greater dominance of red clay daub liberally tempered with rice straw. There are several nearly complete Phimai Black pots north and south of this feature, and many large broken potsherds. Two infant jar burials flanked this concentration of daub and potsherds. As was discovered in due course, this area turned out to lie over a circular kiln for firing ceramic vessels. There is also a concentration of rice grains on this burnt area that provided a ${ }^{14} \mathrm{C}$ determination of $420-540$ cal. AD (Table 2 ). The rest of the excavated area contained a scatter of postholes.

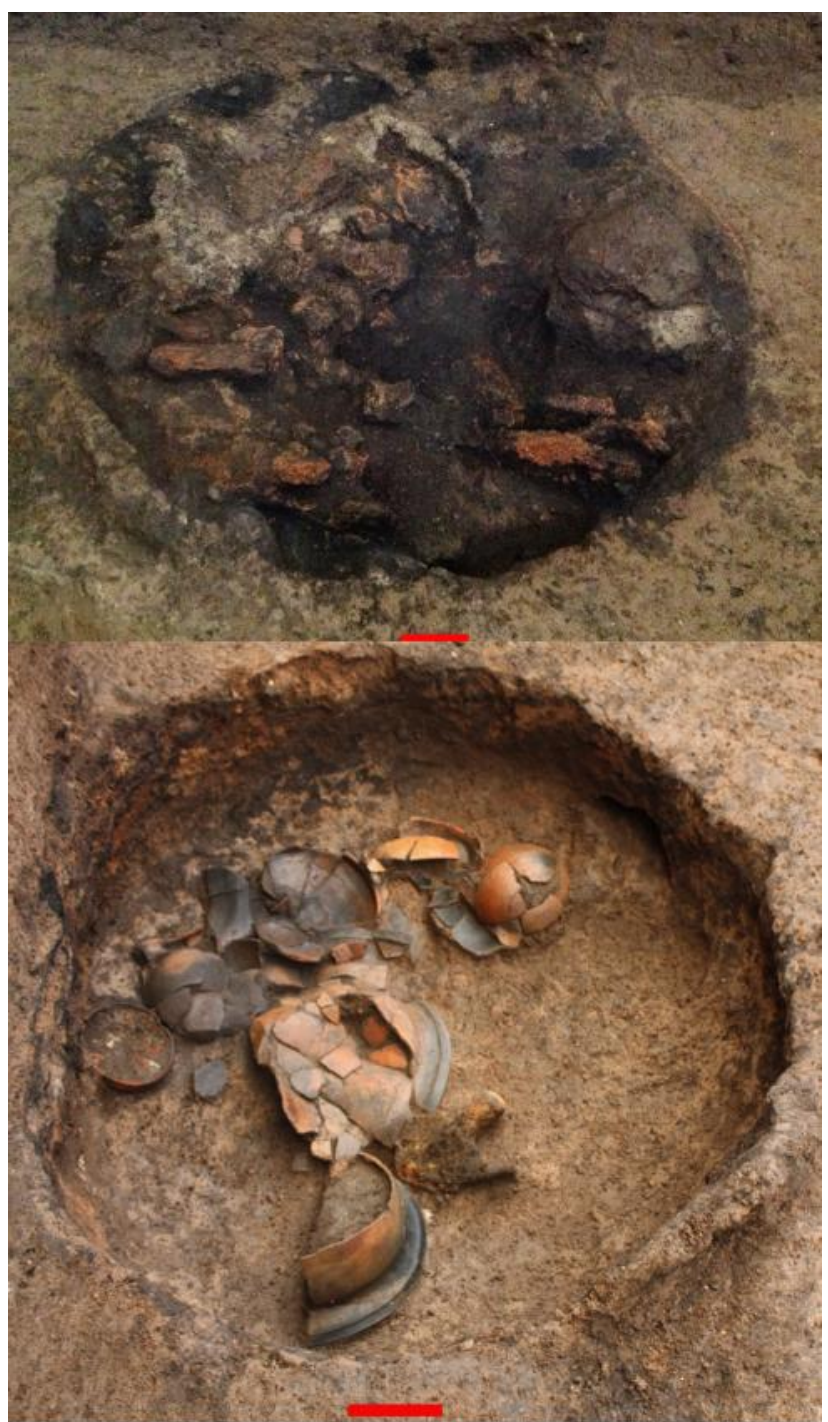

Figure 8: The kiln in layer 5. Above, prior to excavating the wall collapse and below, fully opened. Pottery vessels remained within, together with a socketed iron ploughshare one wing of which had been fractured in antiquity. Scale $10 \mathrm{~cm}$.

With the removal of the overburden of daub, charcoal and ash from the kiln rake out, we encountered a lens of large sherds being an accumulation of broken pots, or wasters, from firing. At this juncture, we also defined the circular edge of the kiln after removing a quantity of broken daub. To the west of the rake out, there was a lens of white rice, and beyond further, a hearth, ash, and charcoal. A second concentration of burnt clay and ash was found along the western edge of the excavated area. There are also a number of postholes.

Below it lay a circular enclosed kiln for firing vessels of variable form. At least eight were found in situ (Figures 8,32 ). The kiln was fashioned from clay liberally tempered with rice straw. A channel for the introduction or ouflow of air was found. The quantity of charcoal mixed with the daub and lying outside the circular kiln, which had a diameter of $1.20 \mathrm{~m}$, suggests that the heat was applied from wood or charcoal itself. A socketed iron implement with wings, one of which had been broken in antiquity, accompanied the pots. Why this should be so is hard to trace. The asymmetric profile of this artefact, and the presence of wings, suggested to the local rice farmers that it was a ploughshare rather than a spade. An almost identical artefact was found as a mortuary offering at Noen U-Loke during Iron Age 3 (Connelly 2007:435).

The structure of the kiln, quantity of charcoal, liberal presence of rice chaff and straw and presence of a possible chimney or tuyère to allow the ingress or escape of air from the interior, are all precisely mirrored in the kilns now used to convert wood into charcoal.

Burial 12, an adult, was just present in the southeastern corner of the square. It dates to the late Iron Age. In the northwestern part of the square, there is a large discrete area that had been subjected to heat. Two smaller similar contexts were found in the southern part of the excavation. A possible clay wall on a north to south axis was found near the southeast edge of the square.

The lowest context in layer 5 comprised the disturbed remains of a structure represented by a grey clay floor, part of a burnt wall and several postholes.

\section{Layer 4}

Layer four contrasts with its predecessor by a distinctly yellowish colour and an increase in the amount of occupation material lying on the surface. There is also a marked increase in the number of ash-filled hearths. The surface of layer 4-1 is dominated by the two building phases indicated by superimposed wall foundations on the same orientation. Essentially it was possible to recognize three or four chambers. The three on the western part of the square contain very poorly preserved fragments of clay flooring, and there are two hearth areas together with a possible internal buttress or furnishing also of clay. The middle and southern rooms were cut into by a later rectangular pit. The base of wall three, which lies on the eastern edge of the excavation, is still present. Concentrations of pottery and darker occupation lenses are found along the southern part of square

Layer 4-2 was dominated by two rectangular rooms in the western half of the excavated area. It is evident that the walls of these rooms were rebuilt over time. The northern room had within it on the southern wall, an internal buttress, which might have been an item of furniture, and two hearths. 


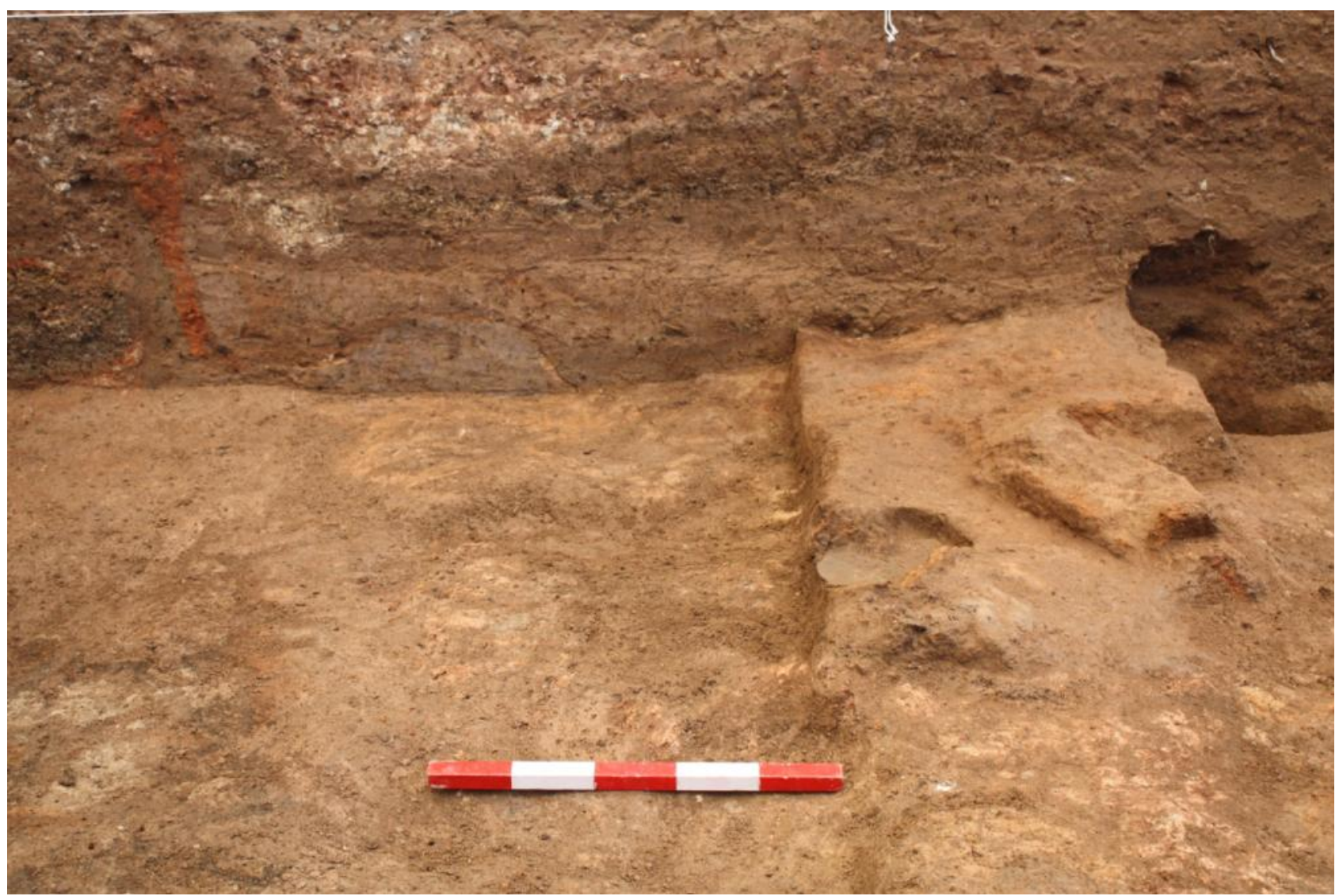

Figure 9: The surface of layer 4-7, showing mounds of laterite, clay lined furnaces and in section, much evidence for heat. Scale 50 $\mathrm{cm}$.

Layer 4-3 incorporates the clay base of a wall within which there is a grey clay floor. Postholes lie just outside the wall and were probably part of the structure. The wall proceeds in a westerly direction, and contains to the south a deposit of decayed laterite, an area of burning, concentrations and pottery and animal bones. The northwestern quadrant contains the lower part of a clay buttress belonging to a building that had already been removed. A hearth was found to the west of this buttress, and floors within it to the north.

Layer 4-4 contains the laterite foundation walls for probably two structures on an identical alignment as later buildings. The southern building incorporated what might well have been a cooking area. This comprises a series of hearths constrained within thick mounds of laterite. There are two complete pottery vessels, and the articulating limb bones of a bovid. To the north, there is a double set of parallel walls, albeit poorly preserved, and part of a clay floor. There is a small number of postholes, three pits, and one or two concentrations of Phimai Black potsherds.

Layer 4-5 incorporated in the southeastern quadrant, a laterite wall foundation at a depth of $2.69 \mathrm{mbd}$ lying on the same orientation and below the later structures in this part of the excavation. A row of three postholes lying alongside and to the west of the wall was probably part of the same structure. To the southwest lay a concentration of clay-lined hearths or areas of burnt clay. A singular feature of the southern edge of the square, was a set of two thick mounds of decayed laterite within which lay a further hearth and concentration of ash. A grey clay wall foundation again on the same orientation as its successors was identified in the southwestern quadrant. Further north, there were more hearths and a clay wall associated with further superimposed floors. Two sets of lid-to-lid Phimai Black pots were found on the same east to west alignment of this wall.

Layer 4-6 contains the foundations for a laterite wall at a depth of 2.74-2.78 mbd. It lies under and on the same orientation as the walls above it in layers 2 and 3. The northern edge of the square also contains the badly preserved remains of a clay floor. In the middle of the square, there is a dense concentration of Phimai Black potsherds, lying west of the wall foundation, as well as a hearth. A marked feature of the southern part of this area, is a concentration of five clay-lined hearths, filled with ash and on occasion bone and potsherds. The southwestern corner is an area subjected to considerable burning. There are two raised laterite accumulations surrounding a rich charcoal deposit.

The southwest quadrant of layer 4-7 incorporated, as did the layer above, evidence for the construction of a series of clay-lined furnaces. The presence of iron slag and deposits of laterite suggest that these were employed for smithing, or alternatively, possibly for smelting. The analysis of the slags and laterite are not yet initiated (Figure 9). 


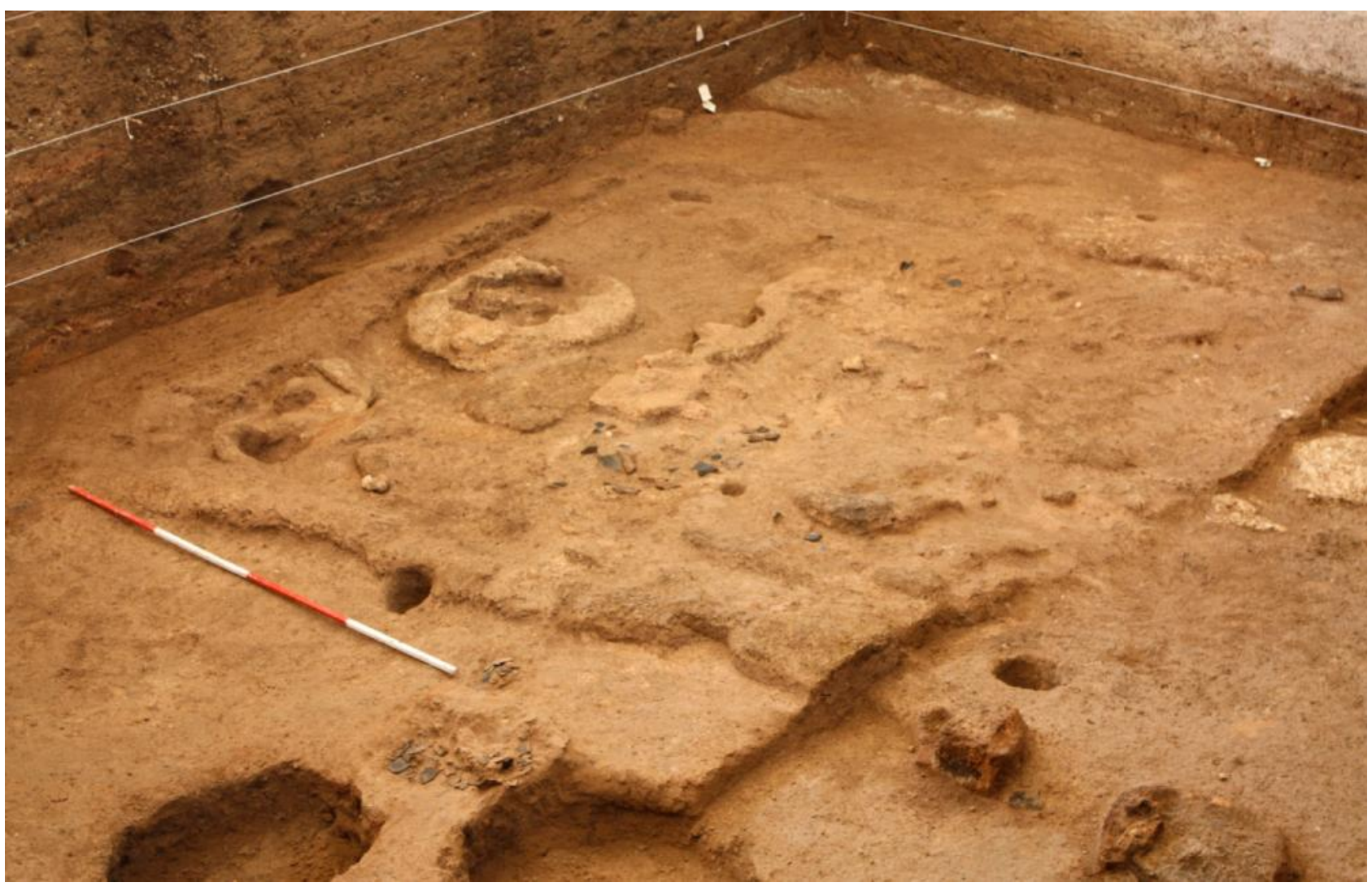

Figure 10: The surface of layer 4:8 looking to the southwest. The configuration of a new structure is clearly seen.

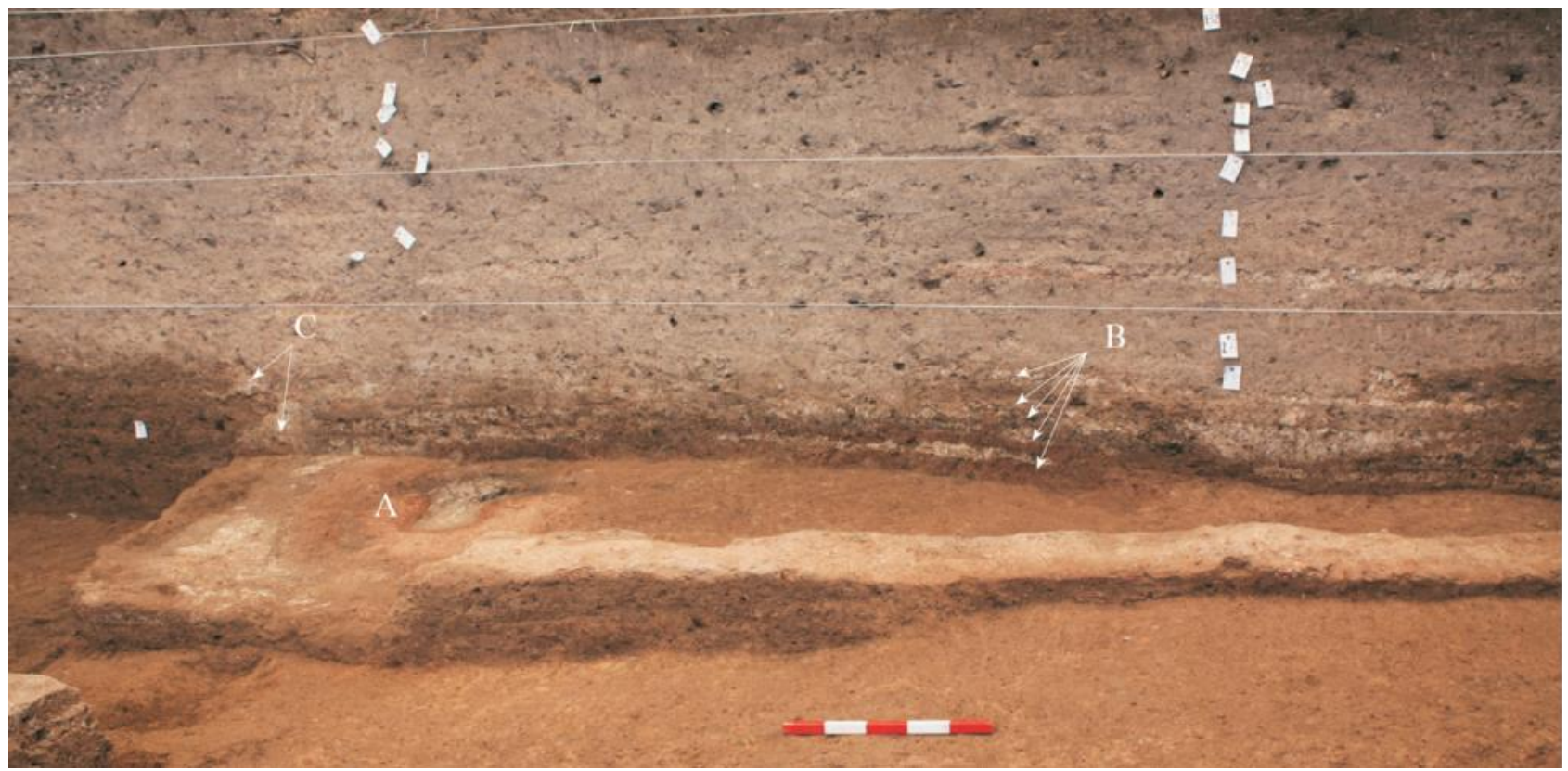

Figure 11: Layer 3 southeastern room, viewed from west. A. hearth, B. superimposed floors, C. superimposed walls. Scale $50 \mathrm{~cm}$.

A burnt red clay floor lies to the northeast of this concentration. In the northwestern quadrant, a mutilated clay floor lies adjacent to a clay wall foundation, suggesting that there was a residential complex in this part of the site. A laterite wall foundation runs a few degrees west of due north in the central part of the square, and there are also several postholes that were dug from this depth.
The surface of layer 4-8 contained, in the southern part of the square, the first indications of a house structure, seen in the configuration of wall foundations (Figure 10). These were made of clay and laterite. A badly disturbed laterite floor lay within the rectangle formed by the southeastern corner of the room of this house, over which lay a circular hearth of compacted ash and flecks of char- 
coal. There were also concentrations of potsherds within and just beyond this room, and the base of a pottery vessel. The red clay floor to the east of this chamber was first uncovered in layer 4-6. A wall running parallel with the clay wall in the centre of the square is found in the southeast corner.

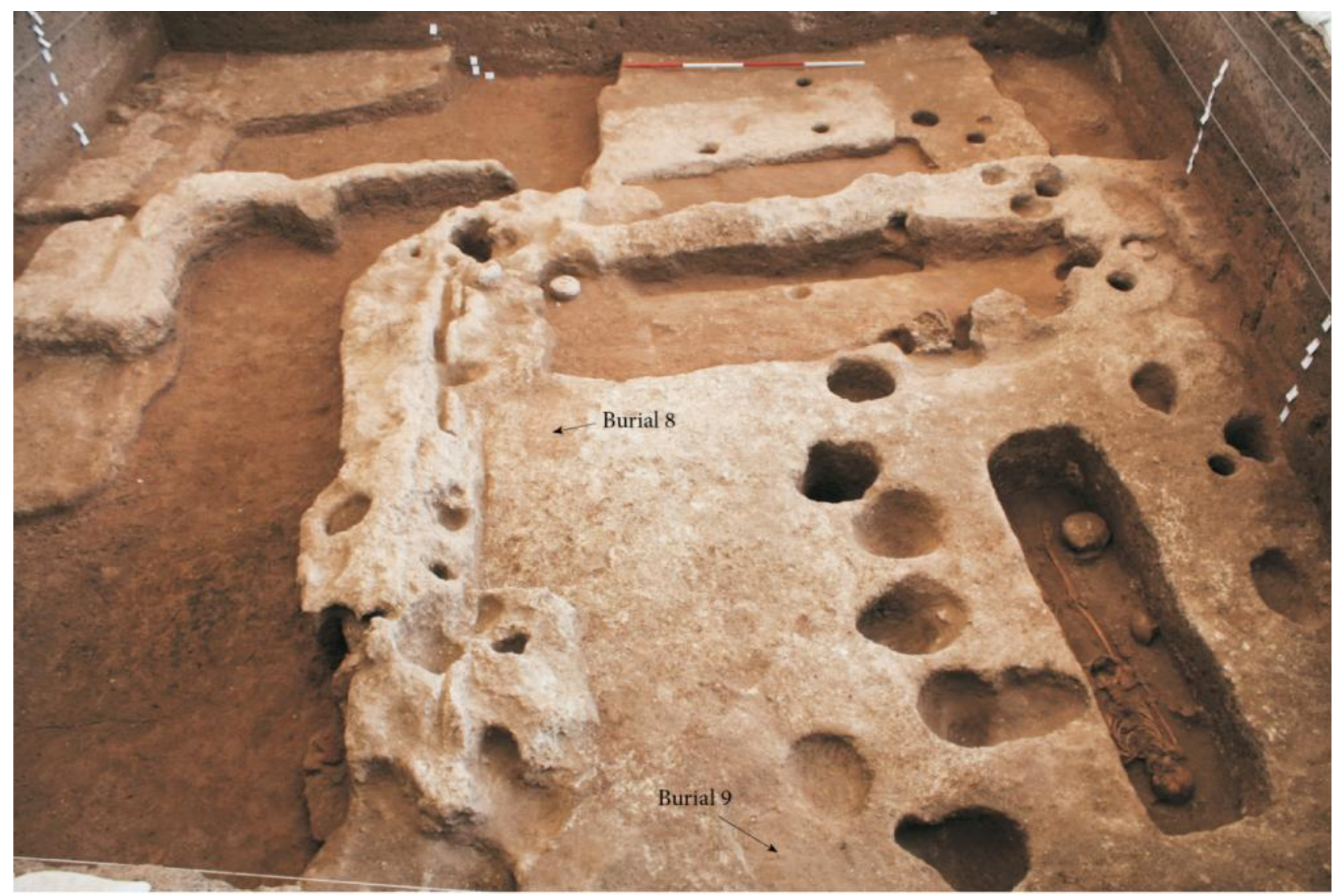

Figure 12: Lower layer 2, looking south. The grave cuts for burials 8 and 9 can be seen on the surface of the floor within the possible mortuary chamber. Burial 7 has been exposed. A rectangular clay floor can be seen on the surface of 2:8 in the distance, cut by a rectangular pit. A lane between two buildings runs north-south on the left of the photograph before turning a right angle. Probably $6^{\text {th }}$ century $A D$.

Layer 3

Layer 3 was a thin occupation deposit under layer 2 structures. On removing the walls of the layer 2 burial chamber and the associated buildings, a further set of walls on the same orientation were encountered. These enclosed in the southwestern quadrant, a solid clay floor containing a rectangular cutting of mottled fill. The rectangle was surrounded on the western and southern sides with rows of postholes. This looked very like a further grave cut, but when opened, it was found to contain no such remains. The wall to the north of this floor had been cut into with the creation of the grave for burial 7 . There is a further structure on the eastern edge of the excavation. It comprises a wall foundation of white clay with a lining of grey clay. Within, there is a series of superimposed grey or red clay floors (Figure 11), and in the southeastern corner, two hearths. A third hearth filled with grey ash was found towards the north of the room. It is evident that this room was occupied over such a period of time that reflooring was periodically necessary.
Layer 2

The upper contexts in layer 2 incorporated concentrations of Phimai Black potsherds, indicating continued late Iron Age occupation. Burial 1, an infant, was found in the southern edge of the excavation. It was associated with a small number of glass beads. Historic period pits were cut down into upper layer 2, as well as some postholes.

Layer 2-4 revealed the surface of wall foundations in the southwestern quadrant. Lying adjacent to the northsouth wall, was burial 3. The orientation of this person was with the head to the south. Just to the north, burial 2 was encountered in the base of a historic period pit. It is assumed that this pit dug through and disturbed an Iron Age burial. In the northeast quadrant, there were three sets of lip to lip Phimai Black vessels. The two in close conjunction were found south of a deep cut within which we encountered burial 6 . A white clay floor dominated the eastern part of the area opened.

Layer 2-5 included further clay walls and the intervening town lane between two structures. The bases of several pits impinged on these walls. One of these had proba- 


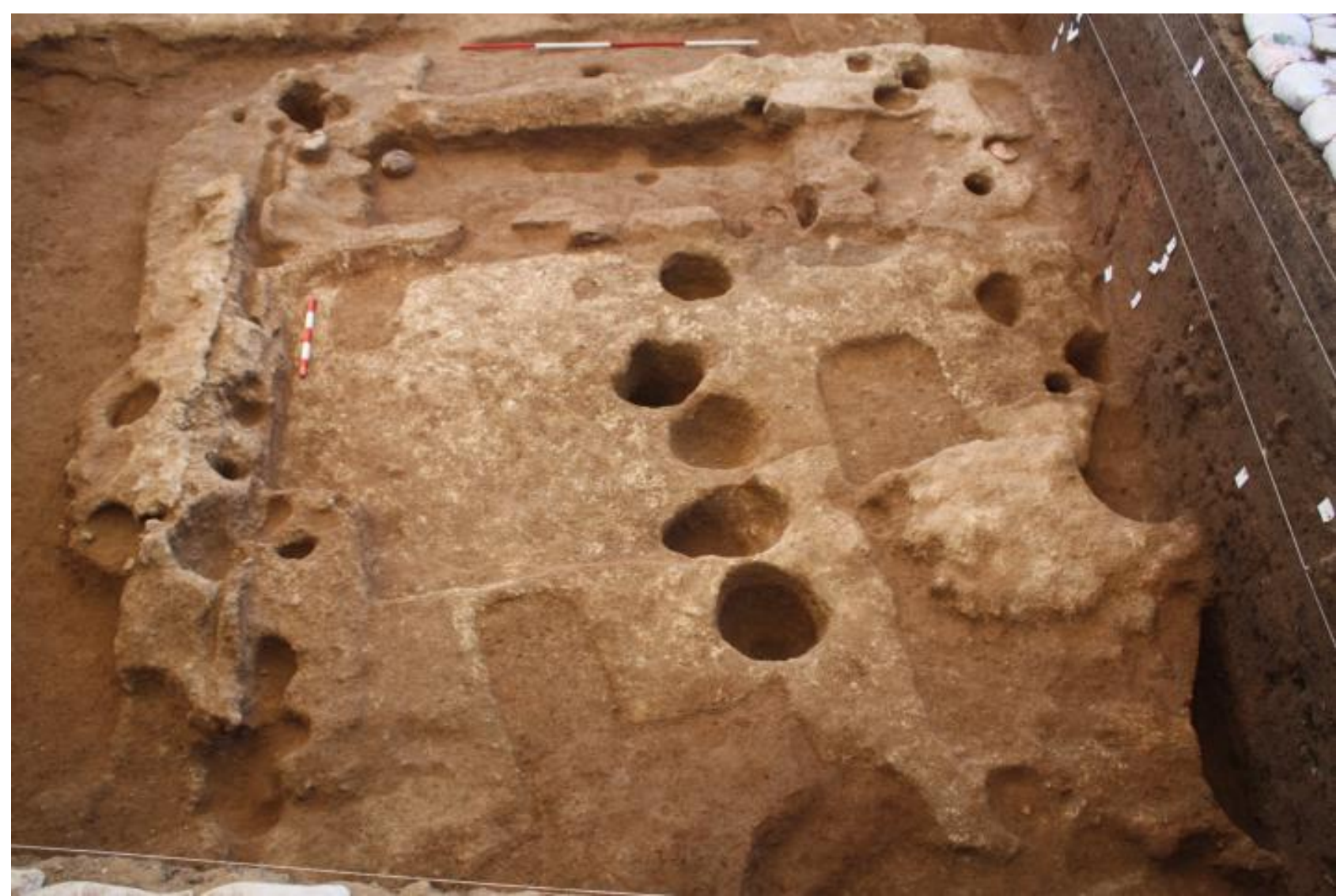

Figure 13: The mortuary chamber, looking south. Note the surviving part of a floor sealing the cut for burial 7, and the clear grave cuts for burials 8 and 9. The central row of postholes were probably to support the roof. Probably $6^{\text {th }}$ century AD.

bly disturbed an earlier adult burial, the bones from which were scattered within the pit (burial 2). This pit also contained the cranium and upper bones of an infant (burial 4). The walkway in the southwestern quadrant contained the limb bones of a further infant (burial 5). In the northeastern quadrant, there are two sets of lip to lip Phimai Black pots lay at a higher level and to the south of burial 6 . This child was interred on a north to south axis, with the head to the north. It was associated with two Phimai Black pottery vessels, an iron earring and an iron sickle by the right hand.

The surface of layer 2-6 incorporated the top of the wall foundations and a buttress for the two structures the floors of which were to be uncovered at a lower level. At this juncture, the gaps between the northwestern and southeastern walls were designated walkways or town lanes. The bases of three large pits dug down during the historic period are seen in the northwestern quadrant.

Lower layer 2 incorporated a series of walls divided by lanes. The interior of the room in the northwest quadrant contained a plastered clay floor through which a rectangular pit had been cut. Three burials lay within this chamber, all on the same orientation as the north to south walls (Figures 12-13). One is an adult, and there is also one child and an infant. The adult burial lies within two parallel rows of large postholes. A hearth is found in the southern half of this room. Lip to lip Phimai Black pottery vessels were placed in three of the corners of this cham- ber, with a fourth set also in the southeast corner. The northeastern corner was disturbed in antiquity, and no such vessels survived there. There are also some broken pots in the southern part of the chamber. This room is separated from the building to the southeast by a lane that, unlike the rooms themselves, contained occupation debris dominated by broken Iron Age potsherds.

No further burials were found in these rooms, but a set of hearths was present in the southeastern corner room. It is possible that this complex represents a domestic dwelling while the chamber to the northwest was employed for interring the dead. An alternative interpretation could be that both buildings were occupied, and the burials were cut down through the clay floor after they were abandoned. This seems unlikely given the identical orientation and regular placement of the graves relative to the room that contains them, and the possible ritual nature of the precisely located pottery vessels in at least three corners of the room. Moreover, a clay floor or possibly a collapsed wall was found partially to cover part of the grave of burial 7 (Figure 13).

In this respect, it is particularly noted the expenditure of energy devoted to wall construction during this period (Figure 14). The foundation is at least $50 \mathrm{~cm}$ wide, and comprises white solid clay, of the sort that would have been available during the excavation of the moats to form the retaining banks that ring the site. The interior edge of the wall contains a line of postholes for timbers that 
would have supported the roof. A narrow channel running between the posts and the wall may well have been the foundation for the interior lining of the chamber. The floor abutted the wall and one of the sets of lip to lip Phimai Black pots was lodged hard against the latter, sitting on the surface of the clay floor through which the grave of burial 8, located in this vicinity, had been cut.

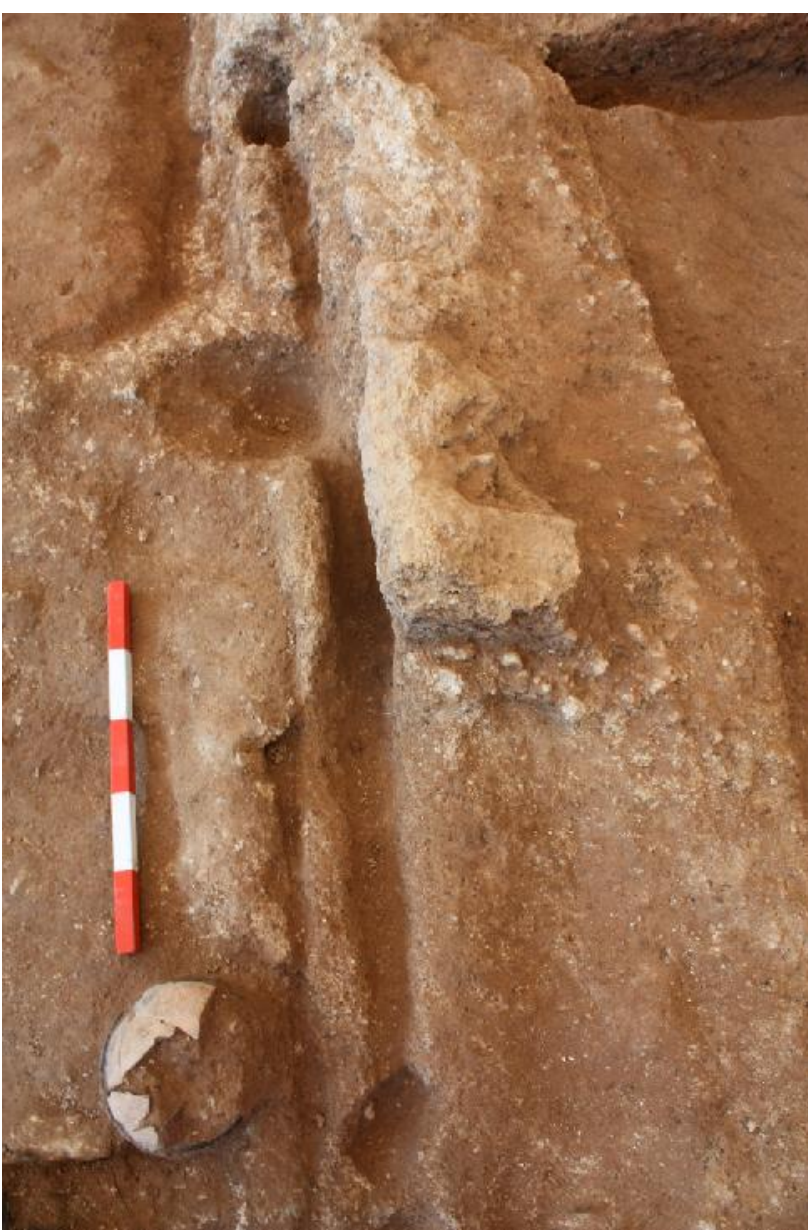

Figure 14: The eastern wall of the mortuary chamber. Note its marked breadth, structural post foundations, and the lip to lip set of pottery vessels adjacent to the wall. Scale $50 \mathrm{~cm}$. Probably $6^{\text {th }}$ century $A D$.

\section{Layer 1}

Layer 1 incorporates a series of pits, containing broken pottery vessels and animal bones: large deer, cattle and water buffalo. There are also several concentrations of burnt clay. These might well have come from wattle and daub structures. In the southeast corner of the square, there as an extensive shell midden. There are also several postholes. It is evident that Non Ban Jak was occupied during the early historic period for the broken pottery vessels are similar to those recovered from Dvaravati sites in Central Thailand (Figure 15).

\section{THE EASTERN MOUND BURIALS}

The excavation of Non Ban Jak encountered a residential quarter of the site. However, several burials were identified, three of which were found within a chamber in one
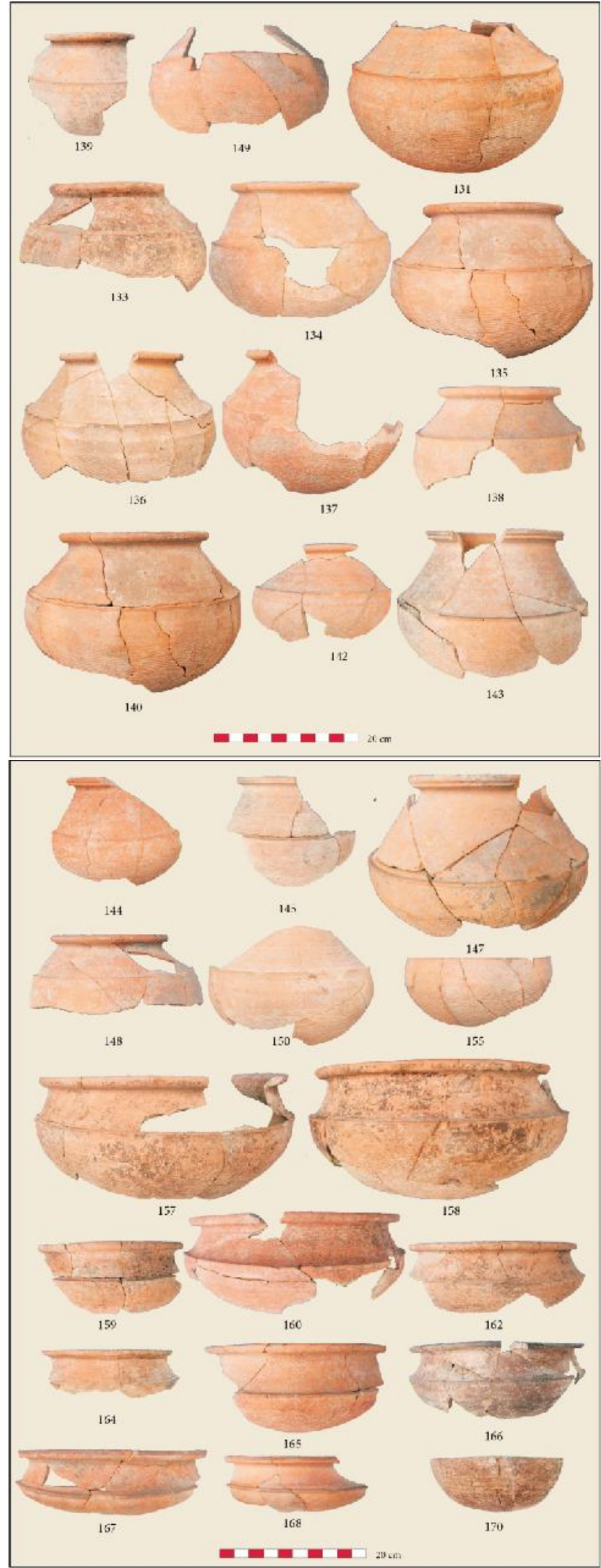

Figure $15 a \& b$ : The historic period ceramic vessels

of the buildings in circumstances which suggest that this was a ritual room designated for burial. This stems from the fact that the infant burial was located in one corner of the room, and burial 7, an adult, was partially covered by 


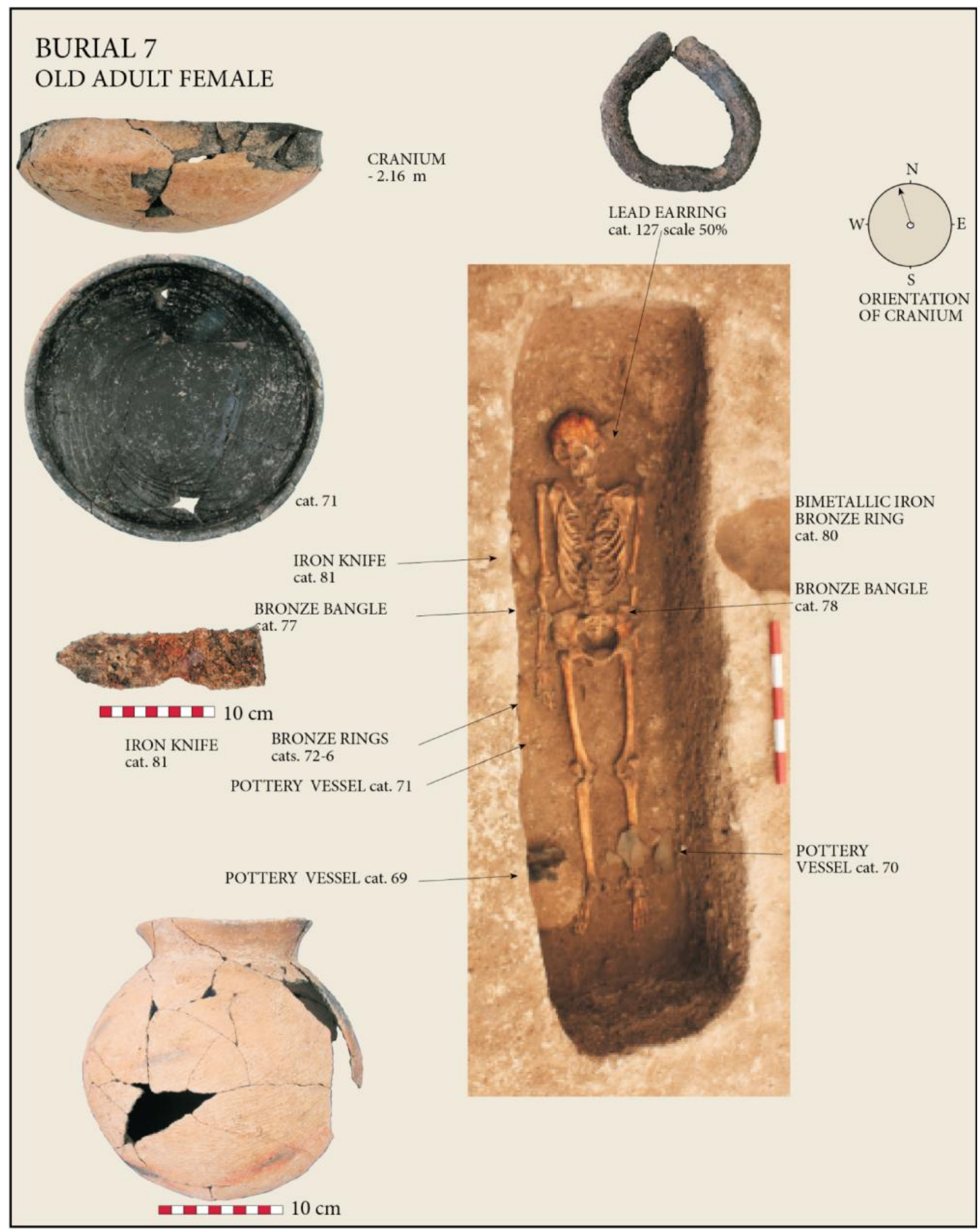

Figure 16: Burial 7, a woman interred in a layer 2 room.

a floor or possibly collapsed wall. It is also the case that the room in question, unlike rooms in the southeastern quarter, which had many superimposed clay floors, had only two or three thick white clay floors. Two of the lower residences also contained rooms in which an infant grave had been cut through a floor. The best preserved 


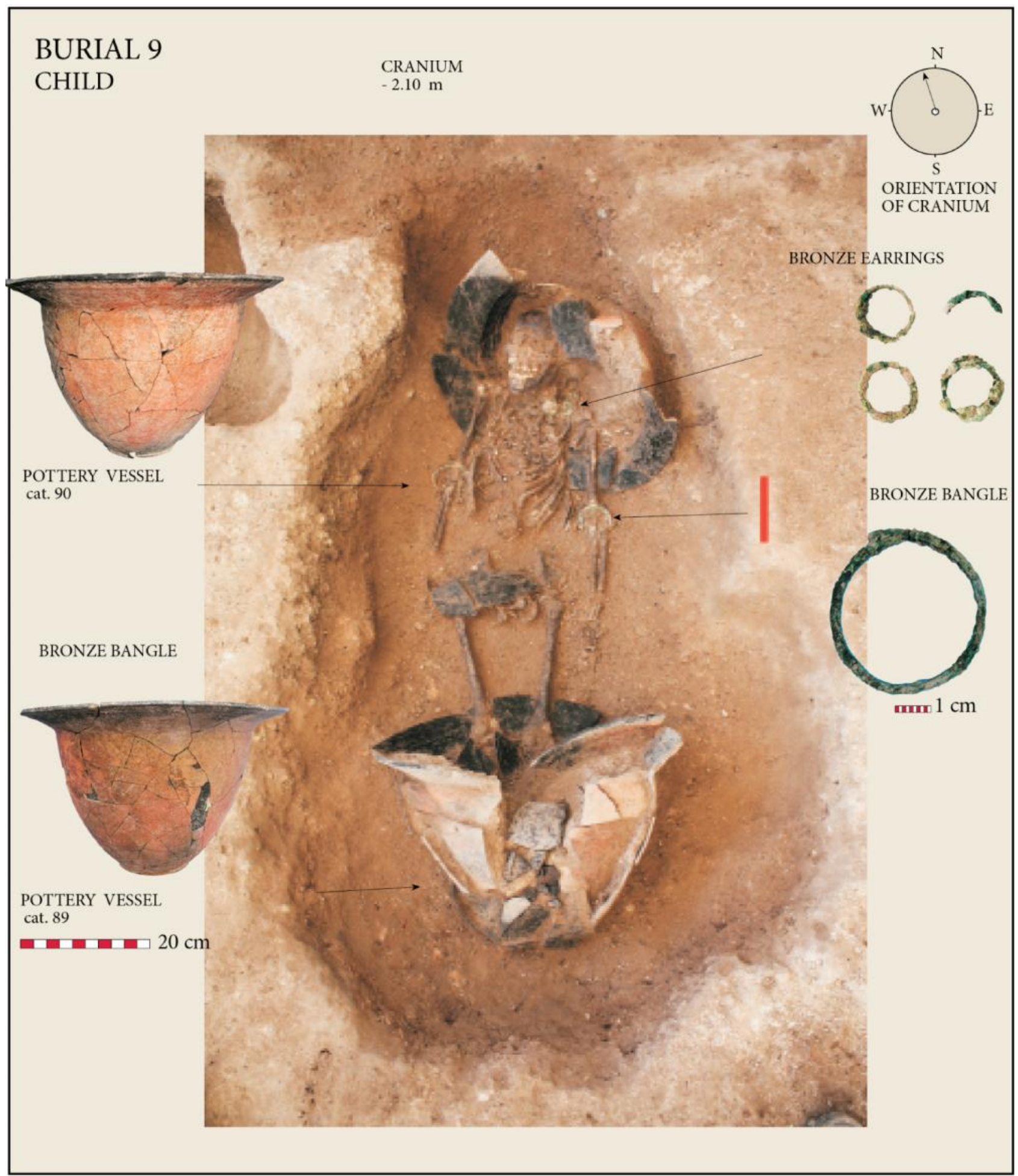

Figure 17: Burial 9.

was centrally placed within a room, suggesting that it was associated with the building rather than a later burial fortuitously interred into an unrelated structure.

Burial 1 comprises the bones of an infant in layer 2-2, Burial 5, a second infant, was found within a lane in layer 2-4. Burial 4, a further infant, was found at the base of an historic period pit in layer 2-4. It is likely that the pit damaged but did not completely disturb this infant burial when it was dug. Burial 8 is the complete grave of an infant, found in the southeastern corner of the mortuary chamber which also contained the remains of burials 7 and 9. No mortuary offerings were found in this grave.

Burial 7 was found at a depth of $2.16 \mathrm{~m}$ below datum with the head orientated slightly to the northwest (Figure 16). The grave lay within a mortuary chamber, positioned between two rows of large postholes. The body was found 
on the back, about $40 \mathrm{~cm}$ below the floor through which the grave was cut. Personal ornaments comprised five bronze rings on the right hand, a bronze bangle on each wrist, a lead earring and a bimetallic ring on the chest. Three pottery vessels were present, a Phimai Black bowl by the right hand, a large cord-marked vessel by the right ankle and a further fragmentary vessel by the left ankle. An iron knife blade had been placed by the right elbow.
Burial 9, a child, was found within the same mortuary chamber and on the same orientation, at a depth of $2.10 \mathrm{~m}$ below datum. The head was found within a pottery vessel, and the feet in another. This child wore a bronze bangle on each wrist and bronze earrings (Figure 17). Burial 6, another child, was found interred with a large ceramic vessel, an iron earring and iron sickle.

$\mathrm{AA} 2$

BB2

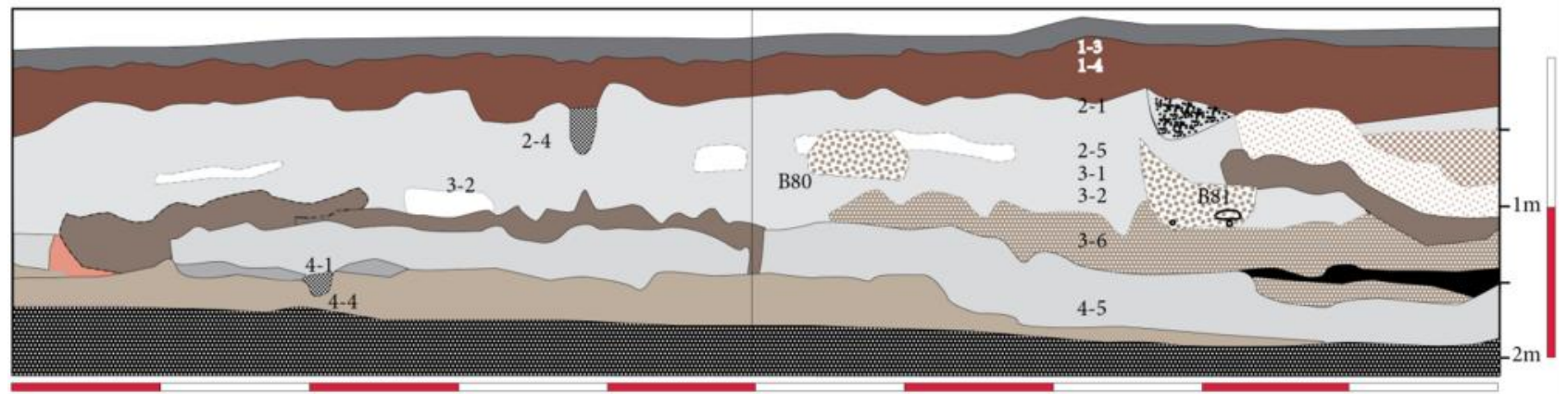

most hole $\square$ dark clayey fill with laterite nodules and potsherds $\square$ clean dark silt $\square$ mottled light clayey silt

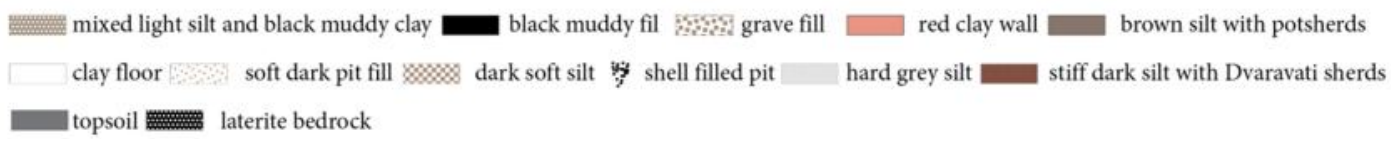

Figure 18: The southern section at squares $A A 2$ and BB2 in the western mound.

\section{THE WESTERN MOUND}

The stratigraphy of the excavation that straddled the low ground and the rise up to the western mound varied remarkably. There were no structures and virtually no features in the former part of the square, until the laterite natural substrate was encountered at a depth of about $2 \mathrm{~m}$ below datum. At this point, human burials were found either lying on the laterite, or slightly excavated into it. However, with the rising ground to the west, a series of walls and floors were encountered in a complex sequence encompassed within four layers (Figure 18). The relationship between human graves and the structures has underwritten the recognition of four mortuary phases, the earliest of which corresponds to those found resting on the natural laterite. The occupation of this part of the site began in the $4^{\text {th }}$ century AD and lasted for about $300-400$ years. This period, and the associated material culture, corresponds to the fourth and final phase of the Iron Age at Noen U-Loke (Higham et al. 2007) and extending into the period of the Dvaravati state.

\section{Layers 3-4}

The upper contexts of layer 3 contained the remains of occupation, including clay floors along with complete ceramic vessels and scatters of ash and concentrations of potsherds. Infant and adult burials were cut down to this layer (Figure 19).

Proceeding into layer 3 , it was found that domestic activity was concentrated in the western part of the excavated area, with clay floors under concentrations of pottery, ash and stones. Burial 84, an adult, was found with no cranium. Two infant burials were found in the eastern area, burial 30 being an extended, supine inhumation. With layer 3-3, the eastern part of the excavated area included three infant jar burials, and some complete pots. Proceeding to the west, a large ceramic kiln was opened. Mortuary phase (MP) 2 burials were now encountered in the upper contexts of layer 4. Burial 108 was found covered by a clay floor. A row of postholes on the same orientation as the walls ran north south across the square, and in the northwestern corner, burial 105 was found oriented uniquely from west to east.

This basal layer accumulated directly over the natural substrate. MP1 burials concentrate in the eastern part of the excavated area. There seem to be two groups separated by a four metre gap. The many infant jar burials during this period suggest a remarkable degree of infant mortality.

\section{Layer 2}

The transition from layer 1 to 2 is barely noticeable. Again all the activity is confined to the western part of the excavated area with a system of walls and floors, through which burials were inserted. There is also evidence for occupation in the form of pits and concentrations of pottery sherds. Burial 72 was cut through a floor, at the corner of a clay wall. Burials 76 and 77 lie within the clear grave cut through the floor in AA2 (Figure 23). Further walls and floors appear in BB1 and 2.

With layer 2-3, burial 49 was cut into the edge of a clay wall. Further west, a series of burnt floors suggest that a fire had taken place prior to the interment of burials 76-8 through a floor. Slightly deeper in layer 2-4, concen- 


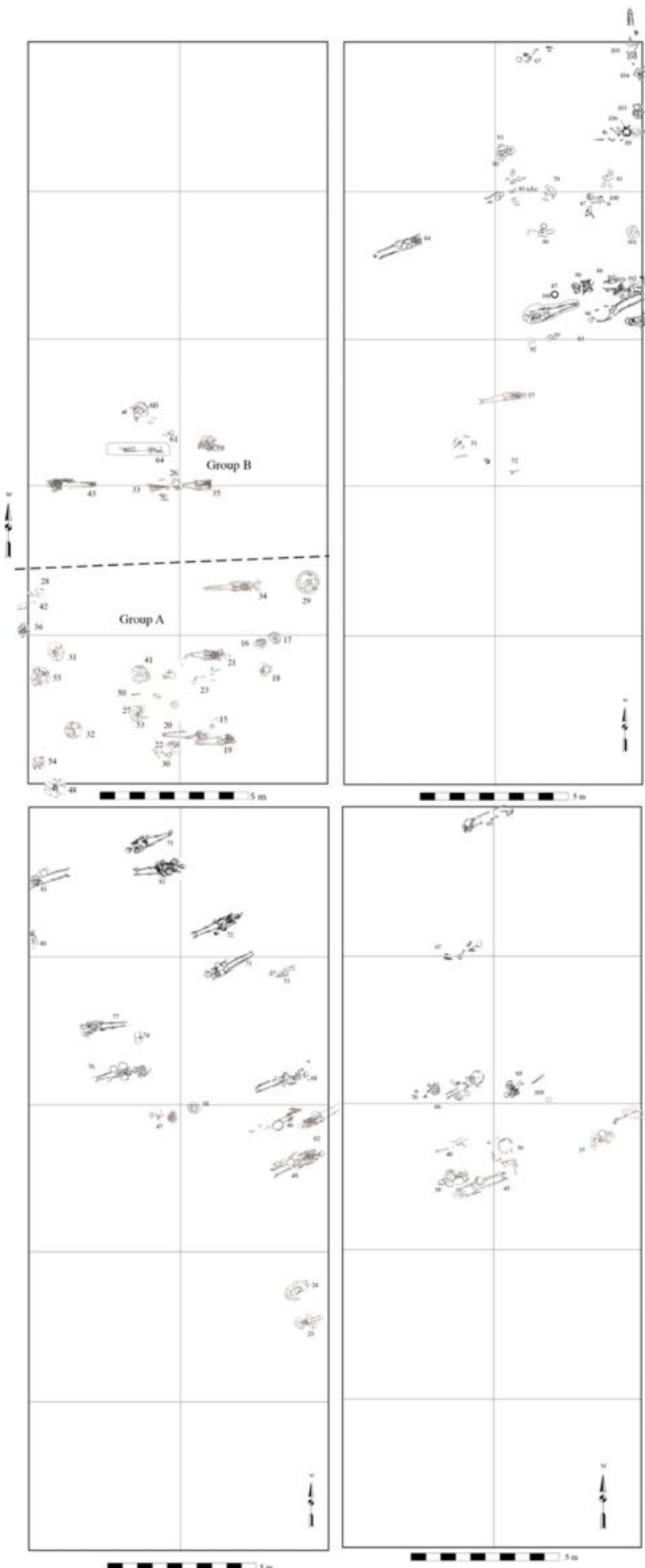

Figures 19-22: Western mound burial locations in Mortuary Phase 1 (top left), 2 (top right), 3 (bottom left) and 4 (bottom right)

trations of ash and potsherds, postholes and pits suggest that at this juncture, the western part of the site had do mestic occupation. In AA1, a clay wall was identified on a precise north to south orientation.

Layer 2-5 incorporated a clay floor associated with the north to south wall in AA1, together with infant burial 83, which was interred abutting the eastern side of the wall. Many ash spreads further reflect burning. In BB2, burial 82 was located. This individual wore two bronze belts matched at Noen U-Loke during Iron Age 3.

Layer 1

According to the villagers, the top of the site in this area has been levelled with a bulldozer. Hence the late Iron Age burials are found very close to the present surface. The western part of the excavated area, barely $15 \mathrm{~cm}$ below the surface, had a number of concentrations of potsherds, shellfish, animal bone and some complete vessels, indicating that this part of the site had been occupied during the late Iron Age. MP 4 burials were encountered in the uppermost context of this layer. In Y2, there is an concentration of burnt clay. Scatters of concentrated potsherds and shellfish as well as some postholes suggest that occupation also took place in this part of the site.

With layer 1-3, there is evidence in the western part of the excavated area for structures represented by clay walls and floors. MP4 burials continued at the level, together with concentrations of potsherds and shells. An area of burnt clay is found in Y2.

\section{Summary}

There was evidently a concentration of activity in the western part of the excavated area but nothing to the east. Structural remains comprise wall foundations and clay floors. The former have postholes embedded in them, presumably for the walls, while walls also terminated with a large block of stone. Burial 71 was cut through a floor within a building, but the configuration of the walls to the west suggest the presence of a lane within the settlement. Burial 46 was also cut into a clay structure. There are concentrations of potsherds, that in AA1 being within the room containing burial 71. A wall in AA2 suggests that structures continue in a southerly direction to the interior of the settlement.

\section{THE WESTERN MOUND: THE MORTUARY SEQUENCE}

\section{Mortuary phase 1}

The burials of MP1 were disposed in two groups, one centrally in the excavated area and the other at the eastern end (Figure 19, 24). Thirty-two graves were identified of which 16 involve infants most of whom were interred in lidded ceramic vessels. Of the adults, there were three females, four males and 10 of undetermined sex. If a reflection of the real situation, the number of infant burials is one of the highest recorded in prehistoric Southeast Asia. The adults were buried supine, on a north to south axis, with a preference for the head directed to the north. One adult was interred in a flexed position and was probably a secondary burial. Mortuary offerings were sparse. Indeed compared with the wealth of the contemporary graves at Noen U-Loke, this group of individuals, who might well represent the initial settlers of Non Ban Jak, were impoverished. One or two pottery vessels were 


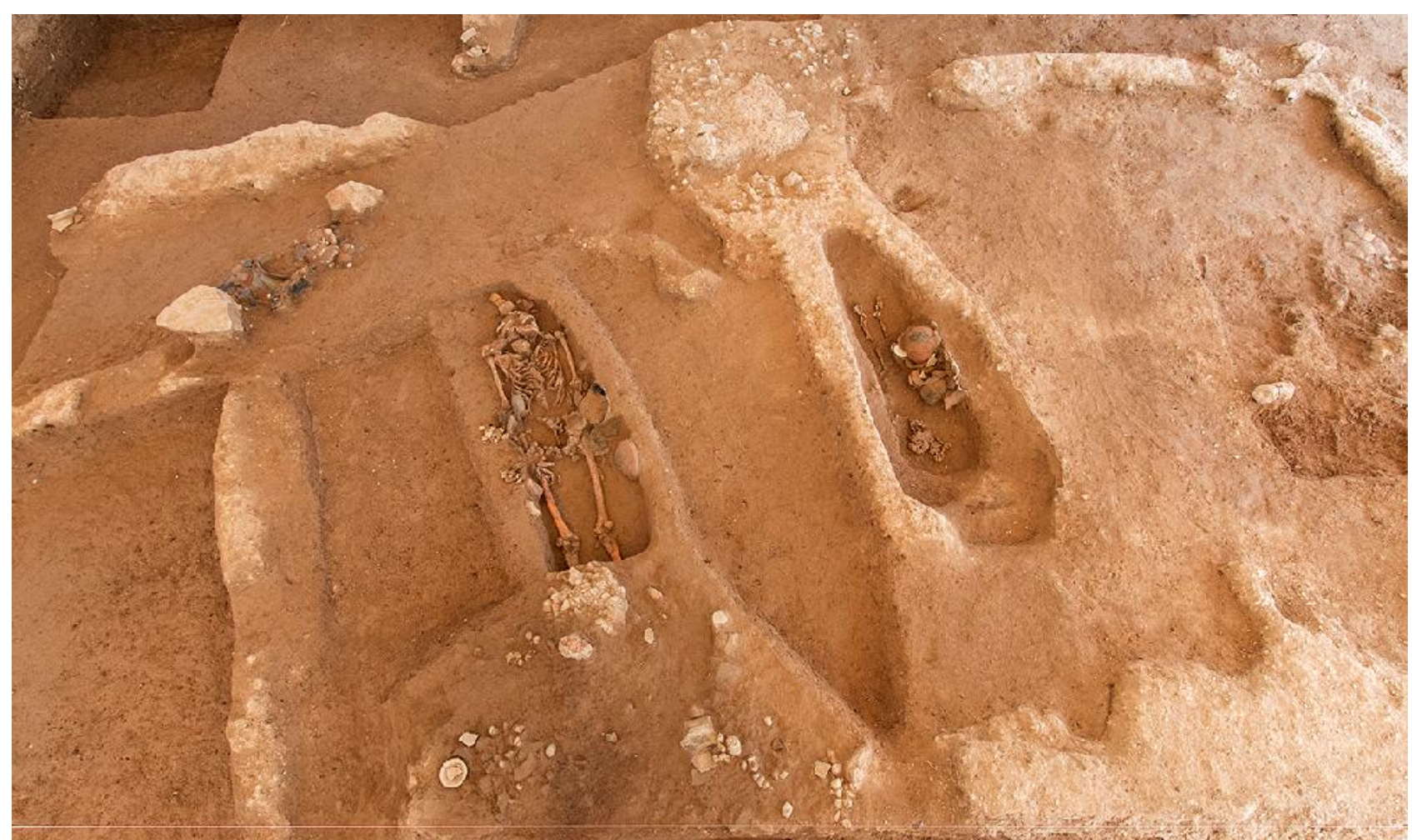

Figure 23: Burials 76 and 77 of Mortuary Phase 3 were cut through a floor, on the same orientation as the walls of a room.

found with most of the adult dead, with just two forms represented: a cord-marked globular vessel and an open bowl. There were no iron mortuary goods. One man wore 16 bronze bangles, and one or two other bangles, finger and toe-rings of bronze were also recovered. Other ornaments were equally sparse; one man wore an agate and a shell pendant, and another probable male, a silver coil on each ear. The flexed burial was associated with a collection of red glass beads. Animal bone offerings were rare, and confined to pig bones.

All but two of the infants were interred in lidded ceramic vessels, most of the forms being paralleled at Noen U-Loke and Ban Non Wat during Iron Age 4. The two other infants were interred like the adults, supine, and with the head orientated to the north. Mortuary offerings were dominated by ornaments, although never in the abundance seen at contemporary Noen U-Loke. The infant in burial 30 wore seven bronze bangles, and other bronzes were found in the form of a ring, an earring and anklets. The infant in jar burial 32 wore three bronze belts. Glass beads were found with eight of the infants. There is a long tradition in the upper Mun Valley sites from the Neolithic onwards for the association of bivalve shells with the dead, and this was continued with four of the MP1 infants. Burial 59 also wore two Anadara shells pierced for suspension. This is a marine species, indicating long distance exchange. The only MP1 iron offerings come from burial 30 in the form of two bangles.

Table 3: The finds associated with intact adult burials of mortuary phase 1

\begin{tabular}{lccccccc}
\hline Burial & 19 & 20 & 21 & 34 & 35 & 43 & 64 \\
\hline Sex & F & M & M & F & M & - & $? \mathrm{M}$ \\
Age & A & A & A & MA & OA & A & MA \\
Orientation of head & N & N & N & N & N & S & N \\
Pots & 0 & 1 & 1 & 2 & 2 & 1 & 1 \\
Bronze bangle & 0 & 2 & 16 & 0 & 2 & 0 & 2 \\
Bronze finger ring & 1 & 0 & 0 & 0 & 0 & 0 & 0 \\
& & & & & & & \\
Bronze toe ring & 0 & 1 & 0 & 0 & 0 & 0 & 0 \\
Bronze anklet & 0 & 1 & 0 & 0 & 0 & 0 & 0 \\
Silver ear spiral & 0 & 0 & 0 & 0 & 0 & 0 & 2 \\
Stone adze & 1 & 0 & 0 & 0 & 0 & 0 & 0 \\
Glass beads & 0 & $\mathrm{p}$ & 0 & 0 & 0 & 0 & $\mathrm{p}$ \\
Agate pendant & 0 & 1 & 0 & 0 & 0 & 0 & 0 \\
Shell pendant & 0 & 1 & 0 & 0 & 0 & 0 & 0 \\
Spindle whorl & 0 & 0 & 0 & 0 & 0 & 0 & 1 \\
Pig bones & 0 & 0 & 2 & 0 & 0 & 0 & 0 \\
\hline & & & & & & & \\
\hline
\end{tabular}


Table 4: The finds associated with mortuary phase 1 infants

\begin{tabular}{lcccccccccccccccc}
\hline Burial & 16 & 17 & 18 & 26 & 27 & 29 & 30 & 31 & 32 & 41 & 48 & 54 & 55 & 56 & 59 & 60 \\
\hline Pottery vessel & 1 & 1 & 1 & 1 & 1 & 3 & 3 & 2 & 0 & 2 & 2 & 1 & 1 & 2 & 3 & 1 \\
Bivalve shell & 1 & 0 & 0 & 0 & 0 & 0 & 1 & 3 & 1 & 0 & 0 & 0 & 0 & 0 & 0 & 0 \\
Bronze bangle & 3 & 0 & 3 & 0 & 0 & 0 & 7 & 0 & 6 & 1 & 0 & 0 & 0 & 4 & 1 & 1 \\
Bronze anklet & 0 & 2 & 0 & 0 & 0 & 0 & 0 & 0 & 0 & 0 & 0 & 0 & 0 & 0 & 2 & 1 \\
Bronze ring & 0 & 1 & 0 & 0 & 0 & 0 & 0 & 0 & 0 & 0 & 0 & 0 & 0 & 0 & 0 & 0 \\
Bronze necklace & 0 & 0 & 0 & 0 & 0 & 0 & 0 & 0 & 3 & 0 & 0 & 0 & 0 & 0 & 0 & 0 \\
Bronze earring & 0 & 0 & 0 & 0 & 0 & 0 & 1 & 0 & 0 & 0 & 0 & 0 & 0 & 0 & 0 & 0 \\
Bimetallic ring & 0 & 0 & 0 & 0 & 1 & 0 & 0 & 0 & 0 & 0 & 0 & 0 & 0 & 0 & 0 & 0 \\
Iron bangle & 0 & 0 & 0 & 0 & 0 & 0 & 2 & 0 & 0 & 0 & 0 & 0 & 0 & 0 & 0 & 0 \\
marine shell pendant & 0 & 0 & 0 & 0 & 0 & 0 & 0 & 0 & 0 & 0 & 0 & 0 & 0 & 0 & 2 & 0 \\
Glass beads & $\mathrm{p}$ & $\mathrm{p}$ & $\mathrm{p}$ & 0 & 0 & $\mathrm{p}$ & 0 & 0 & $\mathrm{p}$ & $\mathrm{p}$ & 0 & 0 & 0 & $\mathrm{p}$ & 0 & $\mathrm{p}$ \\
p: present & & & & & & & & & & & & & &
\end{tabular}

\section{Mortuary phase 2}

Burials of MP2 concentrated at the western part of the excavated area (Figures 20, 25). There were five male, three female and four other adult graves, together with 21 infants. The proportion of infants, $64 \%$ of the sample, exceeded even that of the preceding phase. The ascription of burials to MP2 was based on their being sealed by later floors, and being at a higher level and different orientation to MP1 graves. Since there are no superpositions, however, the precedence of MP1 remains under review. The orientation was now with the head either northwest or southeast, with one male being interred with the head to the east. Mortuary offerings with the adults continued to involve globular cord-marked vessels and open bowls. There were also a few bronze bangles and rings. The first iron sickle and iron knife were identified, as well as a bimetallic iron and bronze ring of a size frequently found at Noen U-Loke. Four of the five intact adult burials contained at least one agate bead, and there were also bivalve shell offerings, beads and spindle whorls (Table 5).

Fourteen of the infants were found in mortuary jars, which were often lidded. The slightly older infants were buried like adults, supine and on the same orientation. Infants were accompanied by a more varied set of grave goods then the adults, and some could be described as being moderately wealthy. Thus burial 99 wore nine gold beads. Burial 86 wore ten agate beads, glass beads, four bronze bangles and a bronze ring. There were also two lumps of clay. Clay was regularly found in the late Bronze and early Iron Age graves at Ban Non Wat, and could indicate either an interest in pottery making or dying fabric. A large enclosed kiln was found in the same part of the site as this burial. Burial 104 contained a bird's egg, again matched at Iron Age Noen U-Loke and Ban Non Wat. Two cowrie shells were associated with burial 93. Other offerings comprised a bronze anklet, bimetallic rings, an Anadara marine shell, one bead of carnelian and a spindle whorl.

\section{Mortuary phase 3}

Burials of the third mortuary phase were linked through their common association with walls and floors which are interpreted as residential buildings. The graves are set out in rows, on an identical orientation as the walls, and were often found to have been cut through the floors within. The proportion of infants fell to $42 \%$ of the sample. Of the adults, there was a preponderance of males, with eight against just two females. There was also one adult of unknown sex.

There was a singular uniformity about the adult mortuary ritual (Figures 21, 26). Graves were laid out on a northwest to southeast axis. Associated ceramic vessels continued to comprise globular cord marked pots and open bowls. Most were accompanied by an iron sickle and an iron knife. The former had been hafted with a wooden handle, traces of which have survived. Knives had been contained in a sheath fashioned from broad, woven fibre of some sort (Figure 38). To a background of uniformity, there were some individual characteristics. A young man in burial 62 wore a gold ring. Burial 49 had the only bivalve shell. The woman in burial 75 wore 21 bronze finger rings. Bronze ornaments were more abundant than in previous phases and one man, burial 82 , wore two bronze belts with a circular cross section identical in form to those found in two male Iron Age 3 graves at Noen U-Loke (Figure 26). Burial 68, another male, might 


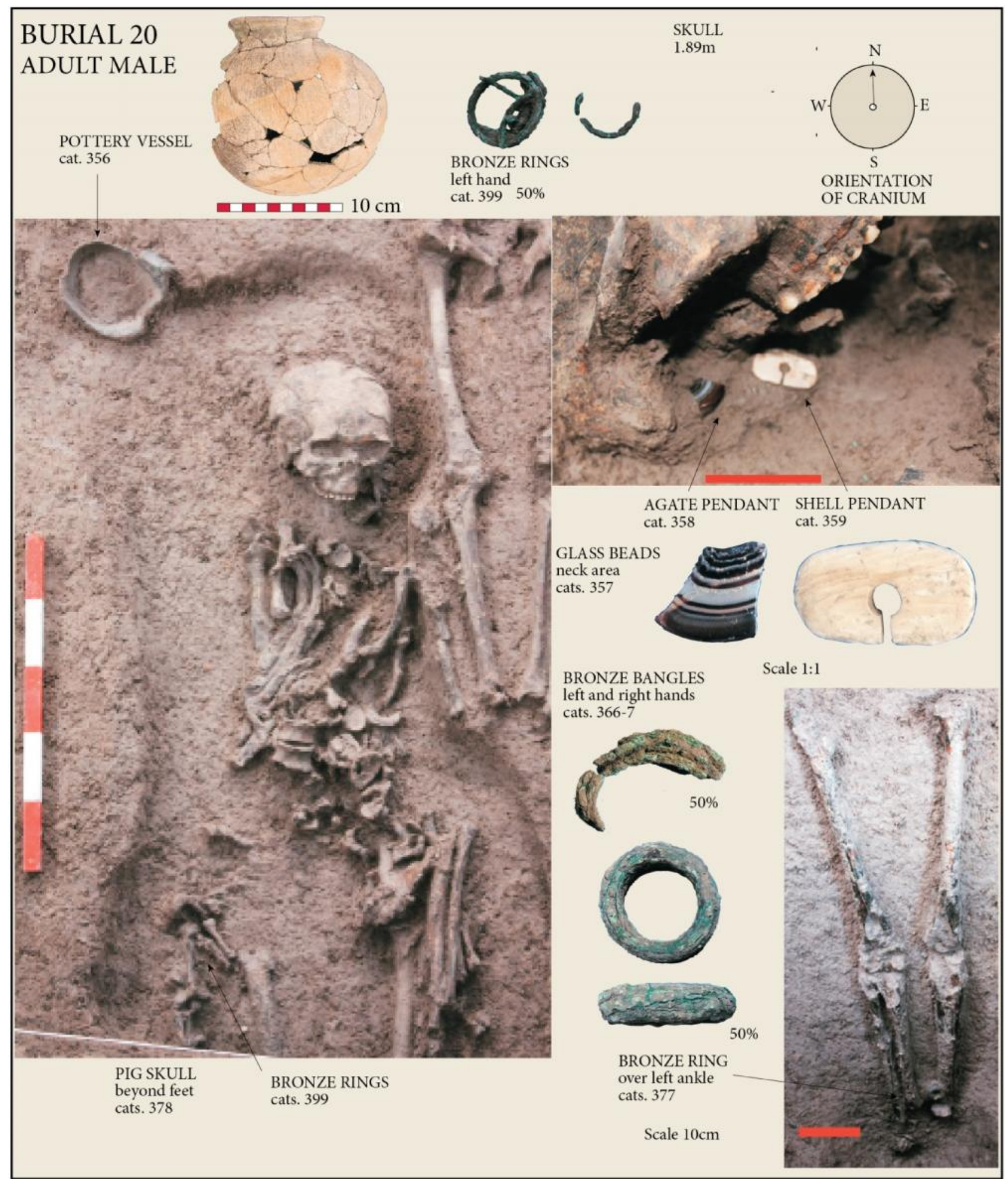

Figure 24: Burial 20, an adult male, was found at a depth of $1.89 \mathrm{~m}$, with the body orientated on a north to south axis. The dead person wore a bronze bangle on each wrist, and around the neck, an agate and a shell pendant. A pottery vessel might have been associated, and it is found to the right of the cranium. Glass beads were located in the neck area and were presumably strung as a necklace. Beyond the excavated area, a pig's cranium and a bronze toe ring were recovered. 


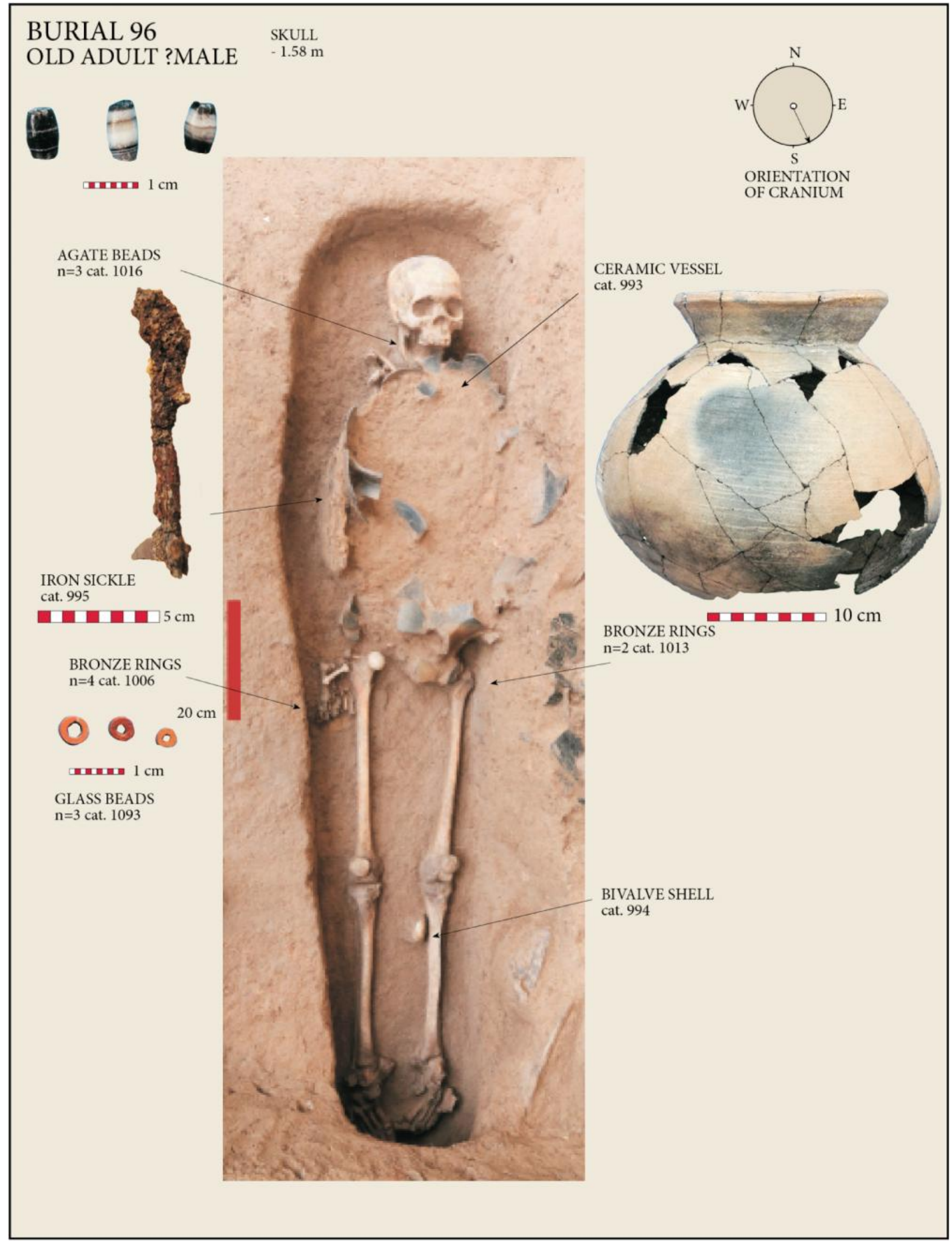

Figure 25. Burial 96 of mortuary phase 2 contained the skeleton of old adult, probable male, with the head oriented SSE. The skull was found at a depth of $1.58 \mathrm{~m}$ below datum. There were few grave goods. A pottery vessel on the abdomen had been cut through when a large posthole was driven through the grave. There was an iron sickle alongside the right upper arm, bronze rings on each hand and a bivalve shell inside the left instep. Three glass beads were also associated. 


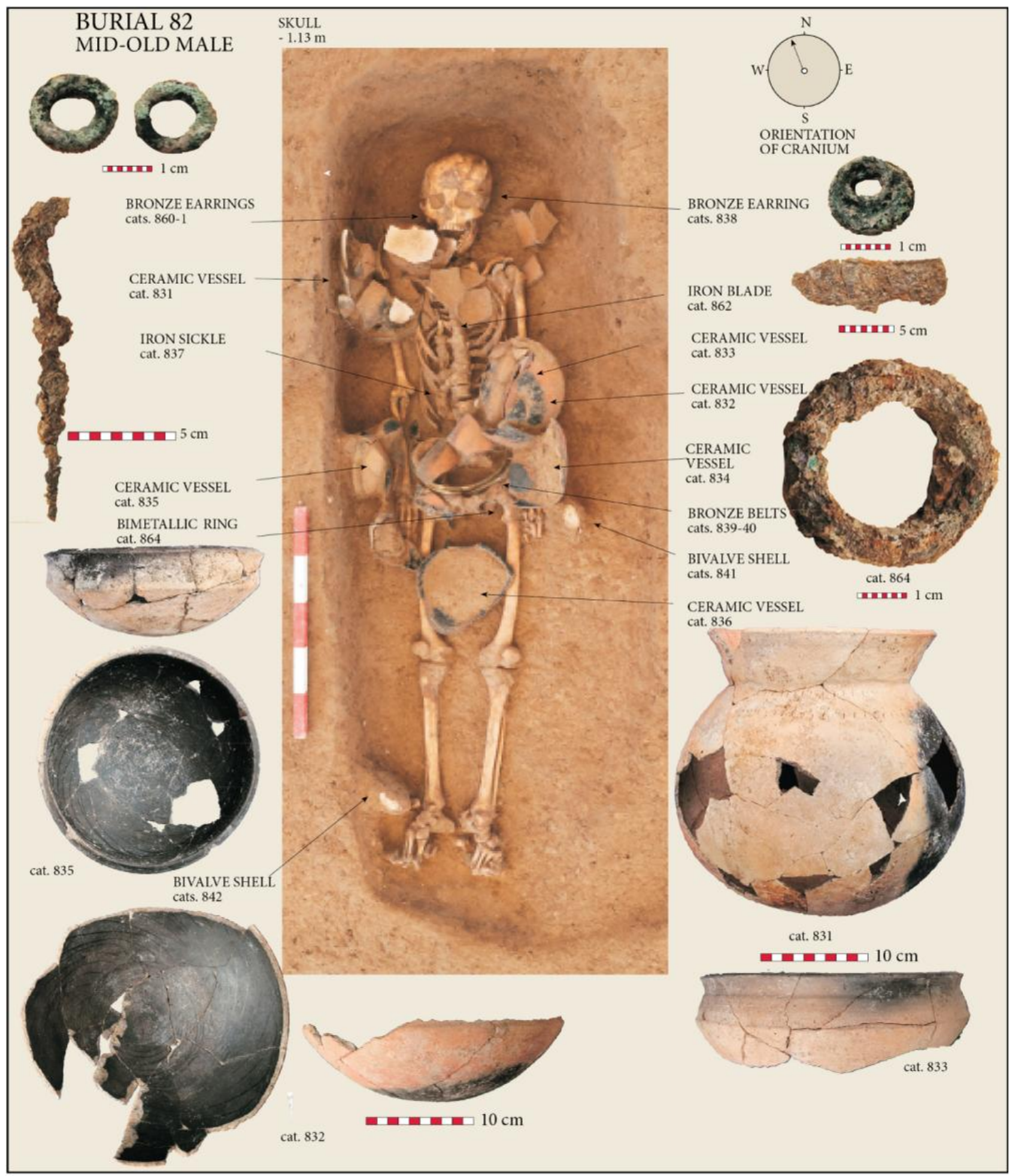

Figure 26: Burial 82 was a mid to old male of Mortuary Phase 3, found at a depth of 1.13m below datum with the head oriented NNW. It is the richest interment of mortuary phase 3 and was sealed under a clay floor. He was accompanied by six pottery vessels disposed over the upper body. He wore two bronze belts, of a form paralleled at Noen U-Loke, where two men wore three and four such belts respectively. Other bronzes included three earrings and one bimetallic ring of bronze and iron. Two bivalve shells had been placed with the corpse, one by the right ankle and the other by the left hand. An iron sickle was found over the upper body, and an iron knife blade on the upper chest. The radiocarbon determination for a bivalve shell from this burial places it in the $4^{\text {th }}$ century AD. According to the dimensions of his belt, this man had a waist measurement of about $63 \mathrm{~cm}$ (25").

well have been a potter, since he was interred with a lump of clay and a burnishing stone. Unfortunately, burial 46 had been badly disturbed and only the foot bones were intact. This man wore 43 bronze anklets. Glass beads were extremely rare, and animal bone offerings also notable for their near absence. Pseudomorphic remains of wo- 
Table 5: The finds associated with intact adult burials of mortuary phase 2

\begin{tabular}{llllll}
\hline Burial & 57 & 84 & 96 & 105 & 108 \\
\hline Sex & $\mathrm{F}$ & $\mathrm{F}$ & $? \mathrm{M}$ & $\mathrm{M}$ & $\mathrm{M}$ \\
Age & Old & Old & Old & Old & Old \\
Orientation & $\mathrm{N}$ & $\mathrm{NW}$ & $\mathrm{SE}$ & $\mathrm{E}$ & $\mathrm{SE}$ \\
Pots & 2 & 3 & 1 & 0 & 1 \\
Bronze bangle & 0 & 1 & 0 & 1 & 4 \\
Bronze finger ring & 0 & 1 & 6 & 0 & 0 \\
Bronze ring & 0 & 1 & 0 & 0 & 0 \\
Iron sickle & 0 & 0 & 1 & 0 & 0 \\
Iron knife & 1 & 0 & 0 & 0 & 0 \\
Iron fragment & 0 & 0 & 0 & 1 & 0 \\
Bimetallic ring & 0 & 1 & 0 & 0 & 0 \\
Glass bead & 1 & $\mathrm{p}$ & $\mathrm{p}$ & 0 & 0
\end{tabular}

$\begin{array}{llllll}\text { Agate bead } & 1 & 1 & 3 & 1 & 0 \\ \text { Bivalve shell } & 0 & 1 & 1 & 1 & 0 \\ \text { Spindle whorl } & 0 & 0 & 0 & 2 & 0\end{array}$

ven fabric on some of the bronze ornaments suggest that the dead were either interred wearing clothing, or were covered by a shroud (Figure 38 ).

Two of the infants of MP3 were buried with the head in one ceramic vessel, and the feet in another. This is matched by a burial on the eastern mound, and by burial 9 at Noen U-Loke. The pottery vessels at both sites are identical in form. Burial 73, a child aged about 3-4 years at death, was interred like the adults, supine with the head to the southeast. The two associated pots again conform to the norm for this site, a globular cord-marked form, and an open bowl. This group of infants had few associated offerings. Eight intact graves shared five bronze rings, two earrings, one toe ring and two bronze bangles. There was an iron point, two bimetallic rings and an iron ring. Unlike previous infants, glass beads were absent.

Table 6: The finds associated with the infant burials from mortuary phase 2

\begin{tabular}{|c|c|c|c|c|c|c|c|c|c|c|c|c|c|c|c|c|}
\hline Burial number & 79 & 52 & 83 & 86 & 90 & 91 & 93 & 94 & 95 & 97 & 99 & 100 & 101 & 103 & 104 & 107 \\
\hline Pottery vessel & 0 & 0 & 0 & 2 & 1 & 1 & 5 & 0 & 2 & 1 & 1 & 1 & 3 & 1 & 2 & 3 \\
\hline Bronze bangle & 0 & 0 & 0 & 4 & 9 & 9 & 0 & 0 & 0 & 0 & 0 & 0 & 0 & 0 & 0 & 0 \\
\hline Bronze ring & 0 & 0 & 0 & 1 & 8 & 0 & 0 & 0 & 0 & 0 & 0 & 0 & 0 & 0 & 0 & 0 \\
\hline Bronze earring & 0 & 0 & 0 & 0 & 0 & 3 & 0 & 0 & 0 & 0 & 0 & 0 & 0 & 0 & 0 & 0 \\
\hline Bronze anklet & 0 & 0 & 0 & 0 & 0 & 0 & 1 & 0 & 0 & 0 & 0 & 0 & 0 & 0 & 0 & 0 \\
\hline Bronze fragment & 0 & 0 & 0 & 0 & 0 & 0 & 0 & 0 & 0 & 0 & 0 & 0 & 0 & 1 & 0 & 0 \\
\hline Bimetallic ring & 0 & 0 & 0 & 1 & 2 & 0 & 3 & 0 & 6 & 0 & 0 & 0 & 0 & 0 & 0 & 0 \\
\hline Bivalve shell & 0 & 2 & 0 & 0 & 0 & 0 & 0 & 0 & 1 & 0 & 0 & 0 & 0 & 0 & 0 & 0 \\
\hline Marine shell & 0 & 0 & 0 & 0 & 0 & 0 & 1 & 0 & 0 & 0 & 0 & 0 & 0 & 0 & 0 & 0 \\
\hline Cowrie shell & 0 & 0 & 0 & 0 & 0 & 0 & 2 & 0 & 0 & 0 & 0 & 0 & 0 & 0 & 0 & 0 \\
\hline Egg & 0 & 0 & 0 & 0 & 0 & 0 & 0 & 0 & 0 & 0 & 0 & 0 & 0 & 0 & 1 & 0 \\
\hline Carnelian beads & 0 & 0 & 0 & 0 & 0 & 0 & 0 & 1 & 0 & 0 & 0 & 0 & 0 & 0 & 0 & 0 \\
\hline Glass beads & 0 & 0 & 0 & $\mathrm{p}$ & $\mathrm{p}$ & $\mathrm{p}$ & $p$ & $\mathrm{p}$ & $p$ & 0 & 0 & 0 & 0 & 0 & $\mathrm{p}$ & 0 \\
\hline Agate beads & 0 & 0 & 0 & 10 & 0 & 0 & 0 & 0 & 0 & 0 & 0 & 0 & 0 & 0 & 0 & 0 \\
\hline Gold beads & 0 & 0 & 0 & 0 & 0 & 0 & 0 & 0 & 0 & 0 & 9 & 0 & 0 & 0 & 0 & 0 \\
\hline Spindle whorl & 0 & 0 & 0 & 0 & 0 & 0 & 0 & 0 & 0 & 0 & 0 & 0 & 0 & 0 & 0 & 0 \\
\hline Clay & 0 & 0 & 0 & 2 & 0 & 0 & 0 & 0 & 0 & 0 & 0 & 0 & 0 & 0 & 0 & 0 \\
\hline
\end{tabular}


Table 7. The burials associated with intact adults burials of mortuary phase 3

\begin{tabular}{|c|c|c|c|c|c|c|c|c|c|c|}
\hline Burial & 49 & 62 & 68 & 71 & 72 & 75 & 76 & 77 & 81 & 82 \\
\hline Sex & Male & ?Male & Male & Male & Male & Female & Female & Male & Male & Male \\
\hline Age & Mid adult & $\begin{array}{l}\text { Young } \\
\text { adult }\end{array}$ & Adult & Mid adult & $\begin{array}{l}\text { Young-mid } \\
\text { adult }\end{array}$ & Adult & Mid-old adult & Mid-old adult & $\begin{array}{l}\text { Mid } \\
\text { adult }\end{array}$ & Mid-old \\
\hline Orientation & N & $S$ & NW & SE & NW & SE & NW & SE & SE & NW \\
\hline Pots & 2 & 1 & 1 & 2 & 4 & 2 & 3 & 2 & 2 & 6 \\
\hline Bronze earring & 3 & 0 & 0 & 0 & 1 & 1 & 1 & 1 & 0 & 3 \\
\hline Bronze bangle & 2 & 3 & 0 & 3 & 0 & 1 & 6 & 4 & 9 & 0 \\
\hline Bronze finger ring & 6 & 3 & 0 & 3 & 2 & 21 & 5 & 3 & 2 & 0 \\
\hline Bronze ring & 0 & 0 & 0 & 0 & 0 & 0 & 0 & 1 & 0 & 0 \\
\hline Bronze belt & 0 & 0 & 0 & 0 & 0 & 0 & 0 & 0 & 0 & 2 \\
\hline Iron sickle & 1 & 0 & 0 & 1 & 1 & 1 & 1 & 1 & 1 & 1 \\
\hline Iron knife & 2 & 1 & 0 & 1 & 2 & 0 & 1 & 1 & 1 & 1 \\
\hline Bimetallic ring & 1 & 0 & 0 & 0 & 0 & 0 & 1 & 1 & 1 & 1 \\
\hline Gold ring & 0 & 1 & 0 & 0 & 0 & 0 & 0 & 0 & 0 & 0 \\
\hline Red ochre & 0 & 0 & 0 & 0 & 4 & 0 & 1 & 0 & 0 & 0 \\
\hline Clay & 0 & 0 & 1 & 0 & 1 & 0 & 0 & 0 & 0 & 0 \\
\hline Burnishing stone & 0 & 0 & 1 & 0 & 0 & 0 & 0 & 0 & 0 & 0 \\
\hline Bivalve shell & 1 & 0 & 0 & 0 & 0 & 0 & 0 & 0 & 1 & 0 \\
\hline Animal bone & 0 & 0 & 0 & 0 & 0 & 0 & 1 & 1 & 0 & 0 \\
\hline Glass beads & 0 & 0 & 0 & 0 & $\mathrm{p}$ & 0 & 0 & $\mathrm{p}$ & 0 & 0 \\
\hline $\mathrm{p}$ : present & & & & & & & & & & \\
\hline
\end{tabular}

Table 8: The finds with mortuary phase 3 infants

\begin{tabular}{lcccccccc}
\hline Burial & 24 & 25 & 47 & 58 & 73 & 74 & 78 & 80 \\
\hline Pottery vessel & 3 & 3 & 1 & 2 & 2 & 4 & 2 & 3 \\
Bronze ring & 0 & 0 & 0 & 0 & 0 & 2 & 0 & 5 \\
Bronze ear ring & 0 & 0 & 0 & 0 & 2 & 0 & 0 & 0 \\
Bronze toe ring & 0 & 0 & 0 & 0 & 1 & 0 & 0 & 0 \\
Bronze bangle & 0 & 1 & 0 & 0 & 1 & 0 & 0 & 0 \\
Bimetallic ring & 1 & 1 & 0 & 0 & 0 & 0 & 0 & 0 \\
Iron point & 0 & 0 & 0 & 1 & 0 & 0 & 0 & 0 \\
Pig bone & 0 & 0 & 0 & 0 & 0 & 1 & 0 & 0 \\
Iron ring & 0 & 0 & 0 & 0 & 0 & 1 & 0 & 0 \\
\hline
\end{tabular}

\section{Mortuary phase 4}

The burials of MP4 are confined to the western part of the excavated area (Figure 22). Being so close to the modern ground surface, some have been disturbed. There are two male, two female and two adult graves, together with the remains of six infants. Infants thus comprise $50 \%$ of the sample. The definition for MP4 graves, is that they overlie the clay walls and floors associated with the preceding phase. The mortuary ritual continued virtually unaltered. The orientation remained the same save for one adult found with the head pointing to the south. The same range of ceramic vessels were found, although some of the open bowls now had a footed base. Burial 65 included an iron sickle, and iron knives were found with three of the four intact adults. Two were also interred with spindle whorls. Bronzes were rare, with just five finger rings. Burial 69 wore a gold coiled earring.

Two of the four infants were buried with the head and feet within pottery vessels of the same form as those associated with MP3. The infant in burial 66 wore an ornament of 11 glass beads, but other mortuary goods were rare, comprising two bronze bangles, seven bronze ear rings, and iron bangle, iron point and a clay counter. This set of burials belongs to the very end of the prehistoric period as currently known in the upper Mun Valley with 


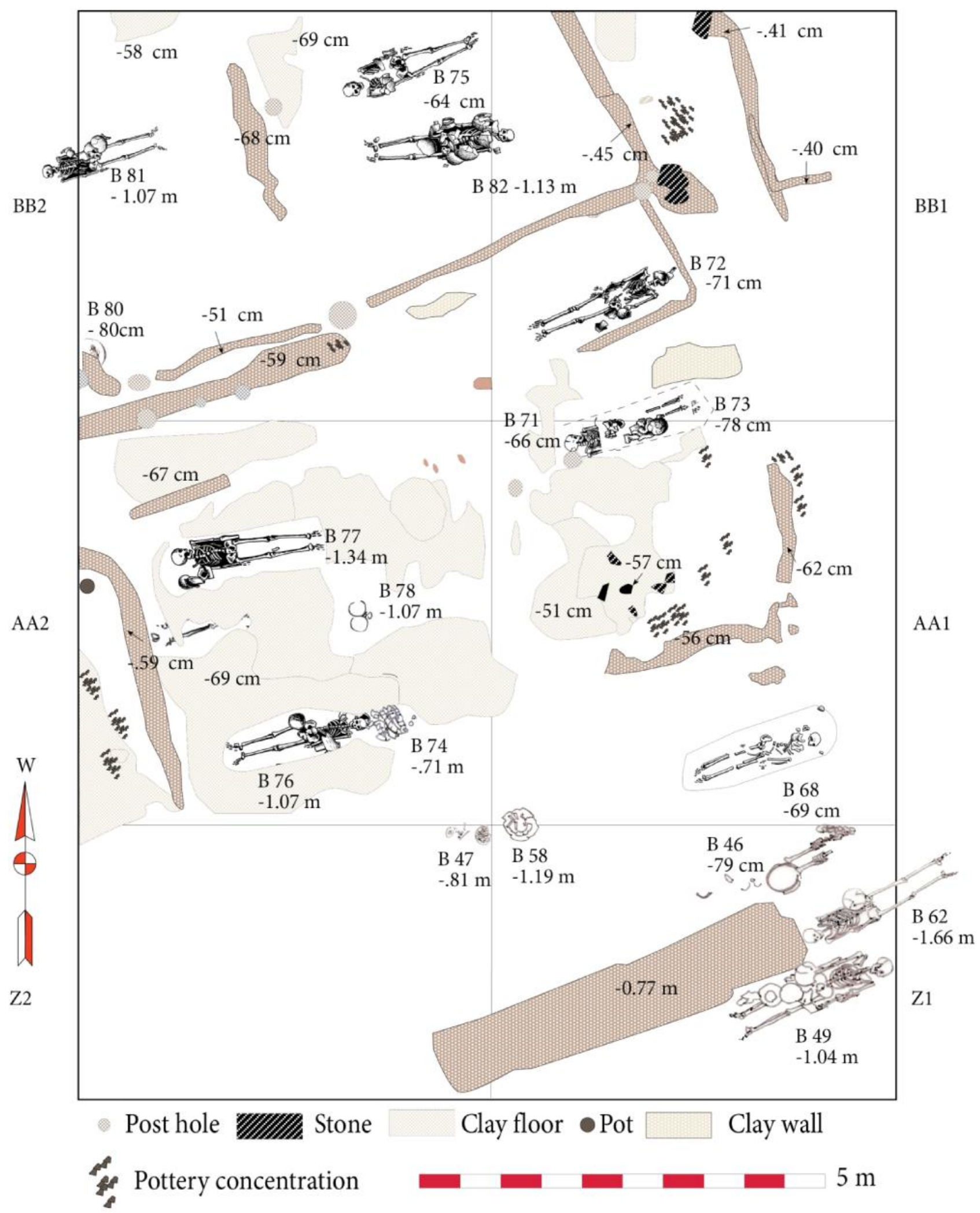

Figure 27: The distribution of features in layers 1:4 to 2:2 showing the burial of MP3 individuals within residential buildings.every likelihood that they overlap with the establishment of the Dvaravati civilization in Central Thailand. 
Table 9: The finds associated with intact adult burials of mortuary phase 4

\begin{tabular}{lcccc}
\hline Burial & 38 & 45 & 65 & 69 \\
\hline Sex & ?female & & female & male \\
Age & mid adult & adult & mid adult & old adult \\
Orientation & NW & S & NW & SE \\
Pots & 2 & 4 & 1 & 3 \\
Bronze finger ring & 0 & 4 & 1 & 0 \\
Iron sickle & 0 & 0 & 1 & 0 \\
Iron knife & 1 & 0 & 1 & 1 \\
Iron ring & 0 & 0 & 0 & 1 \\
Gold earring & 0 & 0 & 0 & 1 \\
Red ochre & 1 & 0 & 0 & 0 \\
Spindle whorl & 3 & 1 & 0 & 0 \\
Clay & 0 & 0 & 0 & 3 \\
Shell bead & 0 & 0 & 0 & 1 \\
\hline
\end{tabular}

The western burials: summary

The nature of the mortuary rituals at Non Ban Jak requires a detailed assessment of the relationships between human burials on the one hand, and the structural evidence on the other. The latter comprises the foundations of walls and the associated floors. Walls were made from clay and wooden posts, the latter probably being the framework of studs to support wattle and daub walls. The floors were made of white or red clay, and some show evidence for burning. These walls and floors were also associated with evidence for occupation in the form of broken pottery vessels, faunal remains, concentrations of shellfish and clay-lined hearths. In the 2012 season, one hearth area within a residence was associated with large quantities of carbonised rice. Due to the rebuilding of houses over the foundations of earlier structures, the latter were often disturbed in prehistory, and the remains survive in a badly damaged condition. Table 7: The finds associated with intact adults burials of mortuary phase 3This is seen just over the surface of the hard, laterite natural substrate in square AA1, where wall fragments lie at a depth of 1.97 to $2.03 \mathrm{~m}$ below datum. Burial 108 overlies these, the base of the grave lying at a depth of $1.87 \mathrm{~m}$. The burial is intact, and was laid out on the same orientation of the walls found at a higher level. In turn, this burial was covered by a clay floor and fragmentary wall foundations, the former barely $4 \mathrm{~cm}$ above the human bones. It is considered unlikely that this conjunction is fortuitous, and more likely that the covering of the grave with a floor was a deliberate act reflecting interment within a residential or possibly a dedicated mortuary structure.
The distribution of burials in lower layer 1 and upper layer 2 (Figure 27) takes the form of two rows. When the configuration of walls and floors is superimposed, a pattern emerges whereby the burials align with the walls, and cut through floors. The relative depths of the floors and the walls against that of the graves suggest that the burials were located within these structures. Moreover, the floors contain concentrations of pottery sherds and faunal remains suggesting that they were occupied as houses. Hence, there is a serious likelihood that as in the first season of excavations at this site, the Iron Age inhabitants followed the practice of residential burial.

Table 10: The finds associated with infants of mortuary phase 4

\begin{tabular}{lccccc}
\hline Burial & 37 & 39 & 66 & 70 & 109 \\
\hline Pottery vessels & 2 & 3 & 4 & 2 & 1 \\
Bronze bangle & 0 & 2 & 0 & 0 & 0 \\
Bronze ear ring & 0 & 7 & 0 & 0 & 0 \\
Iron bangle & 0 & 0 & 1 & 0 & 0 \\
Iron point & 0 & 1 & 0 & 0 & 0 \\
Glass beads & 0 & 0 & 11 & 0 & 0 \\
Clay counter & 0 & 0 & 1 & 0 & 0 \\
& & & & & \\
\hline
\end{tabular}

\section{THE MORTUARY OFFERINGS}

\section{Ceramic vessels}

The pottery vessels in adult burials from the successive mortuary phases show little variation over time (Figure 28). The commonest form was a globular vessel with a restricted neck and everted rim. These are very similar to the village cooking pots seen today, and one found with burial 84 of MP2 contained carbonised rice grains. The second common form is an open bowl. These all fall into the Phimai Black tradition, the interiors being decorated with designs imparted with a burnishing stone. With MPs 3 and 4, some of these bowls were given a pedestalled base. The regular conjunction in burials of the two forms suggests that one contained food, and the other was used in life as a platter for eating from.

The vessels from infant burials fall into two groups. Large, lidded pots were used to contain the bodies. Cordmarked globular pots and open bowls were often placed with the dead infant (Figure 29). The form of most burial jars was similar during MPs 1 and 2, while those from the two later phases differed. MPs 1 and 2 also included different forms for containing dead infants. One from MP 1 has a restricted neck and flared rim, while a particularly fine vessel from MP 2 was burnished all over the outer surface.

\section{Iron and bronze artefacts}

Iron at Non Ban Jak was forged into tools and ornaments, but there is very little evidence for weaponry. The con- 


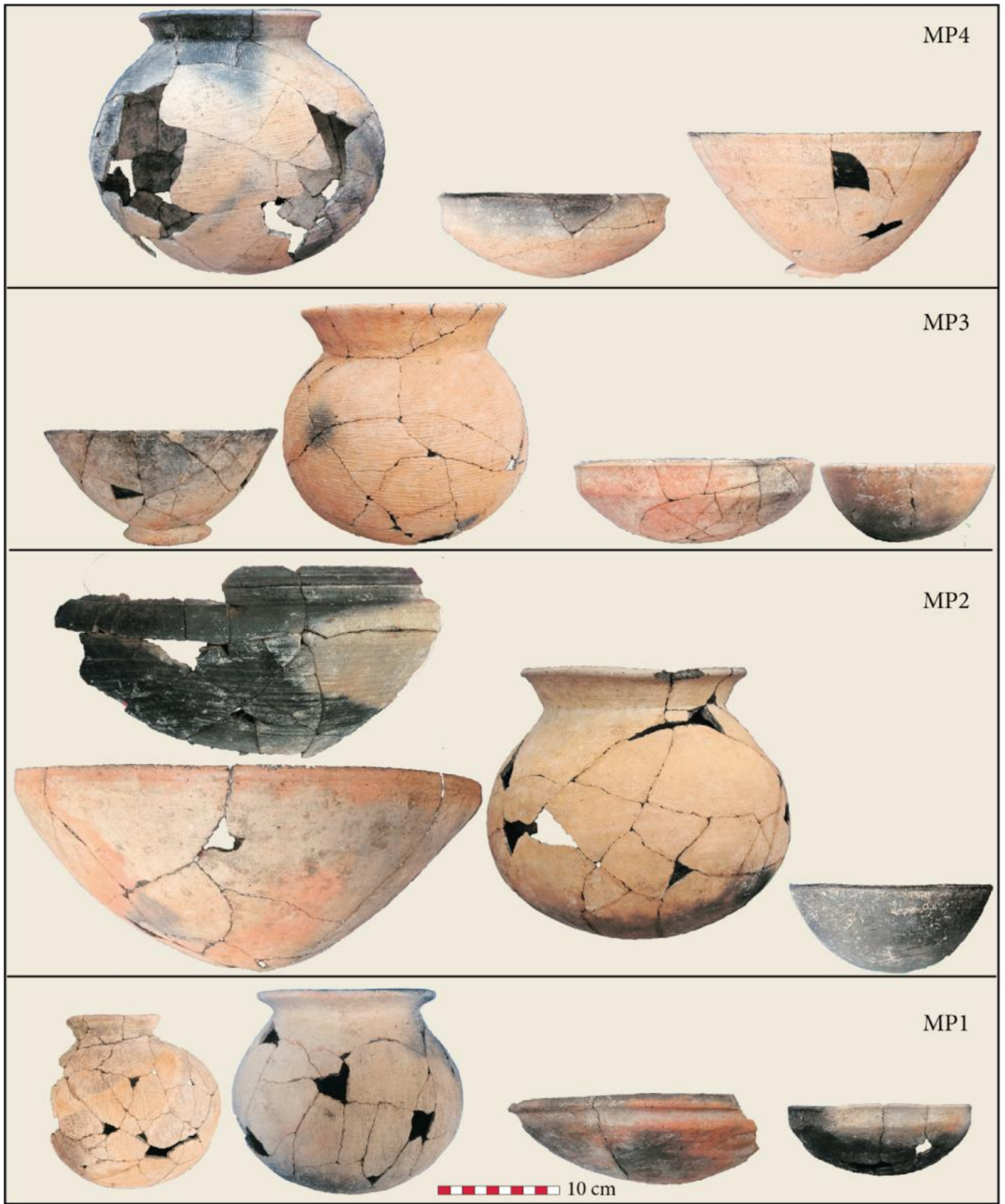

Figure 28: Ceramic vessels from adult burials.

centration of iron slag in the eastern mound indicates local ironworking but it is too early to be sure whether this represents smelting or smithing. The issue of the local exploitation or otherwise of laterite ore also needs further study (Cawte and Boyd 2010; Pryce and Natapintu 2009).
Tools are dominated by the pairing of a socketed sickle with a ridged knife (Figure 30), both of which recur in identical form in the later contexts at Noen U-Loke. Socketed hoes, which were found in the earlier Iron Age at Ban Non Wat, are absent. However, it is known that large socketed ploughshares were in use during this peri- 


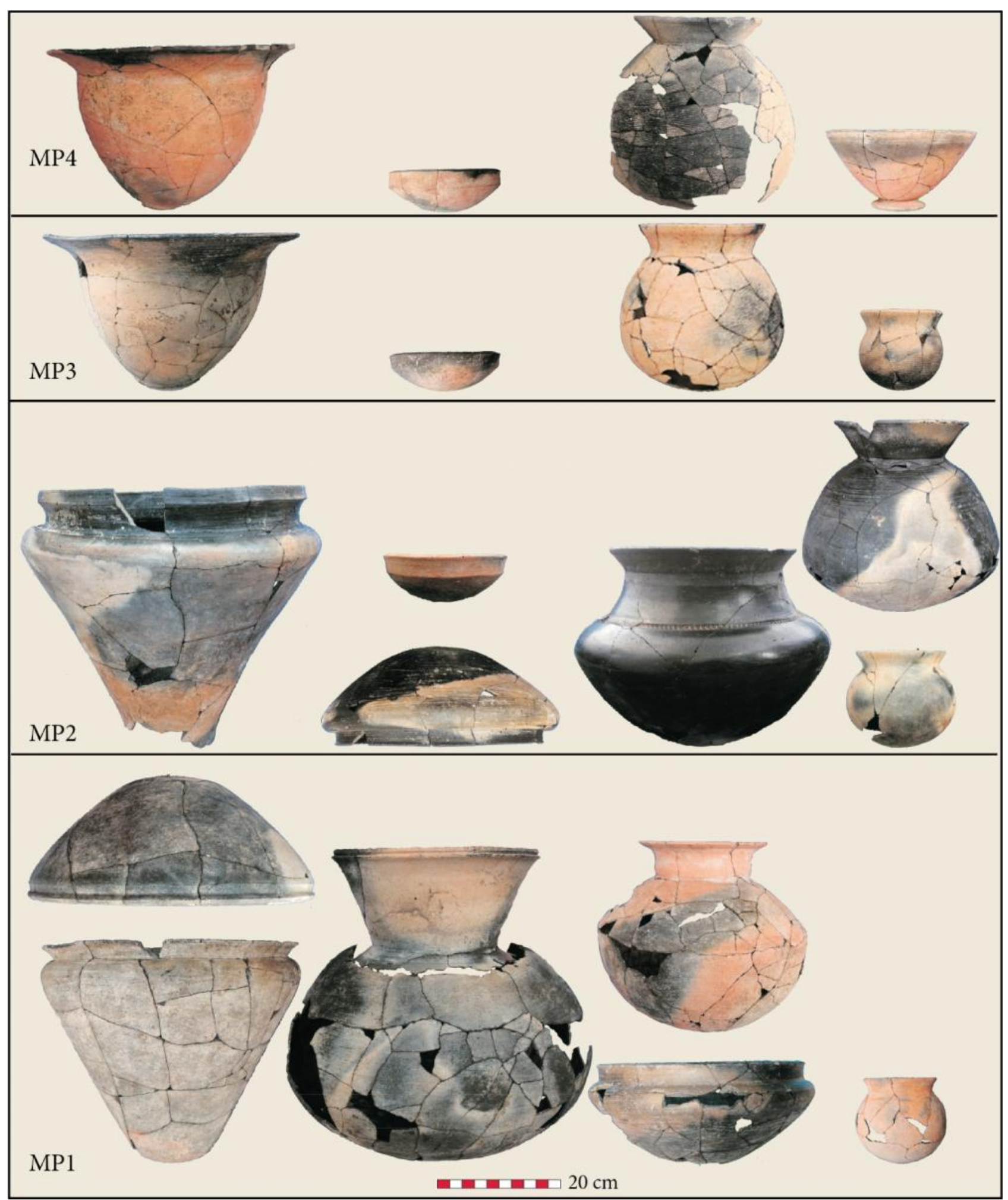

Figure 29: Ceramic vessels from infant burials.

-od at Non Ban Jak following the discovery of one in a kiln in the eastern mound excavation. There is one sickle in MP2 graves, and they became regular offerings in those of MPs 3-4. They are so consistently present in MP3-4 that it seems highly likely that this social group was closely involved in rice cultivation.
Rings made of bronze and iron were absent from MP1 and 4 graves, but common with MP 2-3, when at least 15 were recovered from the intact graves of the former, and seven with the latter. Two iron bangles were found with a MP1 infant, an iron ring with MP3 and a further bangle in MP4. 


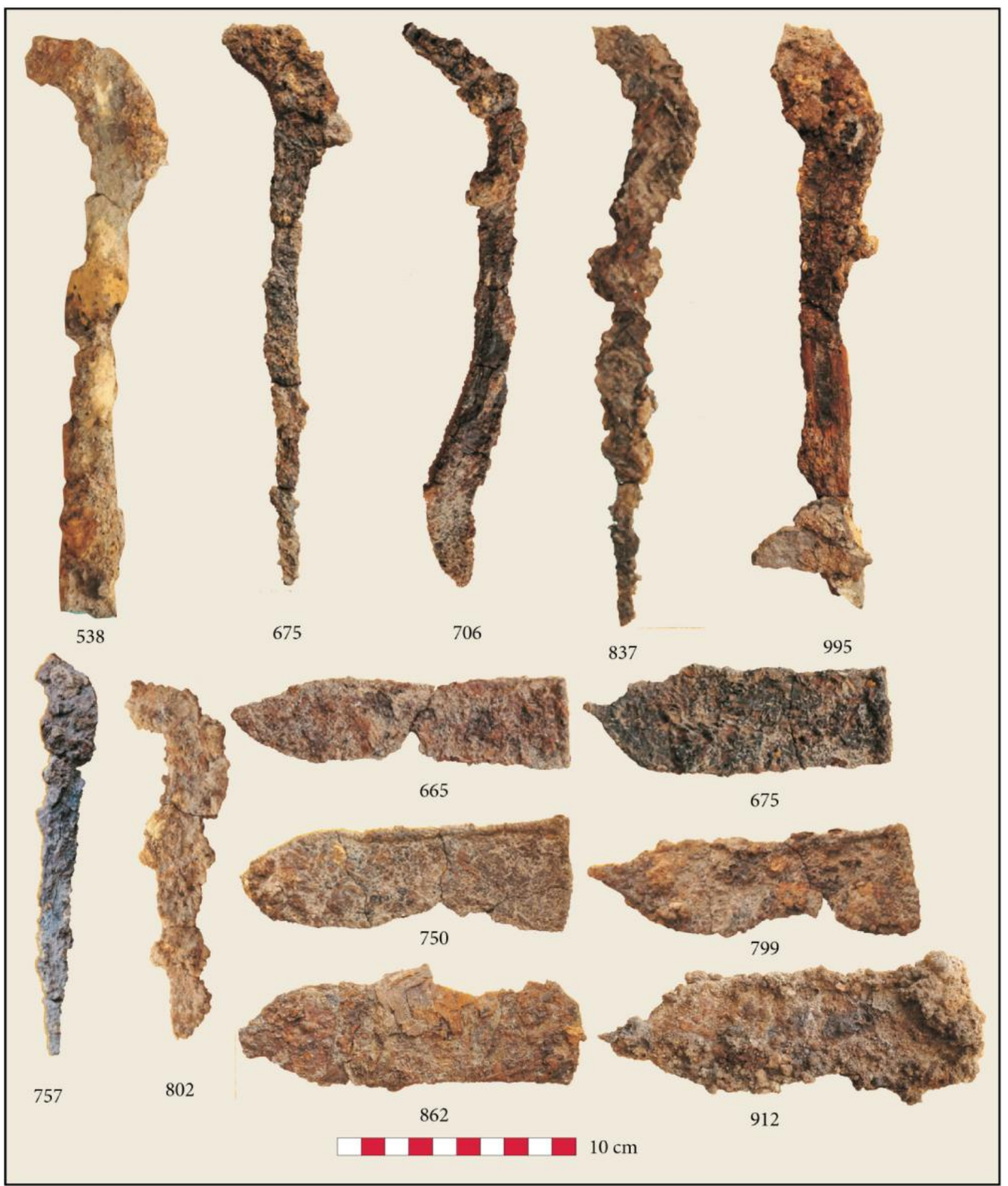

Figure 30: Iron sickles and knives from Non Ban Jak burials.

Bronze was employed for a variety of ornaments, particularly bangles and rings for the fingers, ears and toes. The man in MP3 burial 82 wore two belts, and the MP1 infant burial 32 wore three, each having the same type of fastening device as was seen on those at Noen U-Loke (Figure 31). Intact burials from MP1 contained 48 bangles, six anklets, three belts, and a single ear, finger and toe ring. For MP2, there were 28 bangles, three earrings, seven finger rings and 10 rings of unknown location on the body. There were also many bronze ornaments in MP3 burials: 30 bangles, 12 ear rings, 45 finger rings, two belts and a toe ring. The numbers fell away, albeit with fewer overall burials, in MP4, with two bangles, seven ear rings and five finger rings. These figures pale before the 


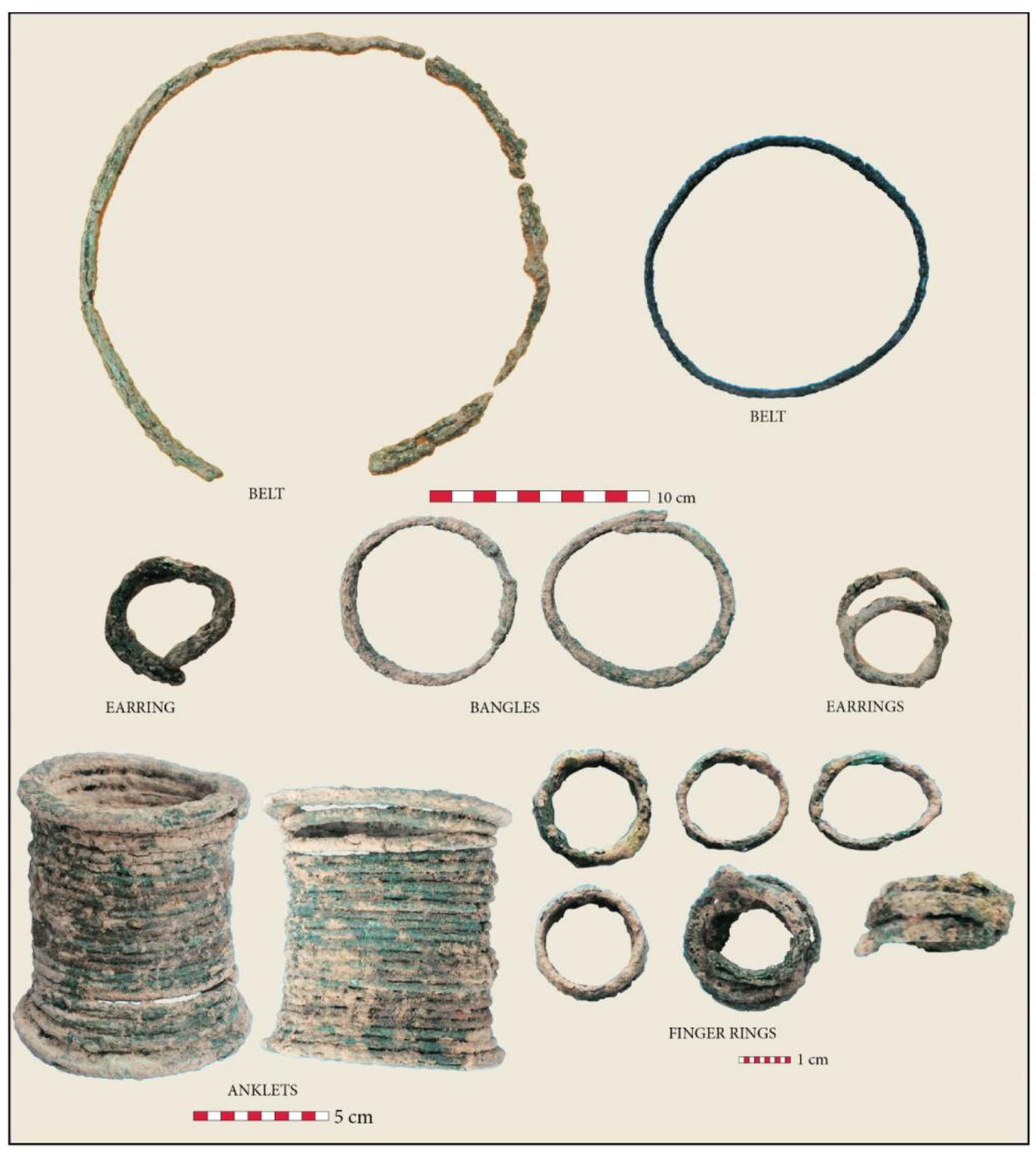

Figure 31: Bronze ornaments from Non Ban Jak burials.

wealth in bronze jewellery associated with IA 3 and IA 4 individuals at Noen U-Loke.

The same situation obtains for other ornaments. While the range is similar to later burials at Noen U-Loke, including gold, silver, carnelian, agate and glass, the quantities are far less. Two unusual ornaments from Non Ban Jak are the marine shells pierced for suspension, a gold finger ring and gold spiraliform earring (Figure 32).

\section{Non mortuary pottery vessels}

Pottery vessels were recovered from three non-mortuary contexts. The first, a regular characteristic for the Iron Age of the upper Mun Valley, is the placement of lidded bowls in ritual contexts, such as the corners of a room in which burials were located. Complete pots were also found in kilns, or associated with one of the kilns as wasters. The third context is purely domestic, for example in a 


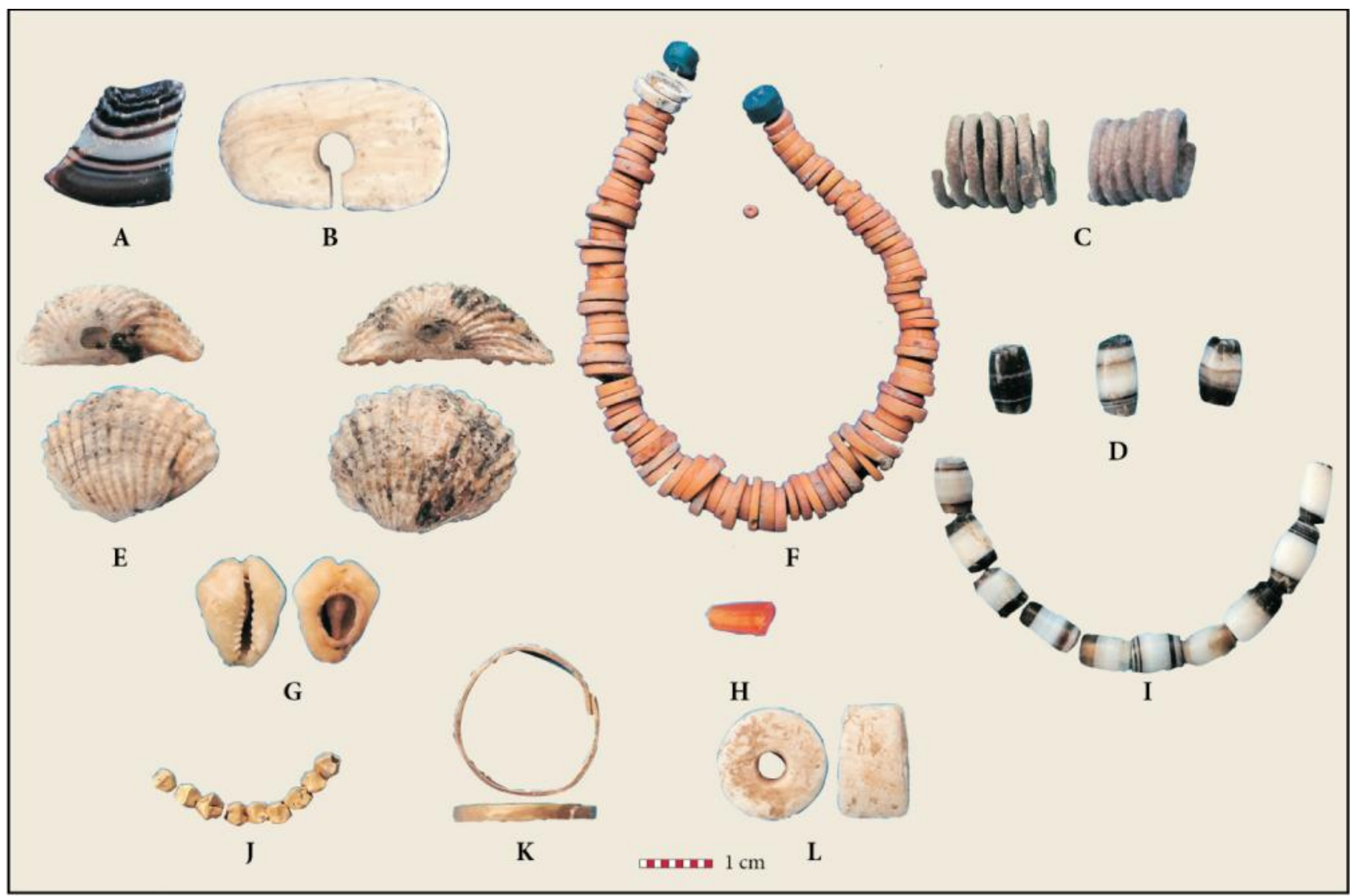

Figure 32. Ornaments from Non Ban Jak burials. A. agate pendant, burial 20 EP1; B. shell pendant, burial 20 EP1; C. silver ear coils, burial 64 EP1; D. agate beads, burial 96, MP2; E. Anadara shell pendants, burial 59, MP2; F. glass beads, burial 22 MP1; G. cowrie shell, burial 93 MP2; H. carnelian bead, burial 95 MP2; I. agate beads, burial 86, MP2; J. gold beads, burial 99 MP2; K. gold finger ring, burial 62, MP3; L. shell bead, burial 69 MP4.

burnt and abandoned kitchen, or pits located just outside a residence.

Pottery vessels from the two kilns in the eastern square have been reconstructed. The circular kiln contained eight pots (Figure 33). One of these was regularly used in the first two mortuary phases for interring infants. All the other forms were also employed as mortuary offerings, and broken specimens were also recovered from ritual and occupation contexts. The smaller of the eastern mound kilns was oval in shape, and contained a single very large vessel (Figure 34). While not identical, it does resemble the mortuary pot containing burial 32 which was located on the western mound. Several pots were also reconstructed from those found as kiln rake out from the larger of the two eastern mound kilns. Again, they are similar in form to those found in graves as mortuary offerings. To judge from the quantity of collapsed clay daub covering each kiln, it is suggested that the kilns themselves were enclosed by a domed body constructed of daub liberally tempered with rice straw. Two of the kilns had been employed to fire a single, very large vessel. The other was still filled with pots of different forms. The closed nature of the kilns could well explain how the typical late Iron Age pots were so often fired in a reducing atmosphere. We do now know of any other Iron Age kilns in the Mun Valley, and certainly the firing technolo- gy differs markedly from that seen in most potting villages today.

Ritual deposits comprising a lidded pot were first identified at Non Muang Kao and Noen U-Loke. At Non Ban Jak, their relationship to mortuary areas is clearly defined. These are very finely decorated with pattern burnished designs on the interior (Figure 35). Three sets were found in the surviving three corners of the chamber found on the eastern mound with three burials within (Figures 11-12). Others have been found in the vicinity of buildings and burials, albeit in the case of the latter, not within the grave itself.

A selection of the pots from occupation contexts that could be reconstructed reveals similarity in form to those placed with the dead. One vessel, cat. 269 in figure 36, was found in the kitchen area of a house on the eastern mound, and was clearly used for cooking.

\section{THE SPINDLE WHORLS AND TEXTILES}

Most of the 35 spindle whorls recovered were made from fired clay, with a few manufactured from bone or turtle carapace. They were used to extend the length and tensile strength of fibres. Five burials (B26, B38, B64, B102, $\mathrm{B} 105)$ contained whorls as mortuary offerings. The rest came from occupation contexts. The presence of whorls in all phases of the site reveals technological continuity 


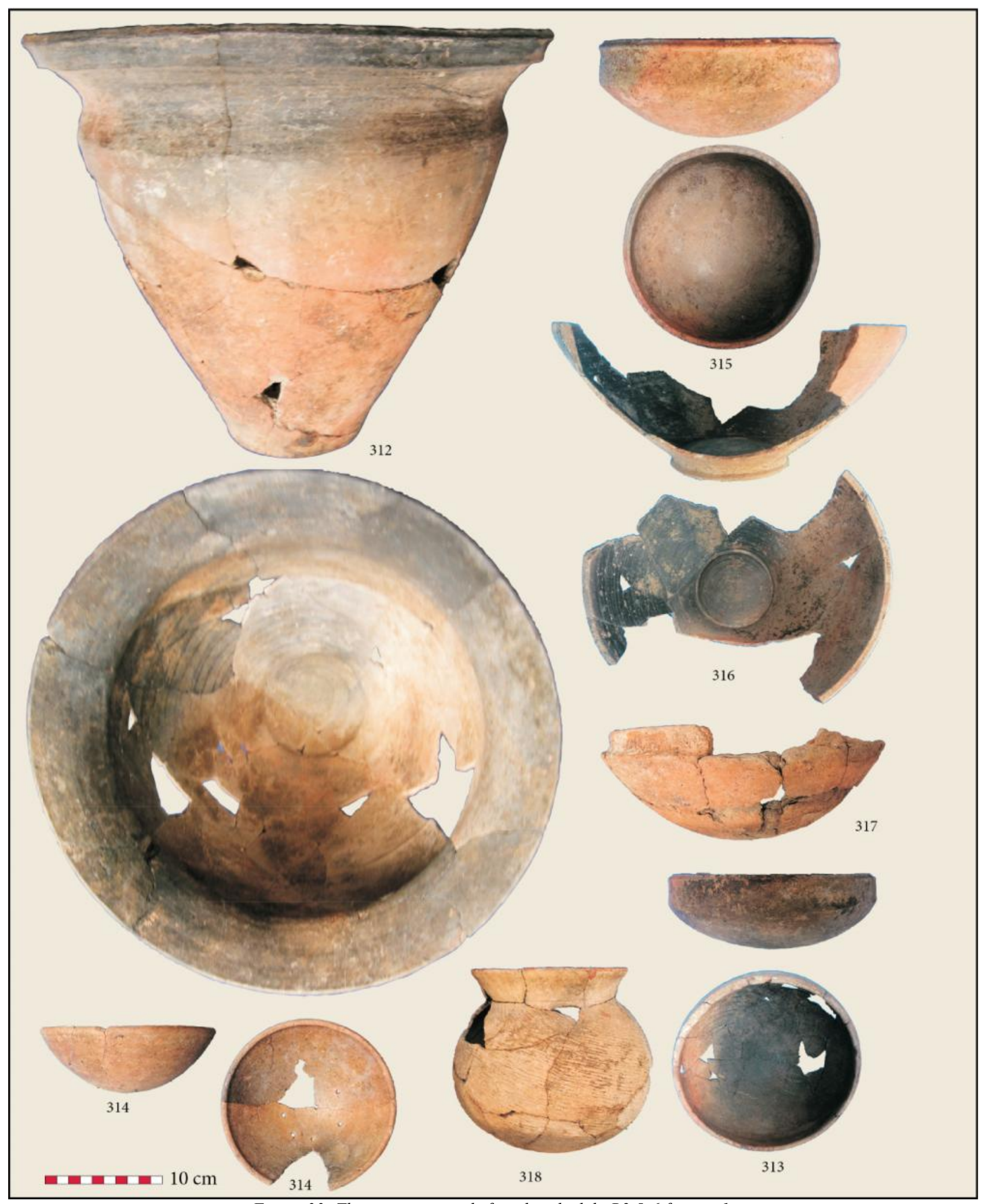

Figure 33: The ceramic vessels found in the kiln B2 5:6 feature 1.

from the Bronze Age contexts seen at Ban Non Wat through to the late Iron Age. However, the relatively small number of such specialised tools at Non Ban Jak might suggest small-scale household production of textiles. Over a thousand whorls were recovered from Ban
Non Wat, only $8 \mathrm{~km}$ to the east. If this is not a function of the greater area excavated, it could be seen as the result of more intense, specialized manufacture of cloth. The energy invested in cloth production at Non Ban Jak is more comparable with that seen during the final Iron Age at 


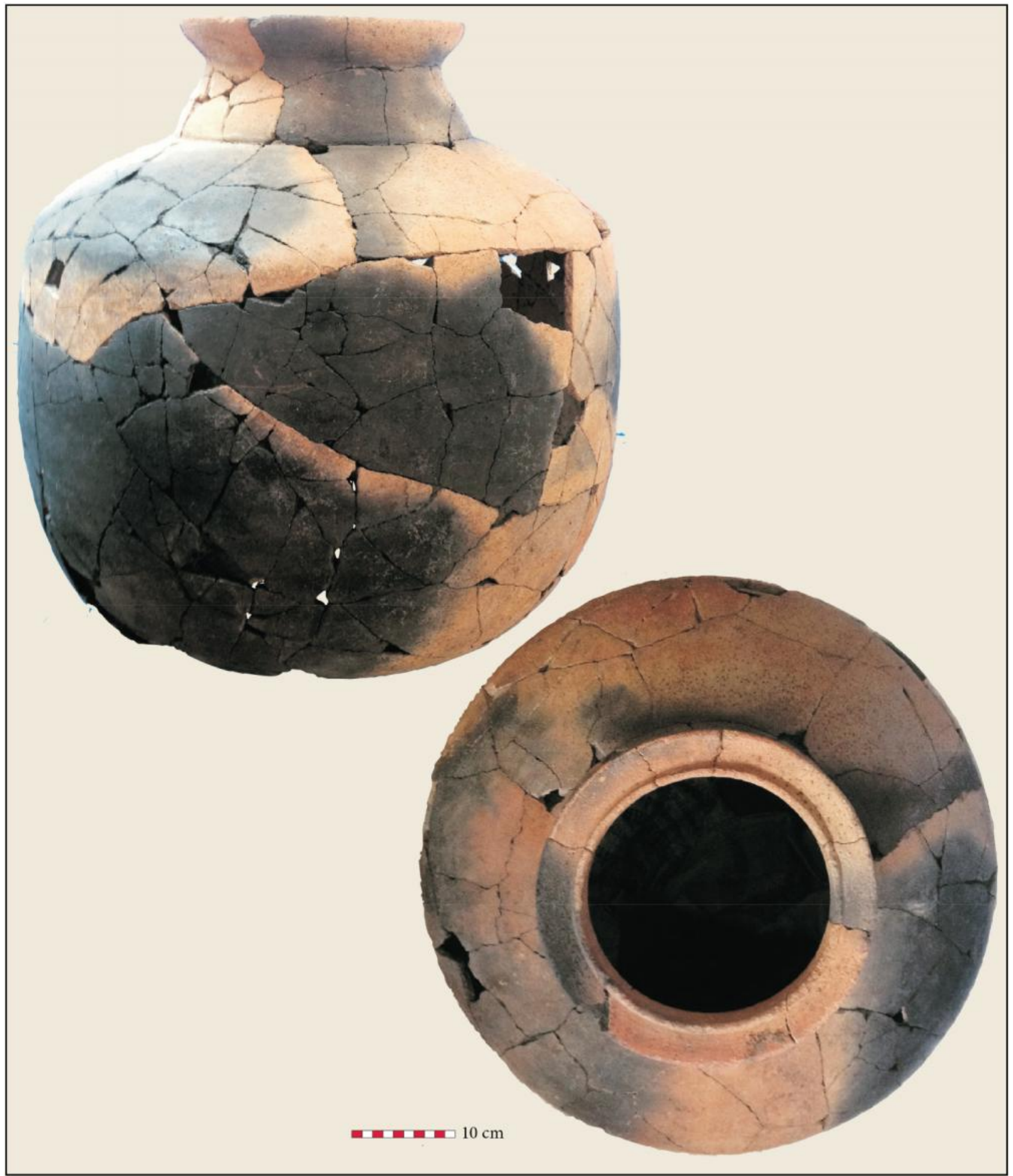

Figure 34: The ceramic vessel found inside the kiln in B1 5 surface of 2 feature 1.

Noen U-Loke. The functional attributes of the tools from both these sites are very similar.

Cat. 5 is the most striking whorl in the Non Ban Jak assemblage (Figure 37A). This atypical whorl type, in the form of a door knob, comes from a late context, dated to the $6^{\text {th }}$ to the $8^{\text {th }}$ century AD. While not widely paralleled in Southeast Asia, it is also seen in the late Iron Age buri- als at Tha Kae in Central Thailand. Whorls of this type first occur at South Indian archaeological sites on prehistoric trade routes where they were found with iron spindles (Cameron 2011). This exotic form points to Indian contact. It is also far from coincidental that basic flat disc whorls from the upper layers are appreciably lighter than those from earlier sequences, and would have been better 


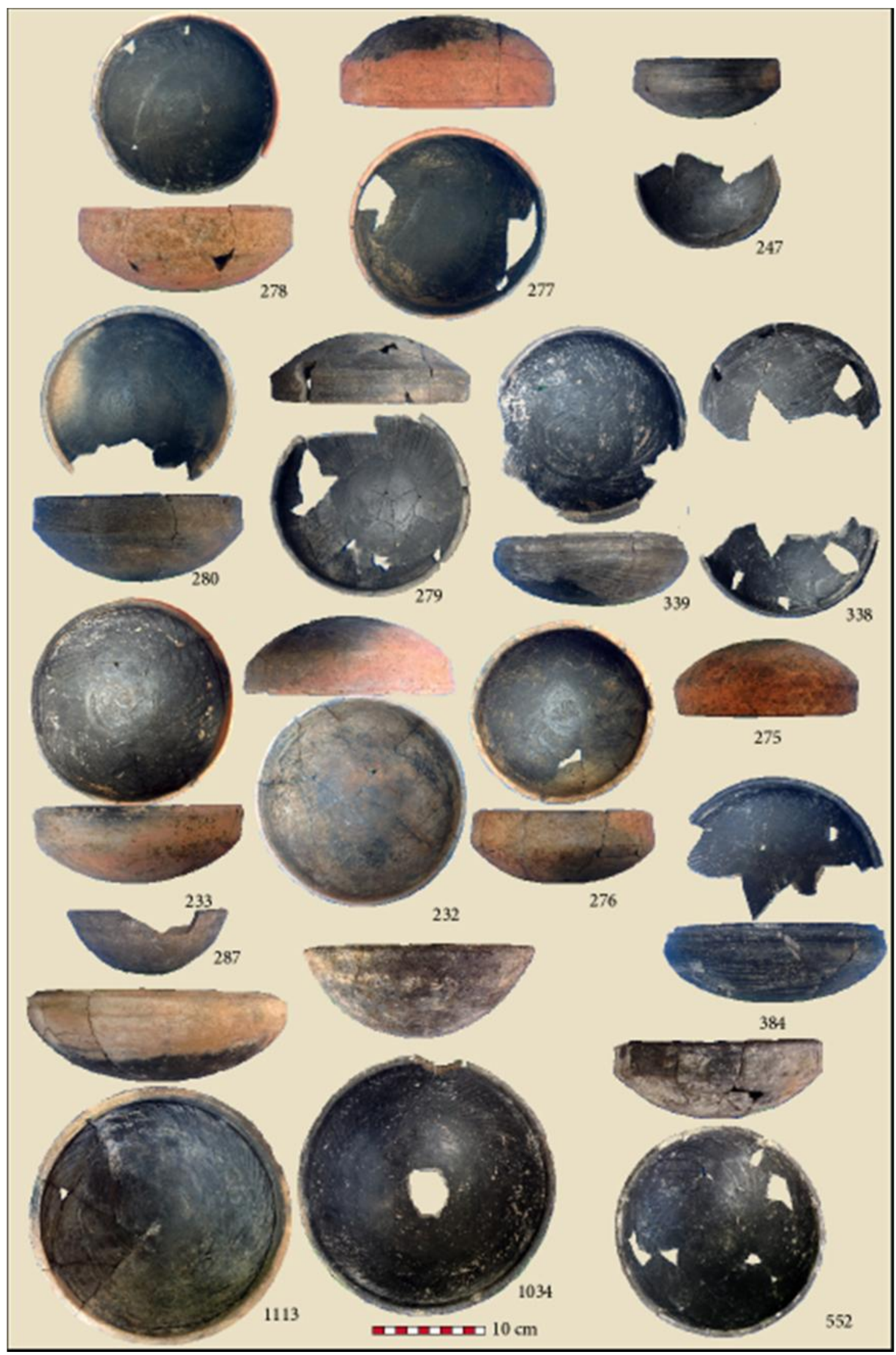

Figure 35: The ceramic vessels from occupation contexts. Cat. 277-8 A2 5:3 F1; cat. 247 B1 5:1 F1; cats. 279-280 B1 5:2; cat. 338 9 X1 3:1 F1; cats. 232-3 A2 4:8 F1; cats. 275-6 A2 5:2A building B; cat. 287 B1 5:4, cat. 284 X1 3:1 F1; cat 1113 AA1 4:3 F6; cat 1034 AA1 4:4 F7; cat 552 X2 3:4 F1. These vessels were commonly found as pairs, lip to lip, placed in strategic parts of buildings 


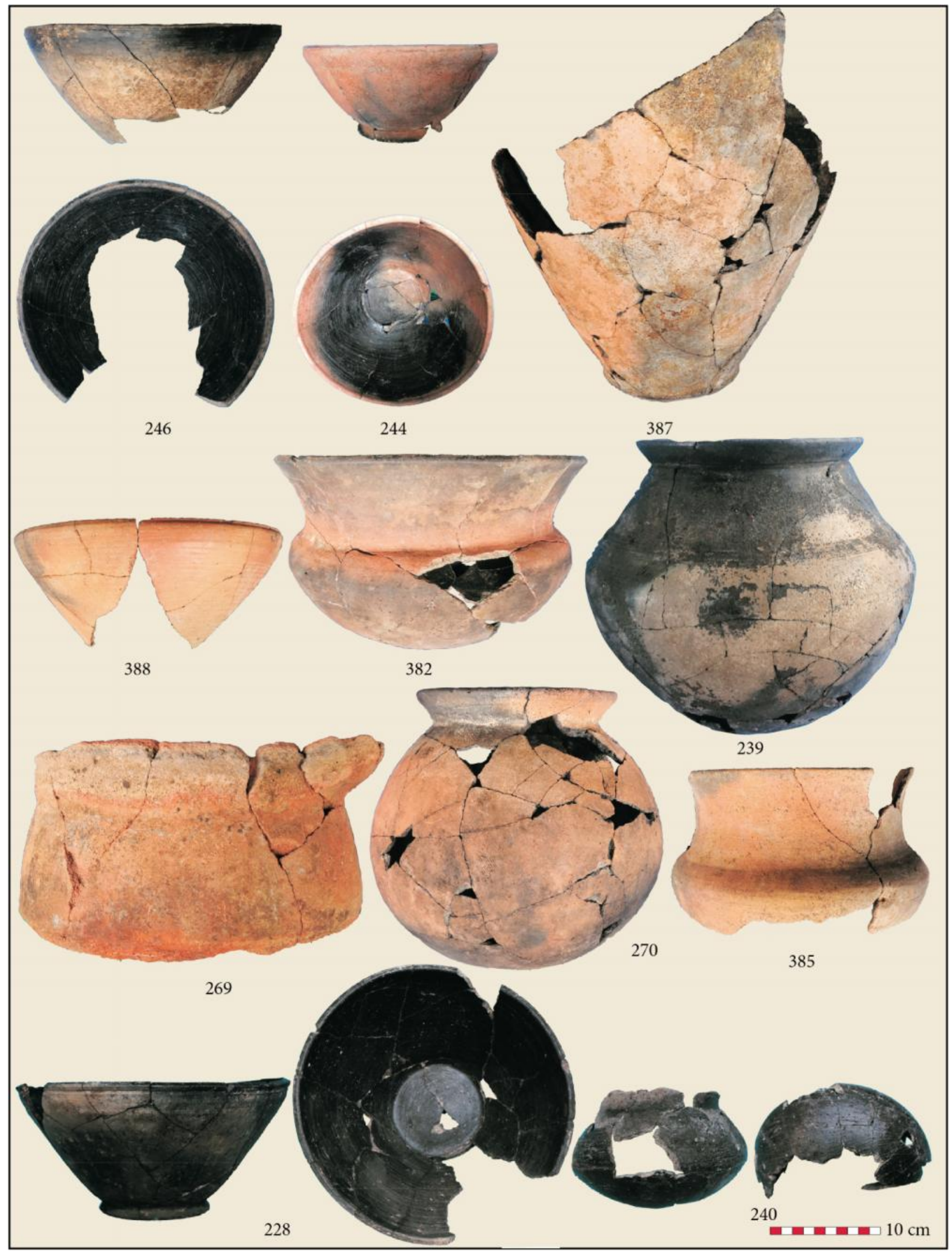

Figure 36: The ceramic vessels from occupation contexts Cat. B1 5:1 F1; cat. 244 B2 5:1 F2; cat. 387 B1 5:6 F1; cat. 388 , cat. 382 B1 6:2 F1; cat. 382 B1 6:2 F1; cat. 239 B2 5:1 F2; cat. 269 B2 5:1, floor of building B; cat. 270 A1 5:1. Cat. 269 is part of a stove found on the burnt floor of building B. cat. 385 B1 5:6 F1, cat 228 B1 4:9 feature 1; cat. 240 B2 5:1 feature 2. 


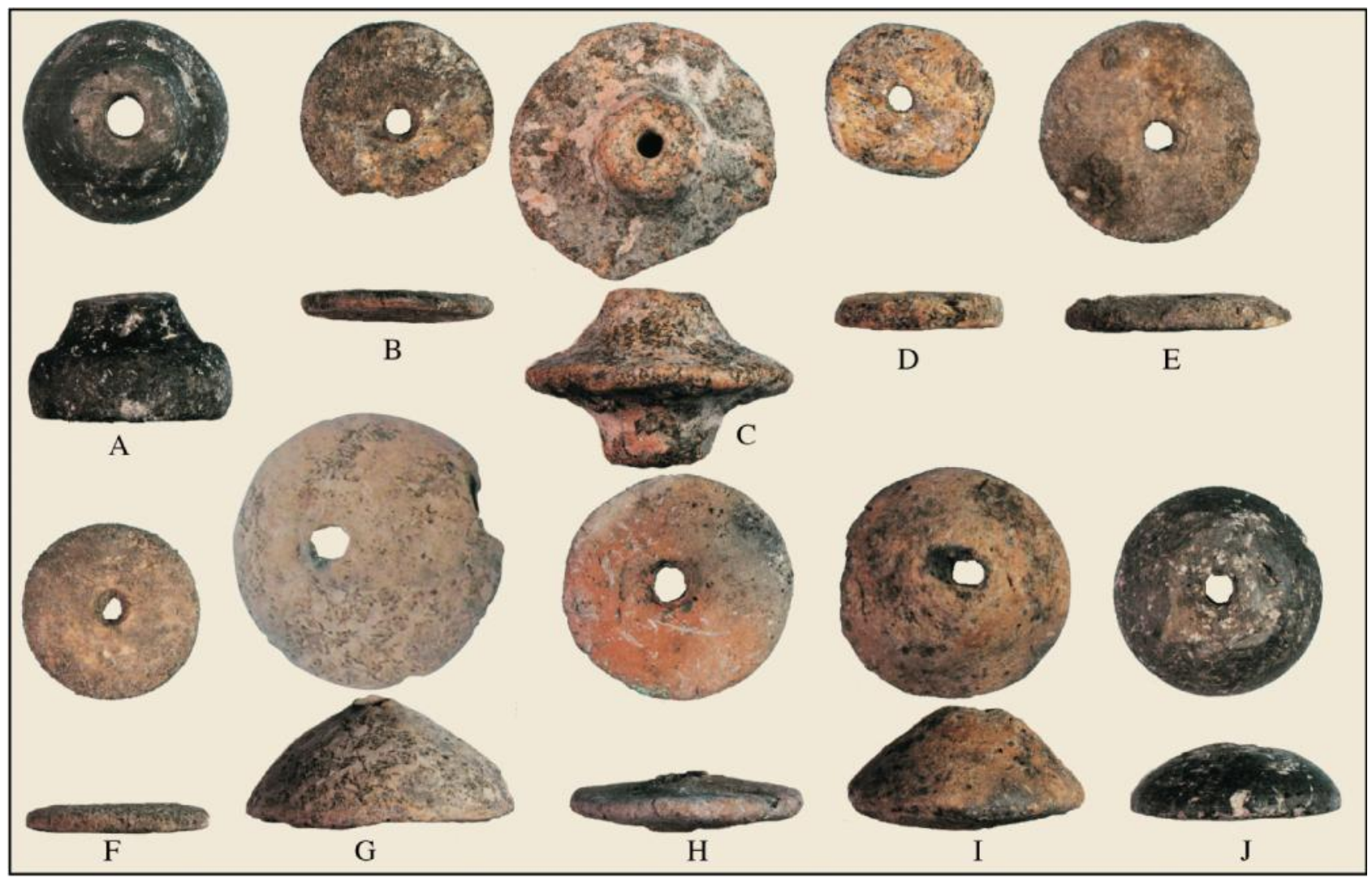

Figure 37: Spindle whorls from Non Ban Jak. A. cat. 5, A2 1-4, B. cat. 117 C. cat. 171, B1 2-1, D. cat 485, burial 38, E. cat. 488, burial 38, F. cat. 489, burial 38, G. cat. 2, B1 2-3, H. cat 617, burial 64, I cat. 328, B1 6-2, J. cat 115, A2 4-3. Scale: diameter 37A is $3 \mathrm{~cm}$.

adapted to spinning lighter fibres - probably cotton (Gossypium spp.), which was also introduced from the Indian subcontinent during this period. The whorl thus joins many other instances of Indian inspiration that had been proceeding for centuries before the occupation of Non Ban Jak, much of it surely through Southeast Asian intermediaries.

Mineralised fabric pseudomorphs as well as coarsely woven scabbards have been identified in the mortuary contexts (Figure 38). Their material and structural composition range from simple plaited bamboo knife scabbard (cat. 655, B.69) to a coarse 1:1 tabby weave fabric (cat. 802 B.76) and a very finely woven warp-faced weave on an iron knife also in B76. The presence of textile pseudomorphs on only one side of certain artefacts suggests the use shrouds or clothing. Those found on both sides of the metal tools and bangles (cat. 788) indicate that the artefacts were probably wrapped in fabric unless post burial movement occurred.

\section{THE BOTANICAL REMAINS}

Preliminary archaeobotanical results came from fourteen contexts at Non Ban Jak. An average of thirty-six plant parts per litre were recovered in the contexts analysed (Table 11). All samples contained rice plant parts and in half of the contexts, rice was the only taxon found.

Initial visual inspection of the samples showed rich deposits of rice grains in specific contexts related to oc- cupation areas including stoves and hearths (context nos. $202,262,269)$. Of particular interest was the collapsed kiln which yielded, tuyères, daub and raked out waste product. Sub-samples from these contexts were taken. The daub is probably a mixture of clay and rice straw (context no. 202). There are samples containing mostly compressed rice husk and some grains and are related to the collapsed kiln (context nos. 188, 214, 254).

The inhabitants at Non Ban Jak were relying on rice as part of their subsistence regime, but were also using the rice processing waste in other activities such as kiln construction, signifying a ready supply of rice production byproducts. The plant remains assemblage shows $83 \%$ of the total is made up of rice plant parts including rice caryopses, husk and spikelet bases (Figure 39). The examination of the rice spikelet base rachilla scars show predominantly domesticated rice. The abscission scars in $96 \%$ of the rice spikelet bases $(n=98)$ had the typical irregular and gouged out depressions found in domesticated rice. This is not surprising considering the age of the site, since the earliest evidence for domesticated rice in Thailand dates to 2000-1500 BC at Khok Phanom Di (Thompson 1996), and other Thai sites that have yielded rice remains dating to the Bronze and Iron Ages have also demonstrated predominantly domesticated rice (Castillo 2011).

The weed assemblage at Non Ban Jak is of considerable interest. Although the contexts examined did not yield abundant wild and weedy species (1\% of total plant remains), one particular context (NBJ 133) contained sever- 


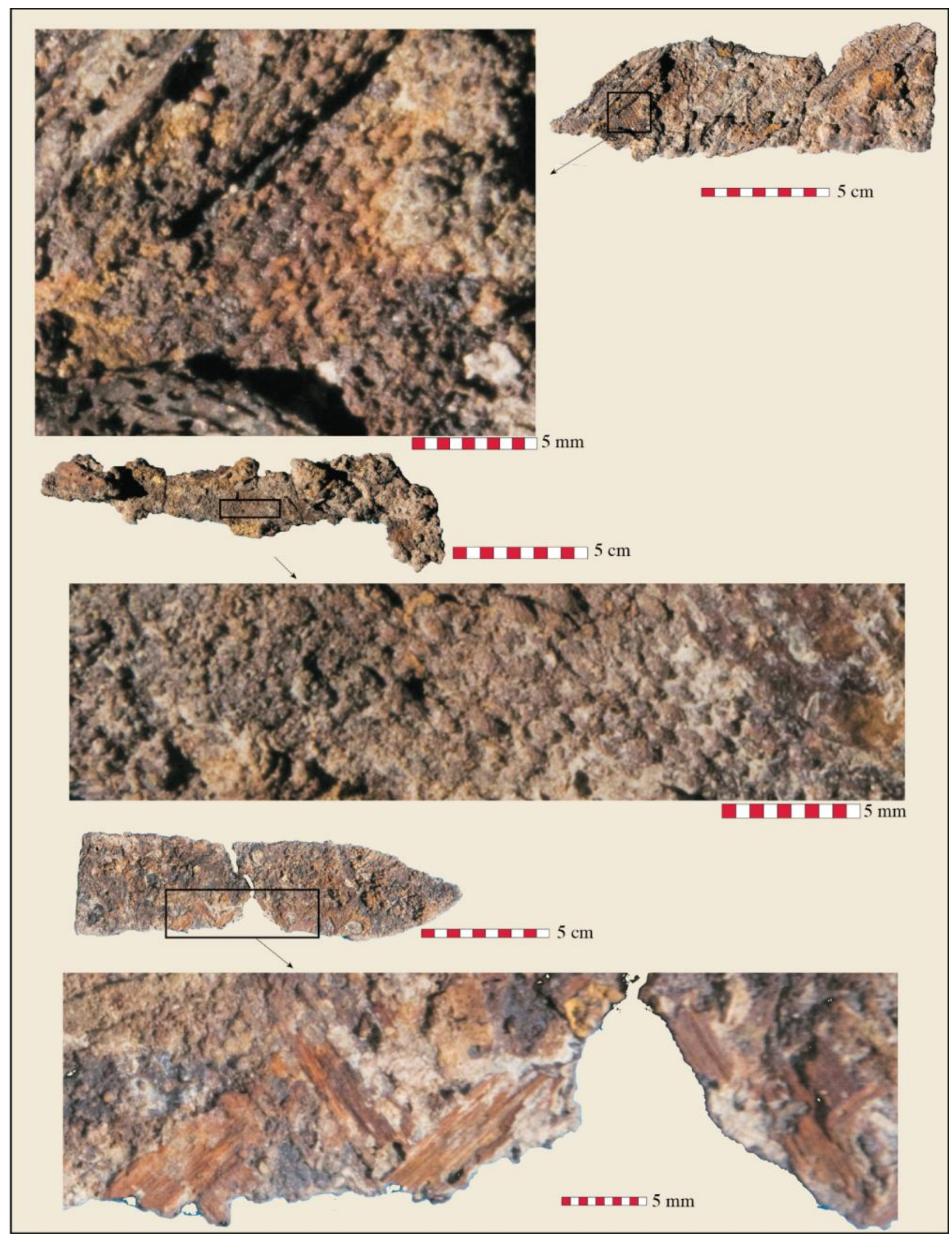

Figure 38: Fabric and a woven scabbard. Top: cat. 799, a knife from burial 76, middle: cat. 802, a sickle from burial 76 and bottom: cat. 655, a knife from burial 69. 


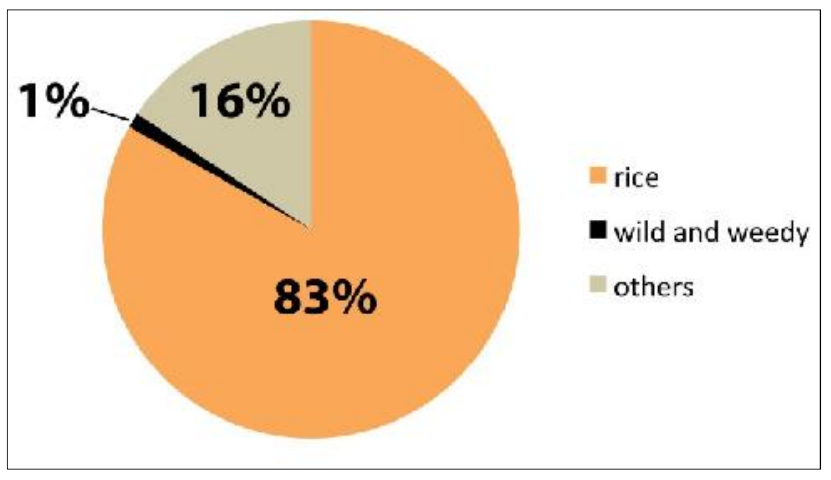

Figure 39: Breakdown of plant remains into main groups.

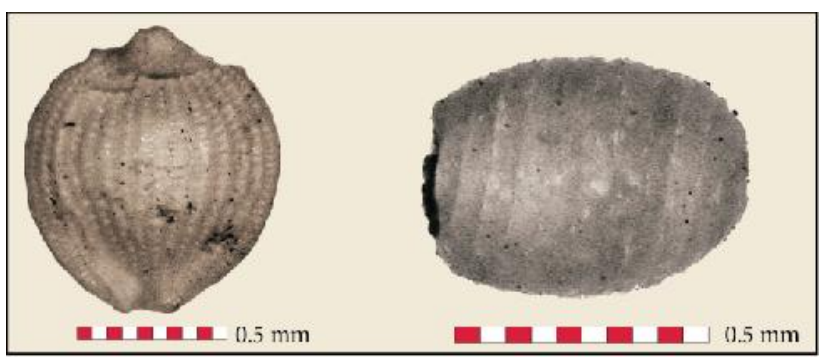

Figure 40. Fimbristylis sp. and Chara zeylanica seeds.

Table 11 Summary statistics of the botanical datasets from flotation in Non Ban Jak season 2012.

\begin{tabular}{|c|c|}
\hline Number of Specimens & 3856 \\
\hline Number of Identified Specimens & 3858 \\
\hline No. of samples & 14 \\
\hline Plant parts per litre MEAN ${ }^{1}$ & 36 \\
\hline Plant parts per litre $\mathrm{MIN}^{1}$ & 2 \\
\hline Plant parts per litre $\mathrm{MAX}^{1}$ & 189 \\
\hline No. of taxa MODE ${ }^{2}$ & 1 \\
\hline No. of taxa MIN ${ }^{2}$ & 1 \\
\hline No. of taxa $M A X^{2}$ & 4 \\
\hline${ }^{1}$ Based on samples fully sorted $(n=14)$ & \\
\hline $\begin{array}{l}{ }^{2} \text { Based on samples fully sorted }(n=14) \text {; excludes unidentified plant } \\
\text { remains, parenchyma and modern plant parts }\end{array}$ & \\
\hline
\end{tabular}

with the centre of distribution in Southeast Asia (Flora of China). There are several Fimbristylis species reported as weeds of rice in Thailand, and many are found in wetland fields. However, there are also species that occur in upland rice systems. More work will be undertaken to identify the Fimbristylis seeds to species to determine the cultivation practices engaged by the people of Non Ban Jak. Another context (A1 2-9 feature 1) also contained the species Chara zeylanica, a green algae from the Charace al species from the genus Fimbristylis (Figure 40). The genus Fimbristylis is made up of more than 200 species with the centre of distribution in Southeast Asia (Flora of China). There are several Fimbristylis species reported as weeds of rice in Thailand, and many are found in wetland fields. However, there are also species that occur in upland rice systems. More work will be undertaken to identify the Fimbristylis seeds to species to determine the cultivation practices engaged by the people of Non Ban Jak. Another context (A1 2-9 feature 1) also contained the species Chara zeylanica, a green algae from the Characeae family, which is reported as a weed of rice in Thailand particularly in transplanted, dry-seeded and wet-seeded rice (Moody 1989). The weed assemblage from Non Ban Jak is very different from that analysed in Bronze Age 5 Iron Age 1 Ban Non Wat (ca. 790-200 BC), and the Metal Age sites Khao Sam Kaeo and Phu Khao Thong (ca. 400$100 \mathrm{BC}$ ). The main difference lies in the distinct absence of the dryland weed species Acmella paniculata, which is the predominant weed in the above mentioned sites; but also the appearance of a new suite of weeds, including Fimbristylis spp. and Chara zeylanica, which up to now has not been reported in any other site in Thailand.

\section{SUMMARY AND CONCLUSIONS}

The two areas excavated have furnished radiocarbon determinations indicating that Non Ban Jak was a settlement initially occupied during the final phase of the Iron Age in the upper Mun Valley. The opened areas on the eastern and the western mounds have revealed a matching record involving burial within houses, together with industrial activity. The material culture and the mortuary rituals closely match those identified during IA phase 4 at the nearby site of Noen U-Loke. The three or four centuries in question are vital in the transition from prehistory into early historic kingdoms, for it was during this period that inscriptions reveal the establishment of states at, for example Wat Phu, and a military expedition up the Mun Valley led by Citrasena, the future king Mahendravarman (Vickery 1998). Indirect contact with India has a long history in the upper Mun Valley, evidenced in the earliest Iron Age cemetery at Ban Non Wat from at least the $4^{\text {th }}$ century $\mathrm{BC}$ in the form of glass, carnelian and agate jewellery. A most intriguing issue raised by the new evidence for an overlap of at least two centuries between the late prehistoric occupation of Non Ban Jak and the establishment of cities and temples in the lower Mun area at, for example, Kurukșetra (Lorillard 2014). The lack of any evidence, as yet, of further Indian influence in the form of religious motifs, texts, or seals calls into question the degree to which the new states of Chenla penetrated into the late Iron Age communities of the upper Mun Valley. In this context, it is stressed that the final occupation of Non Ban Jak involved pits containing pottery vessels that appear similar in form and finish to those of the Dvaravati states of Central Thailand. These provide a sharp contrast to the predominantly black, burnished ceramic repertoire of the late Iron Age Phimai Black tradition as may be seen in comparing figures 15 and 28 .

The establishment of a new moated settlement late in the Iron Age hints at a growing population, and it is consid- 
ered likely that the initial settlers split away from a long established centre such as Noen U-Loke or Ban Non Wat. One of the missing chapters in the prehistory of the Mun Valley is identifying where people lived. No convincing evidence for domestic dwellings has been encountered at Noen U-Loke or Ban Non Wat. Floors and wall foundations were traced at Non Muang Kao in an identical fashion to those at Non Ban Jak, including lip to lip pots in corners and under floor burials. However, the excavation there uncovered a relatively small area, and no structural plans have been traced (O’Reilly 1998). At Non Ban Jak, however, rooms have been clearly defined, and town lanes have been planned. A fire which destroyed one early building also led to the survival of a kitchen area with cooking vessels in place with large quantities of carbonised rice grains. The quality of construction improved over time, with relatively thin laterite wall foundations being replaced in later stages by thick clay walls aligned with postholes to support the walls. Fragments of daub retaining the impressions of the wattle framework reveal details of wall construction. The floors were made of clay with split timber foundations. Interior baulks of clay might represent furnishings, and postholes within some were most likely to support the roof. Tracing complete house plans, and ultimately town precincts, are for the future.

The functions of individual rooms varied. One was clearly a cooking facility. Others have provided convincing evidence for use in mortuary rituals. Perhaps the clearest, is a late room in the eastern mound measuring 3.8 by $3.8 \mathrm{~m}$, which has at each of the three surviving corners, a lidded pottery vessel. Three graves of an adult, child and infant had been cut through the clay floor. On the western mound, the larger area uncovered has revealed two rows of burials cut through a multi-chambered structure.

Such clearly-defined residential burials have intriguing social implications (White and Eyre 2010, Higham, in press). In their review of house burial, Adams and King (2011) emphasized how interment within houses links the living with the ancestors, and provides the social context for group identity. It reinforces inherited rights to property, wealth and status by the members of the kin group in question. The transition from burial in a ritual location within a settlement to one actually within the house might seem subtle, but as Laneri (2011) has shown for Mesopotamia during the late third and early second millennia B.C., the establishment of house burial took place at a time of marked economic change. Thus, the rise of merchant and entrepreneurial lineages at that juncture involved the formation of powerful households that disposed of increased wealth and social standing. At Titriş Höyük, the development of residential tombs took place as wine production and exchange for exotic valuables enabled competing merchant households gain in social prestige and wealth.

As in Mesopotamia so in the Mun Valley moated sites, the advent of house burials took place at a time of fundamental economic and social changes. Long distance exchange brought carnelian, agate, gold, silver, glass and a massive increase in bronze ornaments. Salt extraction involved numerous production sites. Engineering works saw the construction of multiple banks that surrounded the settlements to capture and reticulate water in moats. Such an endeavour would have involved the marshalling of much labour. This took place at the same time that smiths were forging heavy, socketed iron ploughshares. In Northeast Cambodia, Hawken (2011) has suggested that linear features associated with late Iron Age sites are rice field boundaries. Ban Non Wat incorporated an area at the western edge of the site for corralling domestic water buffalo and cattle.

There is thus a compelling case for the development of an agricultural revolution in the upper Mun Valley that involved ploughing with draft water buffaloes in land improved by access to irrigation if the monsoon rains faltered. Ploughing represents a quantum improvement in efficiency compared with hoeing (Goody 1971) and unlocked the potential for social change based on ownership of improved land. It would also be naïve to suggest that the moats and banks that surrounded the dense concentration of Iron Age sites had no role in defence. This same period witnessed an increase in the manufacture of iron projectile points, one of which, a sharp barbed arrowhead, was found embedded in the spine of one young man interred at Noen U-Loke.

The potential of further excavations at Non Ban Jak is therefore considerable. Many issues deserve greater documentation and investigation. Thus, the incidence of infant mortality, particularly during the first mortuary phase, is unusually high. Detailed palaeopathological analyses that are planned might identify possible causes for this, as would a greater area excavated. For example, it is noted that infants were almost exclusively present in the southwestern part of the western mound, as if an area was reserved for them. The mortuary wealth thus far encountered at Non Ban Jak falls far short of that seen during Iron Age 3 at Noen U-Loke, and was also significantly less than during the contemporary, last mortuary phase at that site. Was this simply a poorer community, perhaps with less involvement in the salt trade? Or might the richer burials of the latest Iron Age be awaiting discovery at Non Ban Jak?

Over a period of three or four centuries, houses were more elaborately constructed. The third mortuary phase in the western mound saw burials grow wealthier, and the offerings placed with the dead reflect a residential group involved in rice cultivation, to judge from the number of sickles, as well as weaving and pottery manufacture. By extending the areas excavated, and opening new investigations on the highest point of the eastern mound, it is considered highly likely that a holy grail of archaeological enquiry in this region might be realised, the residential plan of an Iron Age town. Again, the contrast between those interred in different residences at different times has the potential to document social inequality in the population at a period on the cusp of early state formation. 


\section{ACKNOWLEDGEMENTS}

The excavation of Non Ban Jak was funded by a grant from the Australian Research Council for the programme "From Paddy to Pura: the Origins of Angkor" to Dougald O'Reilly and Louise Shewan. The fieldwork was directed by Charles Higham, Rachanie Thosarat and Nigel Chang. We thank Nathan Harris for working on the human skeletons during the 2014 season and Amphan Kijngam for assisting in identifying the animal bones. We are most grateful to the National Research Council of Thailand and the Fine Arts Department for providing the necessary research permit. Finally, we acknowledge the contribution made by our team of excavators from Ban Non Wat and Ban Nong Khrua Chut for their skill and enthusiasm. We acknowledge with thanks, the valued comments from four reviewers of this article.

\section{AUTHORS}

DO'R and LS conceived the research programme and were awarded the research grant from the Australian Research Council. NC directed the excavations in the eastern part of the 2014 square. FP undertook the radiocarbon determinations and wrote the section on dating. JC wrote the section on the spindle worls. CC reported on the plant remains. SH identified the age and sex of the human remains. The remaining text was written by $\mathrm{CH}$.

\section{REFERENCES}

Adams, R.L. and King S.M. 2011. Residential burial in global perspective. In R.L. Adams and S.M. King eds., Residential Burial: a Multiregional Exploration, pp. 1-16. Archaeological Papers of the American Anthropological Association 20

Bronk Ramsey, C. 2001. Development of the radiocarbon calibration program OxCal. Radiocarbon 43(2A):355-363

Bronk Ramsey, C. 2009a. Bayesian analysis of radiocarbon dates. Radiocarbon 51:337-360.

Bronk Ramsey, C. 2009b. Dealing with outliers and offsets in radiocarbon dating. Radiocarbon 51:1023-1045.

Bronk Ramsey, C., M. Dee, S. Lee, T. Nakagawa and R. Staff. 2010. Developments in the calibration and modelling of radiocarbon dates. Radiocarbon 52(3):953-961.

Cameron, J. 2011. Iron and cloth across the Bay of Bengal: New data from Tha Kae, central Thailand Antiquity 85:559567.

Castillo, C. 2011. Rice in Thailand: the archaeobotanical contribution. Rice 4(3-4):114-120.

Cawte, H.J. and W.E. Boyd 2010. Laterite nodules: a credible source of iron ore in Iron Age Northeast Thailand? Geoarchaeology, 25: 626-644

Flora of China, Vol. 23 Page 200, 飘拂草属 piao fu cao shu, Fimbristylis Vahl, Enum. P1. 2: 285. 1805.

Goody, J. 1971. Technology, Tradition and the State in Africa. Hutchinson: London.

Hawken, S. 2011. Metropolis of Ricefields: a Topographic Classification of a Dispersed Urban Complex. Unpublished Ph.D. dissertation, University of Sydney, Sydney.
Higham, C.F.W. in press. From site formation to social structure in prehistoric Thailand. Journal of Field Archaeology.

Higham, C.F.W., Kijngam, A., and S. Talbot (eds.). 2007. The Origins of the Civilization of Angkor Volume 2: The Excavation of Noen U-Loke and Non Muang Kao. Bangkok: Fine Arts Department of Thailand.

Laneri, N. 2011 A family affair: the use of intramural funerary chambers in Mesopotamia during the later third and early second millennia B.C.E. In R.L. Adams and S.M. King, (eds.), Residential Burial: a Multiregional Exploration Archaeological Papers of the American Anthropological Association 20:121-135.

McGrath, R.J. and W.E. Boyd. 2001. The chronology of the Iron Age 'moats' of northeast Thailand. Antiquity 75:349-360.

Moody, K. 1989. Weeds Reported in Rice in South and Southeast Asia. Los Baños, Laguna: International Rice Research Institute.

O'Reilly, D. 1998. The discovery of clay-lined floors at an Iron Age site in Thailand; preliminary observations from Non Muang Kao, Nakon Ratchasima Province. Journal of the Siam Society 85(1):1-14.

Pryce T.O. and S. Natapintu. 2009. Smelting iron from laterite: technical possibility or ethnographic aberration? Asian Perspectives 48:249-264.

Reimer, P.J., E. Bard, A. Bayliss, J.W. Beck, P.G. Blackwell, C. Bronk Ramsey, C.E. Buck, H. Cheng, R.L. Edwards, M. Friedrich, P.M. Grootes, T.P. Guilderson, H. Haflidason, I. Hajdas, C. Hatté, T.J. Heaton, D.L. Hoffmann, A.G. Hogg, K.A. Hughen, K.F. Kaiser, B. Kromer, S.W. Manning, M. Niu, R.W. Reimer, D.A. Richards, E.M. Scott, J.R. Southon, J.R., Staff, C.S.M. Turney and J. van der Plicht 2013. IntCal13 and Marine13 radiocarbon age calibration curves, 0-50 000 years cal BP. Radiocarbon 55 (4):1869-1887.

Thompson, G.B. 1996. The Excavation of Khok Phanom Di, a Prehistoric Site in Central Thailand. Vol. IV: Subsistence and Environment: the Botanical Evidence (the Biological Remains, part II). London: The Society of Antiquaries of London.

Vickery, M. 1998. Society, Economics and Politics in PreAngkor Cambodia. Tokyo: The Centre for East Asian Cultural Studies for Unesco.

White, J. C., and C. O. Eyre. 2010. Residential burial and the metal age of Thailand, in R. L. Adams and S. M. King, (eds.) Residential Burial: a Multiregional Exploration. Archaeological Papers of the American Anthropological Association 20:59-78. 